\title{
THE IMPACT PERSON-ENVIRONMENT FIT THEORY HAS ON TEACHER RECRUITMENT AND RETENTION
}

A Dissertation
presented to
the Faculty of the Graduate School
at the University of Missouri
In Partial Fulfillment
of the Requirements for the Degree
Doctor of Education
by
AMANDA L. MINEAR
December 2020


(C) Copyright by Amanda Minear, 2020 
The undersigned, appointed by the dean of the Graduate School, have examined the dissertation entitled

\section{THE IMPACT PERSON-ENVIRONMENT FIT THEORY HAS \\ ON TEACHER RECRUITMENT AND RETENTION}

presented by Amanda L. Minear, a candidate for the degree of Doctor of Education, and hereby certify that, in their opinion, it is worthy of acceptance.

Dr. Sandy Hutchinson

Dr. Barbara N. Martin

Dr. Steve Ritter

Dr. Bryan McDonald 


\section{ACKNOWLEDGEMENTS}

When entering this program, we were told that this is a family degree. We were told that many people would make sacrifices to support us while on this journey. There was no way that I could envision how true this would be. With that being said, there are several people I need to thank.

The first thank you goes to my advisor, Dr. Hutchinson. She works tirelessly with doctoral candidates, all while juggling many other projects. Without her, we wouldn't be able to go through this process as smoothly as we have. Thank you, Sandy, for all your love and support along the way.

Others who were in the thick of this program with me deserve a thanks. I especially appreciate Elmer, Lisa, and Jenni who fielded random questions at all hours of the day from me. Your friendship isn't something that I was looking for but would be lost without it now. Last, but certainly not least is Troy. Thank you for always being a voice of reason over the course of our last three degrees. I appreciate you more than you know.

There are several other people who provided support to me during this program. My colleagues from various school districts were instrumental in keeping me excited about my research. To Kristin, who read thousands of words, drove hundreds of miles, and talked on the phone for hours upon end until all my papers were complete. Your love, dedication, and kindness will never be forgotten.

To my parents, Randy and Diana, thank you for instilling a love of learning in me. You sacrificed throughout my entire life to make sure that I had everything I needed to be successful, and for that I will never be able to repay you. You're the best.

A last thank you goes to Dan, my husband. Our house was always a mess, the laundry was never finished, and I had paperwork spread out all over the place, but you never complained. Thank you for being so patient during this process. I couldn't have done this without your support. Thank you. 


\section{TABLE OF CONTENTS}

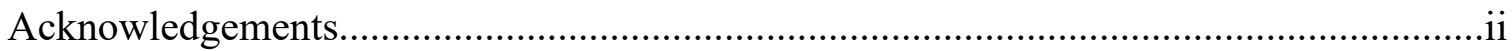

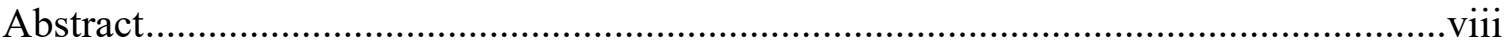

Section One: Introduction to the Dissertation-in-Practice ................................................

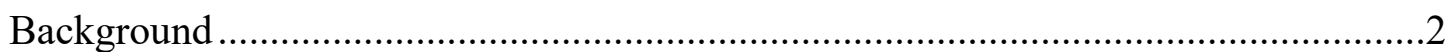

Statement of the Problem...........................................................................................

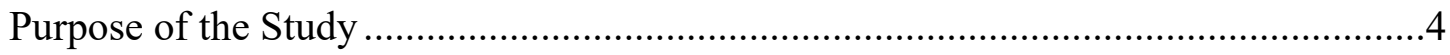

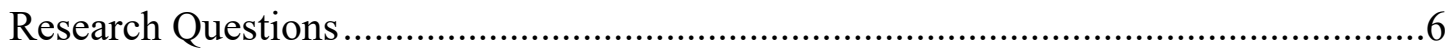

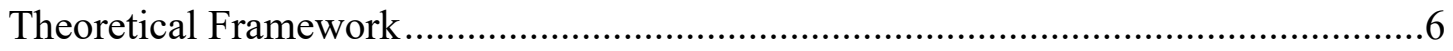

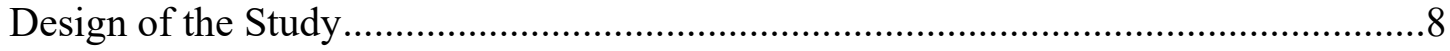

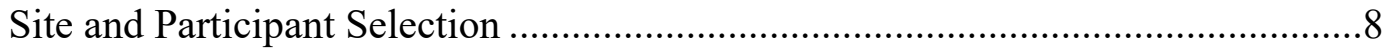

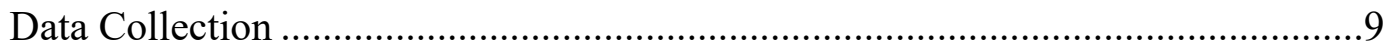

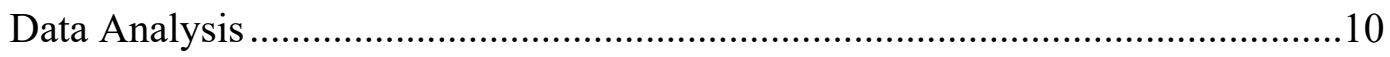

Limitations, Assumptions, and Future Research ................................................. 11

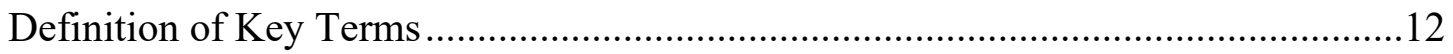

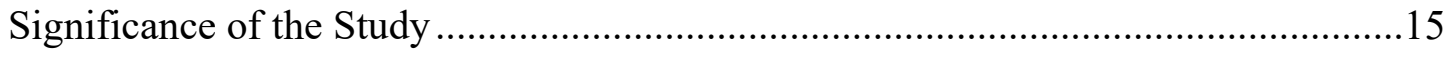

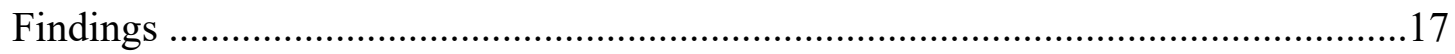

Research Question One: Recruitment........................................................ 17

An untraditional approach............................................................19

In-house programs …....................................................... 19

Reputation ....................................................................... 19

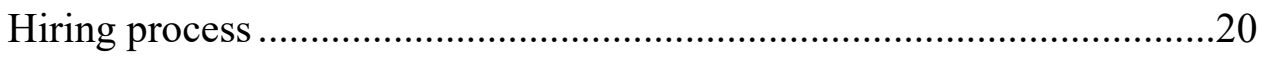

Successful characteristics.................................................21

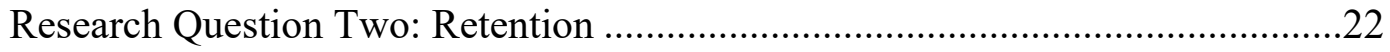

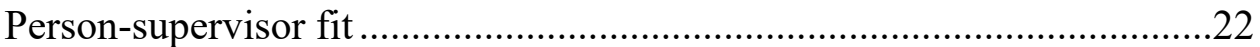


Administration

Person-group fit .24

School-community ............................................................24

Induction programs ......................................................26

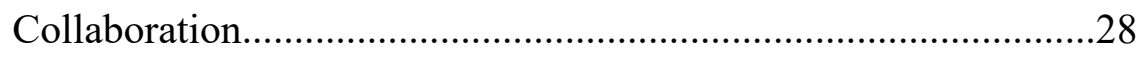

Research Question Three: Long-Term Success ............................................29

Support creates satisfaction...........................................................29

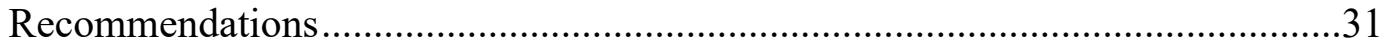

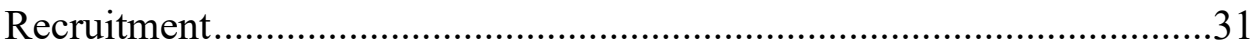

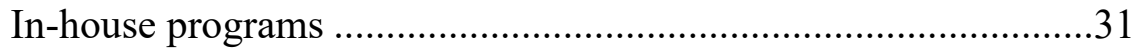

The hiring process ................................................................. 32

Maintaining a positive reputation ............................................34

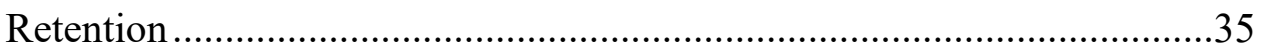

Induction programs ........................................................ 35

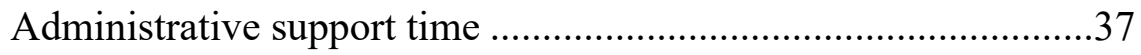

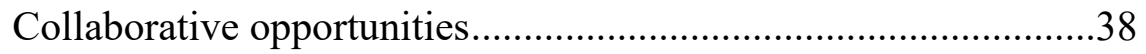

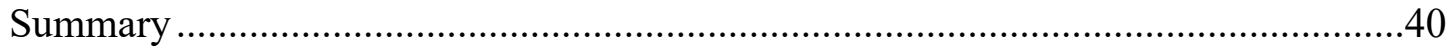

Section Two: Practitioner Setting for the Study .....................................................41

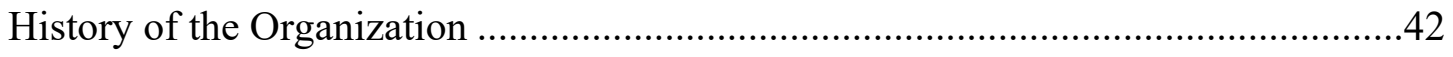

The Structure of Missouri Public Schools .......................................................42

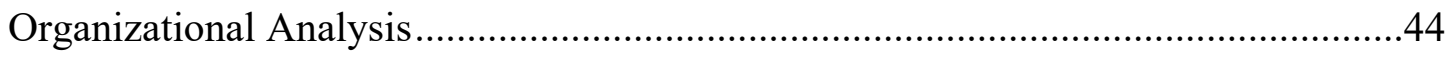

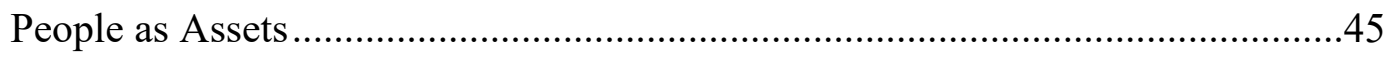

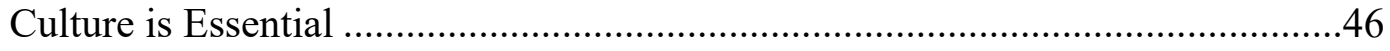

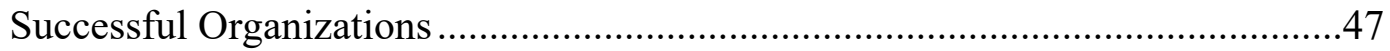

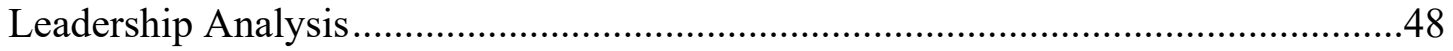


Implications for Research in the Practitioner Setting

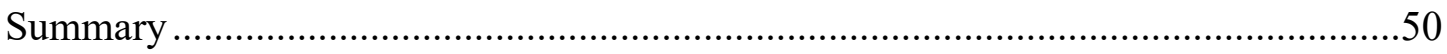

Section Three: Scholarly Review for the Study............................................................51

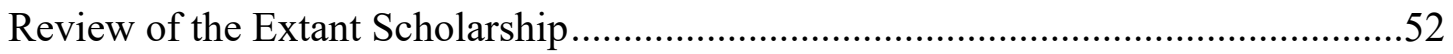

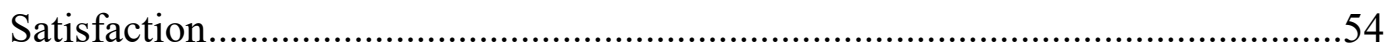

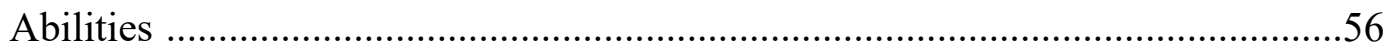

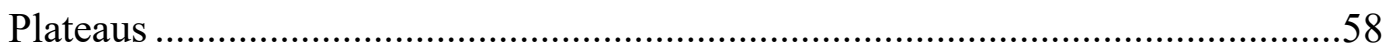

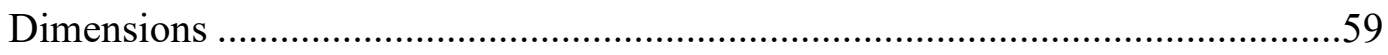

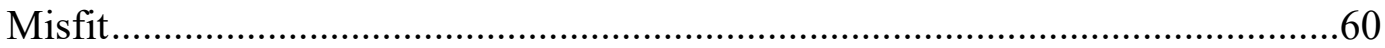

Stress

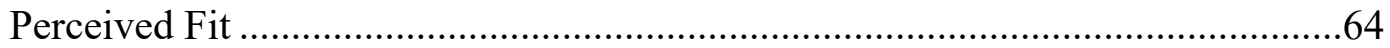

Model of Vocational Personality Types .................................................................65

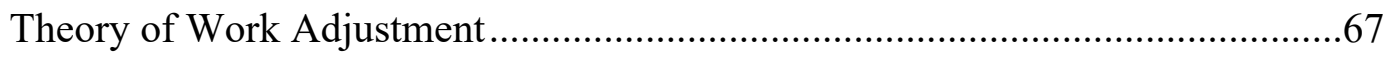

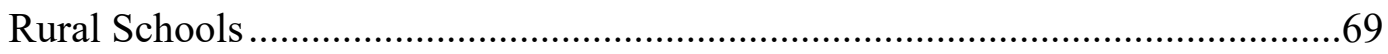

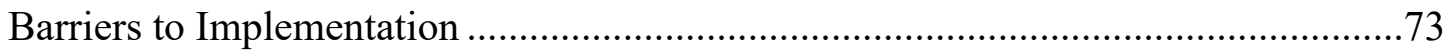

Rethinking Current Practices ...............................................................................

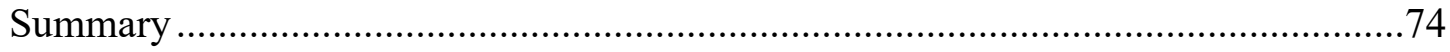

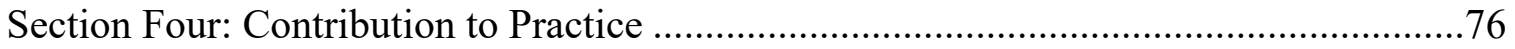

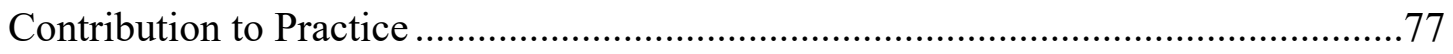

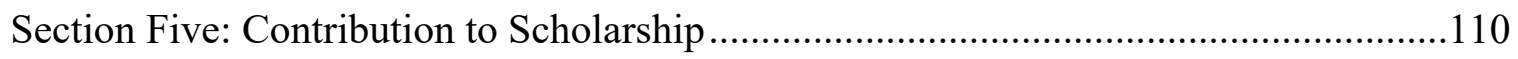

The Impact Satisfaction Has on Teacher Retention in Rural Schools ........................111

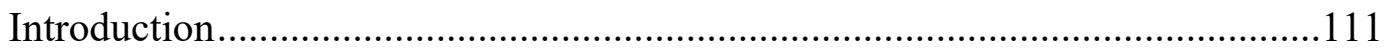

Significance of the Study .............................................................................112

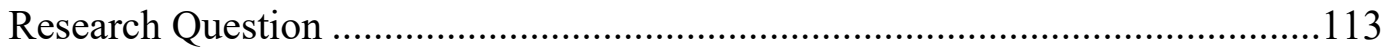

Theoretical Framework ...................................................................................113 
Design of the Study.

Site and Participant Selection .........................................................115

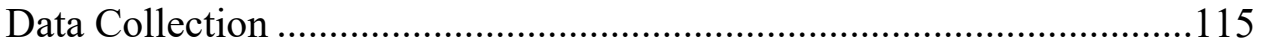

Data Analysis .......................................................................... 116

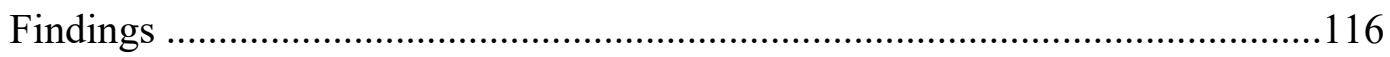

Long-Term Success .............................................................. 116

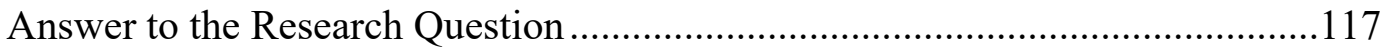

Support Creates Satisfaction ..................................................... 117

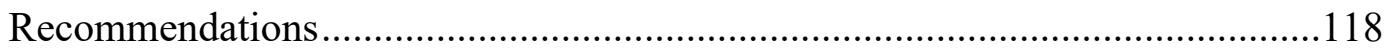

Induction Program ............................................................... 118

Limitations, Assumptions, and Future Research .........................................120

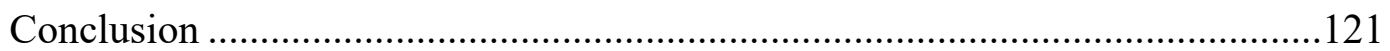

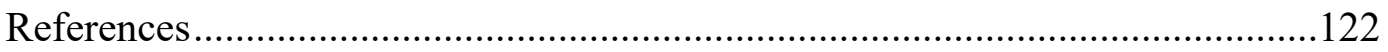

Appendix A: Participants Setting ......................................................... 126

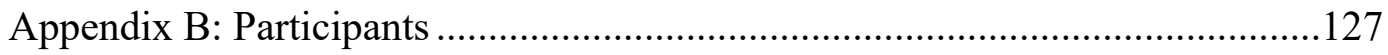

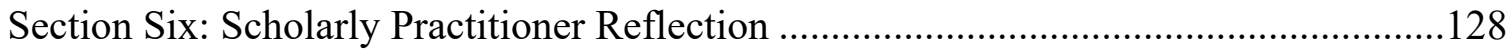

Scholarly Practitioner Reflection ......................................................... 129

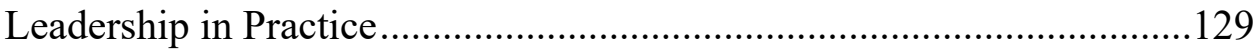

People Focused …................................................................ 130

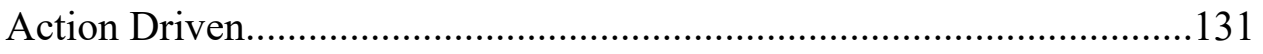

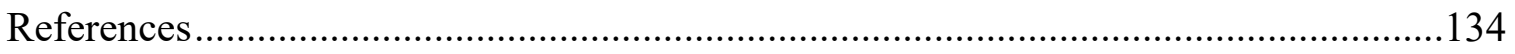

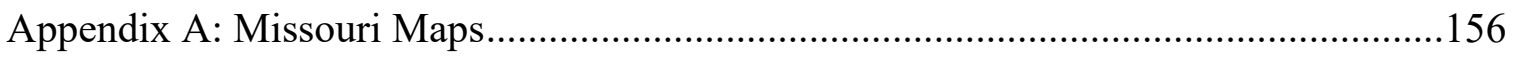

Appendix B: Email Requesting District Participation in Study .................................157

Appendix C: Email Requesting Individual Participation in Study ..............................158

Appendix D: Consent Form to Participate in Study ….............................................159 


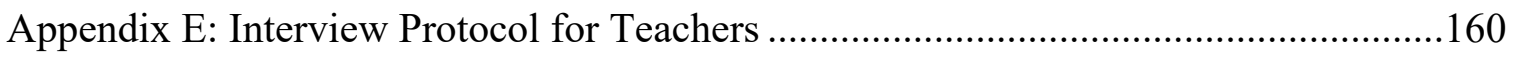

Appendix F: Interview Protocol for Administrators ......................................................161

Appendix G: Research Questions and Corresponding Interview Questions ....................162

Appendix H: Transcript Data Organized by Interview Question Topics ..........................164

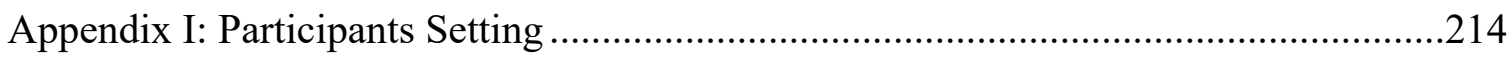

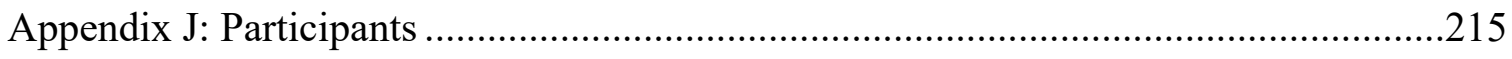

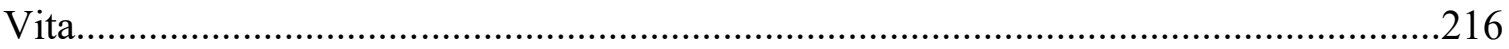




\begin{abstract}
Teacher attrition is negatively impacting the success of students in rural public schools at an unprecedented rate. Using person-environment fit theory as a guide, the perceptions of rural teachers and administrators are shared in this qualitative study. This study makes the connection between satisfaction and the impact the work environment has on it. It analyzes the school-community as a whole and recommends practical solutions to increase retention rates among teachers in rural public schools.
\end{abstract}




\section{SECTION ONE}

INTRODUCTION TO THE DISSERTATION-IN-PRACTICE 


\section{Background}

In 2015, 3.6 million public school teachers moved to a new school the following year; this is the equivalent of replacing one in six teachers for the next school year (Feng, 2017). Podolsky, Kini, Bishop, and Darling-Hammond (2016) found a positive relationship between teaching experience and a variety of other student outcomes, such as reductions in student absences, increases in students' time spent reading for pleasure, and decreases in classroom disruptions. High rates of turnover mean that fewer teachers develop the experience that often leads to compounding academic benefits for their students. (p. 8)

Ultimately, the cost of teacher attrition is significant. It can impact an entire school (Podolsky et al., 2016).

According to Podolsky et al. (2016), teacher turnover is over 50\% higher in schools that teach students living in poverty than in other schools. Recurring teacher shortages are caused by declines in both professionals entering the field of education and the low rates of teacher retention. According to Podolsky et al. (2016), this is especially true in low-income schools. Many of these school districts are finding people to fill their vacancies, but they are not necessarily finding quality individuals. According to Podolsky et al. (2016),

hard-to-staff schools consequently often struggle to attract talented, well-prepared teachers, hiring individuals who have not yet completed (and sometimes have not yet begun) their preparation. Many studies have documented the disproportionate concentration of underprepared and inexperienced teachers in low-income [schools]. (p. 23) 
Not hiring the right people could end in misfit, which is something that appears in most workplaces, according to Wheeler, Gallagher, Brouer, and Sablynski (2007). Misfit occurs when the person and environment lack connection on a variety of levels (Follmer, Talbot, Kristof-Brown, Astrove, \& Billsberry, 2018; Harrison, 2007; Kristof, 1996; Schneider, 1987; Schneider, Goldstein, \& Smith, 1995). "Misfit is generally conceived as the negative end of the fit continuum, and is associated with discomfort or incompatibility" (Follmer et al., 2018, p. 441). Meaningful insight on practices that lead to misfit can be provided by individuals who have experienced it (Billsberry, Ambrosini, Moss-Jones, \& Marsh, 2005; Follmer et al., 2018; Kristof-Brown \& Guay, 2011; Shipp \& Jansen, 2011).

It has been found that employees will often remain in poor fit workplaces, as the decision to leave is complex (Follmer et al, 2018). Often times there is a lack of other opportunities for employees who are in a misfit situation, which causes them to stay (Wheeler et al., 2007). By viewing employees as arbiters of fit, people can manage their fit and reduce negative consequences of misfit (Follmer et al., 2018). Misfit is unpleasant and stressful (Edwards \& Shipp, 2007), causing employees to be motivated to resolve their misfit through turnover (Yu, 2009).

According to Mulvahill (2018), teachers leave their school when it becomes a challenging environment for them to work in. Hard-to-staff schools are often the most under-resourced schools and usually serve the highest number of students living in poverty (Podolsky et al., 2016). In order to make environments like these less challenging for teachers, administrators must recruit teachers who are prepared and have a 
comprehensive approach in place to retain them (Carver-Thomas \& Darling-Hammond, 2017; Podolsky et al., 2016).

\section{Statement of the Problem}

Recent years have raised teacher shortages to a crisis level (Podolsky et al., 2016). The National Center for Education Statistics (1995) stated that schools with the lowest enrollments experience the highest teacher turnover rates. Carver-Thomas and DarlingHammond (2017) reaffirm this in their quantitative study when they state that turnover is "higher for teachers in small schools" (p. vi). Rural schools especially face continual teacher shortages, as they have the highest teacher attrition rate among schools (Ingersoll, 2001; Podolsky et al., 2016).

Teacher attrition has a negative compounding effect on students' academic achievement, as well as a variety of other outcomes (Podolsky et al., 2016). The cost of teacher attrition is noteworthy. Teachers who stay are "much more expert at diagnosing student learning, differentiating instruction to address gaps while accelerating progress, and supporting a range of social, emotional, health, and psychological needs, in addition to sometimes complex academic needs" (Podolsky et al., 2016, p. 21).

\section{Purpose of the Study}

The purpose of this qualitative study is to gain an understanding of the elements of person-environment fit theory and their impact on recruitment and retention in rural public schools. Finding the right fit not only focuses on the individual, but also the organization's characteristics (Georg, 2009). Understanding the connection between both factors could allow organizations to tailor the hiring process rather than using a one-sizefits-all approach (Bohndick, Rosman, Kohlmeyer, \& Buhl, 2018; Vermunt, Richardson, 
Donche, \& Gijbels, 2014). As Podolsky et al. (2016) described, “districts, principals, and teacher-candidates all need quality information to assess the fit between the teacher candidate and the needs of the school. This process is critically important to hiring effective teachers and, therefore, to increasing student learning” (p. 29). Knowing the detrimental consequences that can come with hiring teachers in wrong fit districts, administrators acknowledge that "hiring is hard, and hiring is the single most important thing you can do to improve your school" (Podolsky et al., 2016, p. 29). By accepting the importance of the hiring process in a school's ultimate success, the researcher will determine what constitutes a good fit between rural public schools and prospective teachers that will then lead to increased retention rates.

While there is plenty of research on teacher attrition, there is little information available about how the implementation of the hiring process is related to retention within rural school districts. Each potential teacher has a different experience during the hiring process. Little is known about how that experience influences their fit (Yu, 2009). Ultimately, a suitable fit can increase student achievement (Bohndick et al., 2018; Etzel \& Nagy, 2016; Li, Yao, Chen, \& Wang, 2013) along with teacher satisfaction (Heise, Westermann, Spies, \& Stephan, 1997). The hiring process usually determines if the teacher has the qualifications for the vacant position, but administrators need to determine if the potential teacher is suitable for long-term employment. The individuals' abilities need to match the demands of the organization in order to have a positive effect on academic outcomes (Bohndick et al., 2018; Edwards, Caplan, \& van Harrison, 1998; Edwards \& Shipp, 2007; Reis \& McCoach, 2000). 
According to Heifetz and Laurie (2011), "leaders have to be able to see patterns as if they were on a balcony" (p. 60). Having a seat in the balcony will allow school administrators to see the connections made between teacher-candidates and environments. This will give these district leaders valuable information to use during the hiring process at their school. The pursuit to enhance the hiring process through teacher fit is ambitious in scope and may produce unconventional changes to the current hiring process.

\section{Research Questions}

The researcher will pose three research questions to better understand the connection between people and the environment in which they work:

1. What factors lead administrators to the hiring of a teacher who has successfully worked long-term in a rural school district?

2. What elements of person-environment fit theory appear to be important to retention of teachers in rural public schools?

3. Why do teachers who have successfully worked long-term in a rural school district flourish?

\section{Theoretical Framework}

Caplan's (1987) person-environment fit theory will be used as the theoretical framework for this study. Kristof-Brown, Zimmersonman, and Johnson (2005) stated person-environment fit is "broadly defined as the compatibility between an individual and a work environment that occurs when their characteristics are well matched" ( $p$. 281). There are two ways to look at person-environment fit theory. The first is that "organizations select persons who will best meet the demands of the job" and the second 
is that "prospective employees want to find organizations which make use of their particular abilities and meet their specific needs" (Caplan, 1987, p. 248). It is a supply versus demand theory described initially by French, Rodgers, and Cobb (1974). A poor organizational fit often has a low employee retention rate, according to Caplan (1987). Solutions mentioned include "tailoring the employees' abilities to the demands of the organization" or "altering the organization's resources to meet the needs of the employee" (Caplan, 1987, p. 258).

Within the person-environment fit theory, there are four types of fit: (a) personjob fit, where the fit lies in the individual's cultural values and those that are required to do the actual job; (b) person-organization fit, where those same values match the entire organization; (c) person-group fit, where those values meet those of their specific work group; and (d) person-supervisor fit where those values and those of their manager are the same (Kristof-Brown et al., 2005). There are a number of variables to analyze when considering person-environment fit. Turnover, the most studied variable, is influenced by a variety of fit types (Kristof-Brown et al., 2005). The fit types are all connected to behaviors within a work experience, according to Kristof-Brown et al. (2005). Two types of fit stand out when it comes to recruitment and retention: person-organization and person-job. Both types of fit had strong connections to job satisfaction and organizational commitment (Kristof-Brown et al., 2005). Person-organization fit addresses "the compatibility between people and entire organizations" (Kristof-Brown et al., 2005, p. 285) while person-job fit works with a needs-supplies fit and a demands-ability fit (van Vianen, 2018). Needs-supplies fit has the greatest impact on attitudes and behaviors, while demands-ability fit has an impact on student achievement (Etzel \& Nagy, 2016; Li 
et al., 2013) and teacher satisfaction (Heise et al., 1997). According to Bohndick et al. (2018), demands-ability fit is ideal when the demands of a job match the ability of the individual.

The hiring process was also connected to person-job fit (Kristof-Brown et al., 2005). Kristof-Brown et al. (2005) stated that applicants are recruited based on essential skills of the job and needs of the organization concurrently, but the intent to hire is related more to person-job fit than person-organization fit. This is due to the selection technique being focused on the prerequisites to perform in the workplace (Kristof-Brown et al., 2005).

Overall, person-environment fit assesses characteristics of the work environment and the influences it has on individuals. Through this theoretical framework, "it is clear that fit matters" (Kristof-Brown et al., 2005, p. 315). The better the fit, the more satisfied the individual is at their job (van Vianen, 2018). Person-environment fit has research compiled around Holland's (1997) model of vocational personality types and Dawis and Lofquist's (1984) theory of work adjustment. Both types of seminal research will be discussed further in a following section.

\section{Design of the Study}

\section{Site and Participant Selection}

The researcher used what Merriam and Tisdell (2016) call purposive sampling to select participants, as participants will meet the criteria needed for the study. Five school districts from across the state of Missouri were selected to provide insight for the study. The researcher focused on identifying rural school districts that have a district enrollment under 500 . 
Each Missouri school has a district score card and Missouri School Improvement Program (MSIP) score. District score cards contain a variety of information collected by the Department of Elementary and Secondary Education (DESE). Information on the score cards includes enrollment numbers, the percentage of free and reduced lunch participants, staffing ratios, and salaries. The MSIP assesses five standards. One of those standards is academic achievement (Missouri Department of Elementary and Secondary Education, 2019b). Academic achievement factors in student achievement, as assessed by state testing. Missouri uses the Missouri Assessment Program (MAP) to assess students' academic achievement in three content areas prior to the ninth grade. Both the score card and MSIP are considered part of DESE's accountability system. In this study, each school had an average of 10 or more years of experience from their professional staff as listed on their 2018 DESE report card, and an MSIP score of 90 or higher in 2016. The 2014 and 2015 MSIP scores were also comparable.

After schools were selected, the researcher contacted the school district's superintendent for approval to participate (Appendix B). Once access had been granted, the researcher contacted building administrators to ask for their participation (Appendix B). Once administrators agreed to participate, the researcher asked them to provide names of teachers to participate. Teacher participants worked in the district at least five years and were deemed successful in the classroom by their administration. Teachers were then contacted to participate in the study (Appendix B).

\section{Data Collection}

The researcher was in the role of what Merriam and Tisdell (2016) describe as participant as observer during interviews. This means that the researcher attempted to 
make connections with the participants being studied in order to gain valuable insight. The researcher mainly held what Merriam and Tisdell (2016) call outsider status. Very few relationships were established. The only foreseeable relationship will be with administration for the purpose of support in the areas of recruitment or retention.

Individual interviews were the method used for data collection. Interviews took place during the COVID-19 outbreak, thus causing interviews to be held through an alternative method, called Zoom. All interviews were recorded and transcribed. All data collection followed the University of Missouri's Institutional Review Board ethical requirements.

\section{Data Analysis}

When analyzing the data, the researcher was mindful not to, as Seidman (2013) states, "address the material with a set of hypotheses to test or with a theory developed from another context" (p. 119). The researcher is an administrator in an urban school who graduated from a rural school district in northern Missouri. As an educator, having her own thoughts and opinions about teachers and rural school districts, the researcher was careful to disregard those during data analysis. Merriam and Tisdell (2016) remind the researcher to regularly "think about your biases that you brought into the study" and to be prepared to guard against personal biases (p. 208).

Following Creswell's (2016) steps for the process of coding, the researcher transcribed interviews verbatim. The researcher then read all transcripts and coded each one. Creswell (2016) indicates once all of the codes have been listed, they can then be put into groups "to eliminate redundancy and overlap" (p. 162). Once themes emerged in the coding process, the researcher determined the themes most beneficial for answering the 
research questions. Themes and sub-themes are addressed in the findings. Patterns that emerge will validate the findings of a qualitative study (Merriam \& Tisdell, 2016).

\section{Limitations, Assumptions, and Future Research}

There are several limitations to this study. To begin with, this study included only five schools all from the state of Missouri. Ideally, more rural districts would have been used and data could have been collected from other states. Another aspect that limits the study is that each building administrator was not necessarily the one to hire the successful teacher. It would have been ideal to expand the study to include only schools where the current building administrator was at the school when the vacancy was open. They would have more insight on what characteristics they initially saw in the candidate and ultimately why they hired them. This would also allow the administrator to discuss qualities that lead the teacher to continue to see success in their school.

Even though the researcher is considered an outsider, Markham and Buchanan (2012) acknowledged that scholarly practitioners will have ethical issues arise when researching. The researcher was mindful of the role reflexivity could have in this study. Reflexivity is understanding the impact our background and experiences have on shaping the interpretation of the data being collected. This means that evaluating bias must be a priority (Creswell, 2014). A few simple steps used to avoid conflicts of interest were to balance the rights of participants and benefits of the study (Markham \& Buchanan, 2012), follow professional codes of ethics, such as those approved by the American Educational Research Association Council, and use self-reflection to eliminate bias from the study (Merriam \& Tisdell, 2016). The researcher consulted professionals in each stage of work, as Creswell (2014) suggests, to ensure ethical issues were not impacting the study. To 
add validity, a peer debriefer was used to review the interpretations of the data. This adds validity to the study, according to Creswell (2014). The researcher also used her program advisor as an external auditor to increase the validity of the study.

A couple future research opportunities arose during this study. Many teacher participants discussed principals they used to work for in the district they are currently working in. While this study looks at the environment as a whole supports the teacher, it would be interesting to see the impact administrator retention has on retention of teachers in rural schools. Rural schools are considered a hard-to-staff school along with urban schools. Completing this study with urban schools and then comparing the results might help states such as Missouri update their teacher preparation or administrator certificate programs to better prepare staff to go into one of the two school settings.

\section{Definition of Key Terms}

For the purpose of this study, the following terms will be defined.

Administrator: Public school administrators are principals within their buildings. They are the instructional leaders for their schools. They support teachers to help them meet state educational standards and school improvement plan objectives.

Annual Progress Report (APR): An Annual Progress Report provides school districts a snapshot of their student achievement. This is included on the report card.

Board of Education: A Board of Education in a Missouri public school is comprised of seven elected members who meet monthly to discuss various aspects of school. They create and revise policies, review budget items, support facility growth, as well as attend to personnel matters. They employ the superintendent of schools but are advised by him or her during their decision-making process. 


\section{Department of Elementary and Secondary Education (DESE): The}

Department of Elementary and Secondary Education falls under the State Board of Education. It is an agency that works to regulate public schools in the state of Missouri.

Elementary: Most elementary schools host first through fifth grades. Some schools can include sixth, seventh, or eighth grades. Most buildings also host kindergarten, while some schools also offer pre-school programs.

End of Course (EOC): High school students take assessments called End of Course examinations in nine courses. This is part of the Missouri Assessment Program (MAP) assesses student achievement in English I and II, algebra I and II, geometry, American history, government, biology, and physical science.

Fit: Fit refers to teachers finding a school district that provides an environment for them to be a long-term teacher and a teacher providing the school with successful teaching of their students.

Hard-to-Staff Schools: Schools that struggle to retain talented teachers due to their location or salaries. These schools often lack amenities that other districts can offer to attract teachers. Often a majority of their students live in poverty and perform below grade level on state assessments. Low enrollment hard-to-staff schools are rural while high enrollment hard-to-staff schools are urban.

High School: Most high schools house ninth through twelfth grades. Some schools can include seventh or eighth grades. By Missouri state law, students may attend school until the age of 21 .

Middle School: Adolescents attend middle school. Middle schools usually host six, seventh, and eighth grades. Some middle schools can include fifth or ninth grades. 
Misfit: Misfit refers to teachers and school districts not be compatible. The environment may not be desirable to the teacher or the teacher may not meet the needs of the school.

Missouri Assessment Program (MAP): The Missouri Assessment Program is used to provide data for the areas of achievement on the Missouri School Improvement Program (MSIP). The MAP assesses students in mathematics and English language arts in elementary and middle school. Science is also assessed in fifth and eighth grades.

Missouri's Instructional Networked Teaching Strategies (eMINTS): This is a program put on by the University of Missouri with the mission of training teachers to teach using a combination of technology and research-based strategies. Trainers provide high-quality and innovative professional development to help teachers increase their effectiveness.

Missouri's Partnership for Educational Renewal (MPER): A partnership between the University of Missouri and 22 school districts in the state of Missouri. This program places pre-service teachers in classrooms to get real-world experience.

Missouri School Improvement Program (MSIP): An accountability system by the Department of Elementary and Secondary Education in Missouri. Each school district in the state of Missouri is assessed by five standards: (1) academic achievement, (2) subgroup achievement, (3) college and career readiness, (4) attendance, and (5) graduation rate.

Recruitment: The process to increase the number of applications of highly qualified teachers willing to accept a position in the school district.

Report Card: This is an online reporting tool. This provides the public with 
information such as the years of experience, the district enrollment, and the percentage of student eligible for free or reduced price lunch.

Retention: The ability to reduce teacher attrition within one school district while increasing stability in the learning environment.

Rural: All territory, population, and housing units located outside of urbanized areas and urban clusters.

Score Card: The score card is considered an accountability system. It contains the MSIP information collected by DESE.

Superintendent: This school official is the top executive for the district. The superintendent leads initiatives that directly impact district goals, works closely with administrators to support teachers, and supervises day-to-day decisions for the school district, among a variety of other things.

Teaching Fellows: A nationally recognized one-year graduate program put on by the University of Missouri. The program provides first year teachers an opportunity to complete their master's degree under the guidance of a full-time mentor teacher. The program is no longer offered.

\section{Significance of the Study}

"One of the most pressing issues facing policymakers is how to staff classrooms with a stable teaching force responsive to complex student needs and the growing demands of the knowledge economy" (Podolsky et al., 2016, p. 1). Current trends, according to Podolsky et al. (2016), show the demand for teachers rising while the supply of them is diminishing. This, along with teachers leaving the profession, provides concern for the future of students. School leaders need a better understanding of why 
teachers leave the profession, as it is critical to improving student achievement (Podolsky et al., 2016).

Hong (2010) agreed that teacher turnover is an ongoing concern. It negatively impacts student achievement, as well as has psychological consequences on students (Ronfeldt, Loeb, \& Wyckoff, 2013). Vekeman, Devos, Valcke, and Rosseel (2018) identified a variety of antecedents leading to turnover. These include human resource practices (TALIS, 2008), student demographics, teacher characteristics, and working conditions (Borman \& Dowling, 2008; Vekeman et al., 2018), and teacher fit within the organization (Youngs, Pogodzinski, Grogan, \& Perrone, 2015).

Researchers agree that employee fit can make an impact at the workplace. This is no different for teachers in rural school districts. Finding a suitable fit can provide complex work-related outcomes (Arthur, Bell, Villado, \& Doverspike, 2006; Chatman, 1989; French, Rogers, \& Cobb, 1974; Murry, 1938). Teachers who fit their districts have less stress, more trust, better team cohesion, and higher job satisfaction while the organization sees less withdrawal and turnover, along with better performance (Harold, Oh, Holtz, Han, \& Giacalone, 2016; Kristof-Brown et al., 2005; Mulki, Jaramillo, \& Locander, 2006; Naus, Van Iterson, \& Roe, 2007; Oh, Guay, Kim, Harold, Lee, Heo, \& Shin, 2014). There is a substantial weight placed on administrators to hire the right people to teach in their schools.

Understanding the importance fit has for recruitment and retention of teachers means that administrators must find connections with the right individual during the hiring process. As discussed earlier, an individual's abilities should meet the needs of the organization. If the individual's abilities exceed the demands of the organization, there 
could be negative effects in motivation. This could mean refining the experience potential hires have during the hiring process. The organization may need to tailor the environment to match the individual's abilities (Bohndick et al., 2018; Edwards et al., 1998; Edwards \& Shipp, 2007). One thing that can be used to personalize an individual's experience is professional development (Johnson, Birkeland, Kardos, Kauffman, Liu, \& Peske, 2001; TALIS, 2008), which can be a precursor to teacher attraction and retention (Johnson et al., 2001), classroom performance (Desimone, Porter, Garet, Yoon, \& Birman, 2002), and job satisfaction (Shen, Leslie, Spybrook, \& Ma, 2012).

\section{Findings}

After analysis of the transcripts, multiple themes emerged. The themes addressed the three research questions. Each participant shared with the researcher their journey to teaching in a rural public school and why they have stayed long-term. There was an overwhelming theme of connection in all areas of recruitment and retention. Many teacher participants had a connection to the job itself while going through the recruitment process, and almost all teacher participants felt connected to the school-community as a whole to stay in the position as long as they have.

\section{Research Question One: Recruitment}

The first research question asked what factors lead administrators to the hiring of a teacher who has successfully worked long-term in a rural school district. Many participants were connected to someone in their current school that helped them get their position. The connections widely varied. Some had family members already working in the district while others had been working there part-time already. No matter what that 
looked like, many participants attributed that connection as to the reason why they ended up working at the school they are in.

Elena from Easton said, "mine was quite different than probably most peoples." She got a call from her husband's cousin who was the principal, "he said I need you here." James's hiring process was also different than most. He joked that he "never actually interviewed for this job." James was filling in for the agriculture education teacher at Joanstown when the superintendent came to him and said, "the job is yours if you want it."

Jacob and Julia both knew the hiring administrator when they applied for their jobs. Jacob stumbled upon a former teacher of his from high school who was now the principal at Joanstown. He was looking for a high school social studies teacher and, luckily, Jacob was a social studies education major. Jacob was in the right place at the right time. Time was also on Nina's side. She was a college senior when she was asked to apply for the University of Missouri's graduate program called MU Teaching Fellows by the principal that would later hire her. "I think I just kind of slid into my spot," she said. Nina said that New Falls had an opening when she would have needed to start looking for a full-time teaching position and her principal told her that they were going to hire her for it. "I lucked out. I graduated at the right time."

Teachers consider many factors when it comes to applying for a position in a rural area. Small schools can offer perks that other, larger schools cannot. Many teachers mentioned small class sizes, a lack of extra duties, and time to collaborate as positives in their current school. Melissa really looked forward to having time to collaborate with other teachers specifically at Marshall City. Not many rural schools offer team time for 
their staff. "I was most excited about and been most fulfilled by being part of a team and that community we have created," Melissa said. Stability of the school itself was another topic that was frequently mentioned. Julia and Matt were both looking for a long-term position when they applied to their current school. Joanstown had a low turnover rate, while Marshall City is stable enough to not have to consider consolidating with other surrounding schools. Also, Matt shared that "having administrators that have been there long term was enormous.”

An untraditional approach. Official recruitment efforts look different across each rural school that was used in the study. Some schools have a traditional approach where they use websites to post their vacancies. Most principals mentioned using MO Teaching Jobs as their primary choice. A couple of the school's attend job fairs at local universities as a way to meet potential hires. Other schools use more creative methods.

In-house programs. Successful rural districts use in-house programs to recruit prospective teachers. Some districts heavily rely on programs like Cadet Teaching, A+ Tutoring, and Future Teachers of America to encourage their own high school students to become teachers and then come back to their schools to teach. Natalie, the principal from New Falls, said she personally works with their high school cadet teachers who "have a natural ability to connect" with children. She believes that it helps high school students see their potential as a future teacher. Ethan said that he also encourages his high school students to come back to Easton to teach. "We try to recruit a lot of our own people," he shared.

Reputation. Outside of websites, job fairs, and in-house programs, administrators shared that their school's reputation is what brings in new teachers. It is all about 
connections to surrounding areas, participants confirmed. Principals shared that word of mouth is often what fills their vacancies. Joel said that they "rely on staff to be advocates for Joanstown...Talking to others in our profession really helps us out.” Most teachers agreed that it was what they heard about the school that ultimately made them apply. Mya shared that "Marshall City had a really good reputation. You would hear about them receiving different academic awards, how good they were in sports, and amazing things about their teachers and administrators." She said teachers, community members, and parents always shared the same message. She knew that "if I ever had the privilege of working there, with such a high reputation, I would take the opportunity."

The hiring process. The hiring process brought up a unique kind of connection in this study. In most cases, teachers were interviewed in an intimate setting. Cooper said they try to have a very personal approach to hiring in Coalsville. "We walk around the whole campus and just talk to get to know them." Cooper prefers to do this during the school day so that applicants can see the kids learning. "They can actually see the true day-to-day operations, not just an empty school building." Ethan said it is more important to "get a feel for what that person knows and how they will fit into what we're trying to do" rather than just asking them a bunch of questions. Joel's approach to hiring is similar to Ethan's. He looks for people who "have a lot of energy and are willing to do a lot of different things...someone who is approachable, sensible, and will fit into [the schoolcommunity]."

Administrators with this approach agreed that they felt successful in hiring long term teachers. Mark shared he has only had to hire six teachers in the last eight years. Ethan said they also try to get a feel for the applicant's future plans. He said he prioritizes 
people they think will stick around. "I don't want to be interviewing someone next year for that [same] job." Joel shared they really try to prioritize the applicant's values. Will "their character mesh well with the community?" Joanstown administrators want their team of teachers to be "a cohesive unit," like most other schools interviewed.

Jana shared what the process looked like for her as a teacher. She met with the superintendent at Joanstown when she was interviewing for her position. Her interview process "was pretty laid back." He asked her to just come in and talk with him. "It didn’t feel like it was that much of an interview. It was more of a discussion." Jana said it "felt like a good place to be, so there wasn't a lot of thinking. I just said yes and kind of jumped on board." We ended up meeting at a local restaurant to discuss what the teaching schedule would look like.

Successful characteristics. While hiring, it may be important to look for some specific characteristics to know if teachers are going to be successful long-term in a small rural school. Most of the teachers interviewed have some traits in common. The traits most mentioned were personability and growth. Administrators felt like new teachers who had these traits were more successful than others. They believed that those traits fueled their teacher's passion for the profession.

Nicole "doesn't like things to get stale," stating she is constantly reaching out for new ideas to incorporate into her classroom. All administrators also agreed that their most successful teachers look for opportunities to grow in their field. Joel said he looks for teacher who "are constantly looking for ways to improve their craft." Natalie agreed that her teachers have an unmatched "drive to improve...they have a willingness and ability 
to want to learn new things. They don't want to be stagnant and realize that things are changing. They are able to embrace that and still teach at a high level."

Teachers in rural schools often work to get to know their students on a personal level. James and Jacob shared that their classes are very conversational. This helps them make students feel comfortable in their classes. Caleb said he cares for his students. "I care sometimes too much." He talked about how that impacts his students. He said, "believe it or not, those little rascals know when you care." Natalie said that her teachers are always going above and beyond for their students. "They work the extra time with not expecting anything extra." Ethan and Joel agreed that compassion played a big part in their teachers' success. Joel noted that his teachers "connect well with our students. They connect well with our community."

\section{Research Question Two: Retention}

The second research question asked what elements of person-environment fit theory appear to be important to retention of teachers in rural public schools. There are four types of fit that fall under person-environment fit theory: job, organization, group, and supervisor. While the literature shared how important person-job fit and personorganization fit are for overall retention rates, the researcher found that person-supervisor fit and person-group fit may be more impactful than originally believed. It appears that supervisors and groups are what comprise the environment that determine if teachers want to stay or leave. Curt discussed the difference between his first year at a large school and his second year at a small school. "Ultimately, [my administration] is why I am here. It is the people that are actually trying to help you succeed...That's a huge thing." 
Person-supervisor fit. Often times environments reflect the values of their managers. The participants of this study show the kind of impact environment can make on their decision to stay or leave. In the rural school setting, teachers have shown they want to connect not only to their principal, but also to their superintendent. Teachers look to both for guidance and support throughout each school year.

Administration. When asked about their connections with administration past and present, teachers had much to say. Most connections start from the very beginning. Melissa said her principal was in charge of the teacher induction program at Marshall City. Her principal "went through everything with us." She appreciated how thorough she was in her presentation. Elena feels like her principal is just as supportive year-round. She often hears how much he appreciates the work the teachers in the building are doing. "What can I do to support you?" is often a phrase he asks the staff.

Mya shared that her principal also checks in often. They make sure that they are on the same page. 'I'm glad that I have the opportunity to [communicate frequently] because I feel like I can speak freely with her.” Many teacher participants had a leadership role in their building. Nora, for example, works on various committees. She said that her principal "always asks what we think. She wants to hear from us." Julia and Cara also mentioned working closely with their administration. For them, it is because of the programs they run at their school.

Caleb feels fortunate to have the support of his administration. He shared that he "got lucky. I am in a small school that cares. My principal, she loves me. We get along great." Not only does he get along with his principal, but also his superintendent. Caleb said that he is "completely empathic and understanding. He likes to listen... He likes to 
hear people's input. And that's huge for me." Caleb also likes when his principal asks for his opinions on decisions, too. He said that is just a small piece of why he "loves his administration.”

The support from principals is never ending in a place like Marshall City. Melissa shared how many times she felt overwhelmed by the work load she had as a teacher in a small school. She said that many nights her principal would have to tell her to go home. She even went so far as "buying a writing program that would give kids automatic feedback just to help alleviate some of my work.” That may seem like a small gesture, but it has stuck with Melissa for many years. "I had a stellar, stellar principal. I would not be the teacher that I am without her...she has her hand in every part of [what I did] and it was guiding and supporting the entire way."

The principals who were interviewed had an interesting perception on their relationship with teachers. Natalie said the administrators at New Falls like to take their new teachers out to lunch. She said it allows them to "build rapport with them [new teachers.]" Mark keeps his door open for questions. Time to talk is important to him. He thinks "it builds relationship and comfort" with new teachers.

Person-group fit. Groups can look widely diverse depending on the situation. In this study, a group could mean a grade level partner, a professional learning community, a committee, or even members from the community. It was obvious that no matter how the group is classified, it determined how connected to the school participants felt. Jacob provides a perfect example of what many participants shared when asked what keeps them at their current school. Jacob and his wife both work at Joanstown now. He said they brought their kids to the school with them because they enjoy the school-community 
so much. 'It's a family affair. And that's because we grew to love the town, the school, everything about it."

School-community. Many participants believe that the community is the reason why the school has been so successful for so long. When Mya got to Marshall City, she had "never seen so much community support, whether it's from churches or local businesses. Organizations just reach out to you." Matt shared how the trickle-down effect works in their school-community. The school board "supports the administration and the administration backs the teachers." He said this is "one of the reasons that I've stayed as long as I have.”

Curt felt the power of the community as soon as he was driving into town for his interview. "I was in an unfamiliar car and there was someone who waved at me. That was my first experience in Coalsville." Elena agreed that there is a great deal of community involvement beyond the classroom. "This is the fourth different school [I've worked at] and I'd say it's the weirdest school I've ever taught in. The community here within the school and the community itself is very family based." When asked how to get connected to the community, Mark thinks the biggest way is to just be visible. "That's how you build relationships." Marshall City's "community has a tremendous amount of support," according to Mark.

Cara said the Coalsville community is very positive, as a whole. "Everybody's here to help each other out...Because we are so small, everybody just pulls together." Schools like Coalsville feel "like a different world." Caleb said Coalsville is the kind of place where if you need flour, your neighbor would give you some. Curt shared that "another thing I value about Coalsville is that...the community values the school." 
"Our school's really all that [our community] has," according to Cooper. He loves seeing everyone come together whether it is at a ball game or another school event. The stands are "packed. It's always packed... We have plenty of people that show up, so it's a good dynamic." Curt feels like the community has to be this way or it "would be shuttered." He wrapped up by discussing how many other districts have been consolidated around them. Cara agreed. She stated the school is "the heart of the town." James feels like teachers support each other and the community is very active in school activities. "We have great community support." Natalie shared that New Falls likes to keep the community involved because they are so supportive. They like to bring in parents to read to classes or help make copies for the teachers. Joel said his teachers "just have to be grounded" because that's how the community is.

"The thing that sticks out above all else is the community support behind the school. The school drives the community and the community throws it's full weight behind the school," Matt said. Joel feels the same way. He furthered his thoughts by saying, "our community is just outstanding. It's a great support system...It's one of the reasons I think our [school] has been so successful.”

Induction programs. Participants shared what kind of impact their colleagues had on them when they were new to their schools. Many interactions were first encouraged by the teacher induction programs set up at each school. Joel said they have an induction program he thinks is "really important. It shows the new teachers the Joanstown community. It takes them around to some small businesses and lets them get to know the parents." He said that giving his new teachers a visual of the community they are serving 
helps prepare them for the start of school. Many districts believe that bridging the gap between the school and community is part of their duty to new teachers.

Mya said she thinks mentoring is a necessary component for new teachers to be successful. "Training, orientation, and mentorship, they are just so crucial to the induction process. [It helps] you get to know everything." Each building assigns mentors in different ways. At Coalsville, they try to pair up teachers by "content area or grade level," while Natalie likes to pair people up who normally would not work together on a daily basis at New Falls. She feels like it provides new teachers "an out" if they have "some kind of conflict." Mark also mentioned a mentoring program. He said they like to pair new teachers up with a mentor in their same grade level at Marshall City. He called this a horizontal mentor, but he also mentioned they like to provide a vertical mentor for curriculum purposes. That way, "we have at least a couple of individuals that are meeting with them regularly to try to give them support." Cooper discussed how important those mentors are. He said, "making sure that they're paired with teachers that have been here for a while, so they know how we do things."

Natalie said that while they have the program designed for the new teacher to meet with their mentor at specific times, "most of them are meeting more frequently." Jacob discussed working with his mentor at Joanstown when he started. He said, "it wasn't very formal with him, which was awesome for me because I'm kind of laid back. We just had conversations and hung out through that process." Jacob liked that he really got a "feel for how to get things done."

Being thoughtful with the mentoring process is important. Melissa appreciated that she had easy access to her mentor. They shared a common plan time and met weekly 
with their team. She said her mentor "was fantastic...she was just really supportive and I think we had really good chemistry together where our personalities just really worked well... She was always available for me to just pop in and ask a question." Melissa joked about how her mentor never got annoyed with her. "I really don't know how because I had a lot of questions that first year."

Collaboration. Besides having a mentor, Julia said that she also had extra professional development when she started in Joanstown. Many participants mentioned how much they appreciated the extra professional development that was provided to them as new teachers. Natalie thinks the professional development piece is very important. She has a committee she works with to specifically support new teachers. She said it provides them with "the nuts and bolts of what they need to be able to do." Cooper also likes to offer professional development opportunities to his new teachers. He likes to "bring in subs and then send our younger teachers to different schools." He believes his teachers really enjoy that.

All the schools in the study provided significant time not only outside of school to collaborate, but also during school hours. Natalie stated some of her teachers have common plan time at New Falls. She thinks this is especially "beneficial when you have new teachers because it's not like you're just going in there by yourself trying to figure it out." Matt said his team meets once a week. During their plan period they "go over kids that we think are at risk. We go over data, not only grades, but also how many kids have absences that week. And also, behavior...who needs a mentor, who needs extra help.” Matt feels like there is constant communication between his teammates. Nina also appreciates that she has a common plan time to meet with other teachers. Her school uses 
a needs assessment to drive collaboration. That makes her feel like her voice is heard. “It's not like a stadium and you've got all these faces and you're not really sure who's saying what or whose idea it was. If we have an idea, it's listened to."

Not all teachers are able to have a common plan time built into their schedule. In that case, many schools like to collaborate with each other. Natalie said they send teachers to other schools who "we've heard are successful and have good programs...it gives [our teachers] some insight and it's new scenery for them to get new ideas." Joanstown collaborates with conference schools at the beginning of the year. "All the principals and superintendents come up with a lot of the topics that are going to be covered there, but we also take teacher input from the year before."

Using teachers as leaders is also beneficial. Mark said he also likes to utilize his teachers' strengths during their professional development time if it is relevant. For example, he has one teacher who leads their technology work in Marshall City. "She's really good about providing professional development to our staff, as a whole, on inservice days...she's good about showing teachers new things or different things to try in the classroom."

\section{Research Question Three: Long-Term Success}

The third research question asked why do teachers who have successfully worked long-term in a rural school district flourish. In order to know why teachers stay longterm, we need to know what keeps them satisfied. Some participants suggested that successful teachers aren't ever completely satisfied, that they are often always looking for opportunities to grow. While, in a sense, this may be true, many participants shared in detail what keeps them at satisfied with their current school. 
Support creates satisfaction. Almost every participant stated that support is a main factor in their success. Caleb believes "it all starts with administration." Nora confirmed that when her administrators are supportive, she is the most satisfied. Her administrators support her at times when she has questions or student issues. Many teachers feel like they can share concerns with their administrators. According to Nora, teachers want to know that "their ideas matter."

Mark, a principal at Marshall City, agreed. He has no doubt that being supported is going to keep his teachers satisfied. Cooper also believes it boils down to support. Teachers "need to feel like, at the end of the day, they can teach and do what's best, and they're going to have administrator support, no matter what." He believes that his role as the principal is to "be the person that teachers can count on, that's going to be here for you."

It's also important for administration to know when teachers aren't satisfied, so some teachers described that. Cara said that people "definitely know if [teachers] aren't satisfied." Julia and Elena confirmed this. Julia shared that you can actually hear the difference between a satisfied and an unsatisfied staff. Elena thinks you know if people are satisfied by just visiting with them. When teachers aren't happy, they talk about anything and everything that upsets them. Julia believes that you can tell that the staff is satisfied when "the kids seem happy. When the staff is happy, it usually translates to them."

Ultimately, teacher participants confirmed that if they are unsatisfied that they would be looking for a new school to work at. Nina also said that she knows New Falls is a good fit for her because she is happy. "I haven't really wanted to go somewhere else. 
Matt feels similarly. He said the teacher retention lets you know if teachers are satisfied. In Marshall City, the people Matt is close with has extremely high satisfaction. They are not looking for other jobs. Mark understands that. “If [teachers] don't feel like they're getting supported by the administration, they're not going to want to be here."

\section{Recommendations}

\section{Recruitment}

In-house programs. While it is important to look for characteristics of successful teachers when interviewing candidates during the hiring process, it became obvious that in-house programs are one of the best ways to recruit the most qualified candidates who are likely to stay long-term. Many successful districts use programs like Cadet Teaching, A+, and Future Teachers of America to see the potential their own high school students have to become teachers.

"We try to recruit a lot of our own people," said Ethan. Ethan believes that their school district does a great job of "encouraging our students to come back and teach." $\mathrm{He}$ watches the interactions high school students have with the younger children. He feels like he knows which high school student would make a good teacher in their district.

Principals play a large role in this piece of recruitment. Natalie said that she personally works with the high school cadet teachers in New Falls. She encourages those that "have a natural ability to connect" to go into the field of education and then return to their community once they graduate college. Natalie believes that this process has helped high school students realize that they want to become a teacher.

Several teachers mentioned that in-house programs are why they decided to become teachers. Nina shared that she was a cadet teacher in high school. She said that 
her principal stayed in contact with her while she was in college in hopes that she could convince her to return to the district as a teacher. Nina was encouraged to get connected to a university internship program that allowed her to get her masters while working back in her hometown.

The hiring process. Most administrators feel like Ethan does when he said he does not want to be interviewing people for the same position over and over again. In order to not have to hire for the same position year-after-year, administrators need to have an idea of what candidates will be successful long-term in a rural school district. Taking a personal approach to hiring might be the first step.

Having a preview of the job can help candidates see what the expectations look like, but it can also provide insight for administrators. Most administrators said they preferred to interview candidates during the school day. This way candidates can see the kids learning. "They can actually see the true day to day operations, not just an empty school building." Many administrators found that doing so during the day helps shed light on the candidate's ability to interact with others.

Many participants shared that they had laid back interviews when they got hired. This is mainly due to the fact that many of the successful long-term teachers had experience in a rural school. Some participants attended a rural school growing up, while others may have married into a family that had a connection. Mark said that they just hired some teachers who both have some ties to the school as they were previous student teachers. He felt like they would stay in the community. When thinking about hiring candidates, it will be important to look at the rural experience each candidate brings with 
them. The more experience they have had, the more likely they are to be successful longterm.

The candidates' rural experience provides a unique connection to the demands of a rural school teacher. Teachers in rural public schools often wear many hats, as participants shared. Many of the roles they take on involve being active in the community. Because of this, administrators need to see if candidates will connect well with their school-community. Joel looks for people who are approachable, sensible, and will connect well with their community. He said candidates have to be grounded because that is how their community operates. Administrators should prioritize the applicant's values. They need to find out if the teacher's character mesh well with the community. Ethan agreed that it is important to figure out "how they will fit into what we're trying to do." He also mentioned that he tries to get a feel for the applicant's future plans.

There are also a few characteristics that administrators can look for in candidates during the hiring process. The first characteristic to seek is personability. It's understandable for a candidate to be nervous during an interview, but there should be some sense of comfort in the conversation. Candidates should show excitement for the profession. They should be outgoing and have a positive attitude. Elena is a great example. She shared that she is outgoing. She jumps "in the middle of whatever needs done" at school. This kind of teamwork also creates an atmosphere that builds into longterm success. Julia said she likes to have fun. "[I'm] energetic, but also want people to pull their weight." She prefers to be a team player with her coworkers.

Candidates should also be goal driven. Almost all participants in this study said that successful long-term teachers are always looking to grow in the profession. Melissa 
said she is "very goal oriented. I am very driven by goals, but also the progress in meeting the goal." This encompasses the areas of structure and organization. These are two characteristics for administrators to look for during the hiring process. Emma joked that she is a "casual perfectionist." She wasn't the only one. Nicole "doesn't like things to get stale." She said that she is constantly reaching out for new ideas to incorporate into her classroom. Mya also said that she likes to be innovative. James agreed that he is flexible and willing to try new things. Natalie agreed that her teachers are always looking for opportunities to improve. Successful long-term candidates will have a willingness to want to learn new things.

Maintaining a positive reputation. One aspect that was mentioned by many participants was the idea of a positive reputation that first encouraged them to apply to the district they are currently working in. Administrators agreed that their school's reputation is something that brings in new teachers. Mark shared that one reason why other schools respect his is because "we do things right." Mya agreed that "Marshall City had a really good reputation." She mentioned seeing them win awards for academics, as well as athletics before applying.

Current staff play a large role in the recruitment piece by helping the district maintain a positive reputation. Natalie, the principal at New Falls, share that they rely on "word of mouth" to bring new teachers to their district. Joel said something similar. His teachers are advocates for Joanstown. Having his teachers talk to others in the profession about all the fantastic things they have going on "really helps us out." Many teacher participants shared that they heard great things about the school and administration from staff that already worked in the district. Mya said teachers, community members, and 
parents always shared the same message. She knew that "if I ever had the privilege of working there, with such a high reputation, I would take the opportunity."

In order to maintain a positive reputation, administrators must be strategic in their planning. The district should look for opportunities to partner their staff with outside organizations, as well as connect to the local media for all the progressive work being done inside the building. Another aspect to consider would be the use of social media accounts by staff for the intended purpose of sharing school information. In doing these things, a positive message could be spread about their district much farther than they realize.

\section{Retention}

Induction programs. In order to retain teachers in rural public schools, districts have to satisfy their teachers. This study found that teachers look for support throughout each school year not only from their administrators, but also their coworkers and the community. That means school districts have to be more intentional in connecting teachers new those supports. A recommendation that encompasses all of those aspects is an induction program.

In order for induction programs to be successful, someone within the district must take on the lead role to organize the agenda. Melissa said that her principal was in charge of the teacher induction program at Marshall City. Her principal "went through everything with us." Another option is to have a group of teacher leaders organize the program. Natalie's school has a professional development committee that she works with to support new teachers. When organizing an induction program, it is important to think about each aspect of what can support a new teacher. 
To begin, it's important to show new teachers the entire school-community. Joel thinks that their induction program is "really important. It shows the new teachers the Joanstown community. It takes them around to some small businesses and lets them get to know the parents." He said that giving his new teachers a visual of the community they are serving helps prepare them for the start of school. Many districts believe that bridging the gap between the school and community is part of their duty to new teachers.

Next, the induction program should connect new teachers to a mentor teacher who is a veteran in the building. Participants shared that many interactions were first encouraged by the teacher induction programs set up at each school. Mya said that she thinks that mentoring is a necessary component for new teachers to be successful. "Training, orientation, and mentorship, they are just so crucial to the induction process. [It helps] you get to know everything." Pairing new teachers up with veterans can help them adapt to their surroundings. Many participants shared that they had more than one traditional mentor. Often times, their administrators paired them up with someone on their grade level team, as well as someone who worked within their curriculum department. Mark said they do this because then "we have at least a couple of individuals that are meeting with them regularly to try to give them support." Participants mentioned that there were scheduled meetings for mentors and new teachers, but most met fairly regularly to have day-to-day discussions.

Lastly, building time in to connect with teachers is important, but districts should build time in with administrators also. Nora attended back to school professional development the day before the rest of the staff came back for part of her induction process. Something that has always stuck with her is that she met the superintendent on 
her first day. He came in to speak to the new teachers and that had an impact on her. Natalie said that they also take new teachers out to lunch to try to "build rapport with them."

Administrative support time. Administrator support must go far beyond the induction program. Cooper feels like all teachers need a supportive administrator in order to be successful. Ethan shared that his support is non-stop. "Those first-year teachers, I just really try to get in their ear." He tells them how great they are doing and asks what he can do to help. Administrators must build in intentional time with new teachers. There were many ways mentioned by participants.

Administrator support should be tailored to meet the needs of each district and individual. For example, Natalie does what she can to eliminate extra stressors in the lives of her new teachers. Sometimes that means covering class for them, while other times it means purchasing programs to help teachers to their jobs more effectively. In Easton, Ethan wants his teachers "to feel super comfortable with me." Having an opendoor policy allows his staff to have that sense of comfort. Mark also likes to keep his door open for questions or time to talk. It is important to him. He thinks "it builds relationship and comfort" with new teachers. Joel mentioned how observations are used in terms of support at Joanstown. Observations can be used to tell new teachers what they are doing well. "I think that gives our new teachers a great deal of support."

Mark also likes to ask his staff what he can do better to support them. He believes that it provides ownership in their work. Elena agreed. She often hears how much her principal appreciates the work the teachers in the building are doing. "What can I do to support you?" is often a phrase he asks the staff. That creates a positive atmosphere in the 
workplace. Jacob said that his principal creates a similar environment. He "has an energy about him that's really good." He creates a "very pleasant work environment." As an administrator, it will always be beneficial to be an active listener. Caleb says his superintendent is “completely empathic and understanding. He likes to listen. He doesn't like to tell people what to do. He likes to hear people's input. And that's huge for me." Clear communication is key in any organization. Caleb shared how "nothing frustrates the community and staff as a whole" like lack of communication.

Many teachers feel like they know their principal on a deeper level because of outside connections. Emma said her principal "treats us like professionals, while at the same time, caring about our lives." Nina shared how much she got to know her principal through their own children being friends. Another way that several teachers were connected to their administrators was through organizations such as $4 \mathrm{H}$, which provides real life experience to students interested in health, science, agriculture, and civics. Being involved with organizations like $4 \mathrm{H}$, as well as committees, athletics, and other activities allows teachers to get to know administrators outside of their normal role at school. This helps new teachers, especially, feel connected.

Collaborative opportunities. When asked why his teachers stayed an average of 14 years, Mark said that it's because they are supported. "They are supported if they want to try something new or if they want to improve." Being a supportive administrator comes in many forms. One of those may be in prioritizing collaborative opportunities for staff to grow professionally. This may be something that happens on a schedule each month or something that is focused on new teachers. Either way, administrators must be intentional with this. 
There are a variety of ways that this can be provided. For example, in Coalsville, Cooper believes teachers "need to be provided the resources" because if not, they aren't able to do their jobs effectively. Not only do teachers need time to discuss these matters with each other, they also need training for some of the materials they choose to use. Nicole does not like when something new is presented to the staff without the resources to support it. Many participants mentioned having professionals come to their school to train them. Administrators can also use teacher leaders in their building to provide meaningful professional development. These opportunities can be organized by a need's assessment. That can make teachers feel like their voices are heard. These trainings are usually scheduled during a monthly faculty meeting or on an early release day.

Another way to provide professional collaboration is through the connections made with other schools. For example, New Falls sends teachers to other schools to collaborate with teachers who are using the same curriculum. This allows the teachers at New Falls to be better prepared and bring back tried and tested ideas. Spending the first few calendar days with other schools in the area can also be beneficial for collaboration. Joel shared that his school spends time with other schools in the conference. Sending teachers to conferences is also another great option. Getting out of the building allows teachers to gain valuable "insight and it's new scenery for them," according to Natalie.

Having a common time for teachers to meet is also ideal. This can be understandably difficult in rural schools. Several participants mentioned having a plan time with a small team of other teachers. Teachers can spend time looking at discipline and academic data, as well as plan integrated lessons for the upcoming week together. 
Matt feels like this allows his time to be in constant communication. Nina also appreciates that she has a common plan time to meet with other teachers.

\section{Summary}

Teachers are leaving their schools at an unprecedented rate. As stated earlier, many factors are connected to recruiting and retaining teachers who will be suitable for long-term employment. Finding the right person for a vacant teaching position can have a multitude of benefits for students, including increased achievement. This makes the hiring process essential to the recruitment of the right person (Podolsky et al., 2016). Keeping in mind that each individual requires a different environment (Holland, 1997), the environment must be maintained to keep the individual satisfied (Dawis \& Lofquist, 1984). Doing so will cause less stress (Edwards \& Cooper, 1990) and increase the probability of retention.

"Although teachers may be more motivated by a desire to 'do good' than some other workers, altruism alone is not enough to attract high-ability candidates to the profession and keep them in the classroom" (Podolsky et al., 2016, p. 9). This process of retaining quality teachers begins with recognizing that people want to work for an organization that will respond to their needs for useful work (Bolman \& Deal, 2013). School leaders need to develop a thoughtful hiring process, communicate the organization's values, and respond to their employees' needs. Investing in these practices should lower s teacher's intention to leave (Vekeman et al., 2018). By finding the best teacher fit for their school district, administrators can create long term success (Bolman \& Deal, 2013). 
SECTION TWO

PRACTITIONER SETTING FOR THE STUDY 


\section{History of the Organization}

\section{The Structure of Missouri Public Schools}

The State Board of Education is the governing authority for public education in Missouri. The Governor appoints eight citizens to the board, which are then confirmed by the Senate (Missouri Department of Elementary and Secondary Education, 2019a). The Board supports students in public education from preschool through secondary school completion. The Board sets policies for the Department of Elementary and Secondary Education (DESE). They also are in charge of operating several other youth based educational facilities such as the Missouri School for the Blind in St. Louis, the Missouri School for the Deaf in Fulton, and the Missouri Schools for the Severely Disabled, which is a statewide program (Missouri Department of Elementary and Secondary Education, 2019a). They also address disabled adult needs through Vocational Rehabilitation and their Sheltered Workshop program (Missouri Department of Elementary and Secondary Education, 2019a).

DESE "is the administrative arm of the State Board of Education” (Missouri Department of Elementary and Secondary Education, 2019b). This agency works with educators and government agencies to regulate public schools in the state of Missouri with the goal that all students in Missouri will graduate ready for success. DESE has three strategic priorities that help the state focus on accomplishing their goal: public schools must provide access, opportunity, and equity to all students; teachers and leaders are prepared to help students achieve in their classrooms; and ensure those teachers are

effective in their classrooms through continuous improvements (Missouri Department of Elementary and Secondary Education, 2019b). 
The Missouri School Improvement Program (MSIP) is considered an accountability system by DESE. The MSIP began in 1990 and has been updated multiple times since (Missouri Department of Elementary and Secondary Education, 2019c). The five standards assessed by the MSIP are academic achievement, subgroup achievement, college and career readiness, attendance rate, and graduation rate (Missouri Department of Elementary and Secondary Education, 2019d). A comprehensive score is calculated out of 100 and is "used to determine the accreditation level of a school district" (Missouri Department of Elementary and Secondary Education, 2019d, p. 9).

The Missouri Assessment Program (MAP) is used to provide data for the areas of achievement on the MSIP. The MAP assesses students in English language arts, mathematics, and science in third through eighth grades. The MAP test is multiple choice and machine scored with a small amount of constructed response items. It is designed to check for understanding of the Show-Me Standards, 40 knowledge and 33 performance standards that meet the required state law, the Outstanding Schools Act, which was passed in 1993 (Missouri Department of Elementary and Secondary Education, 2019e).

There are 115 counties in Missouri; 33 of those counties are classified as being entirely rural (Missouri Census Data Center, 2019). According to the Census Bureau, rural is defined as "all territory, population, and housing units located outside of urbanized areas and urban clusters" (Missouri Census Data Center, 2019, para. 5). Missouri has $97.4 \%$ of its land classified as rural while only approximately $21 \%$ of Missouri's population lives in a rural area (Missouri Census Data Center, 2019).

As of July 2019, Missouri had 518 public school districts. Of those districts, 448 have a high school, while the other 70 schools serve kindergarten up to possibly eighth 
grade (Missouri Department of Elementary and Secondary Education, 2019f). According to Cao (2019), there are only 13 counties in Missouri that contain urban areas (Cao, 2019). When looking at where school districts fall within counties (see Appendix A), approximately 409 school districts are located in rural areas.

Depending on each school district's size, they may have a slightly different hierarchical structure. Public school districts are run by a Board of Education. Boards of Education are comprised of elected members who "make district policy by voting at weekly or monthly meetings, where they review budget, educational, facilities and personnel matters" (Heibutzki, 2019, para. 2). They, along with the superintendent, lead initiatives that directly impact curriculum changes, facility updates, and strategies to meet district goals, according to Heibutzki (2019). The superintendent works closely with administrators to support teachers and ensure "that teachers meet state educational standards and school improvement plan objectives" (Heibutzki, 2019, para. 4). In smaller schools, the superintendent and principal positions may be held by one school official.

\section{Organizational Analysis}

Education is currently in a movement that forces data to be at the center of school improvement (Shen \& Cooley, 2008). Leaders can "avoid many perils of data use by embedding the data within [their] culture" (Datnow \& Park, 2014, p. 117). For years, educators have been mandated by the United States Department of Education to use data to inform their practice (Mandinach, 2012). There has been much debate between policymakers and educators on how data can be effectively utilized (Mandinach, 2012). Some staff simply comply with using data as it is mandated by district leaders (Datnow \& Park, 2014) where others need data "to meet the challenges of student success and 
sustainability head-on" (Gagliardi, 2018a, p. 189) by addressing areas of need to drive decisions (Shen \& Cooley, 2008). When leaders use data properly, organizations can invest in their priorities to become academically competitive (Gagliardi, 2018a).

\section{People as Assets}

Bolman and Deal (2013) have two assumptions that directly connect people with the organization in which they work. The first assumption is that organizations exploit people. District leaders could make decisions independent of others' input. This leader could be in control of the finances for professional development but might offer little to no professional development to staff members. What this district leader would not realize is that workers who are undertrained harm organizations through low quality production and costly mistakes (Bolman \& Deal, 2013). Employees who are not invested in their organization will look for ways to escape to a better job opportunity (Argyris, 1995; Bolman \& Deal, 2013). Schein (1993/2005) noted that when the leader of an organization does not address their own previously held beliefs to see if they fit the operating needs of their organizational system, it could be harmful to the organization. If the operating needs do not fit the need of the system, this can create a path of greater resistance among employees, creating a system that is not stable and will make employee permanence impossible (Johnson, 2018).

The second assumption is that "organizations exist to serve human needs" (Bolman \& Deal, 2013, p.117). An organization that invests in its employees can have a "positive impact on performance and profitability" (Bolman \& Deal, 2013, p.145).

Organizations need people's ideas, energy, and talent to be successful. An employee who has been invested in will bring a competitive advantage to their organization (Bolman \& 
Deal, 2013). These employees should also be rewarded for their efforts, and in doing so, the organization will meet the needs of their people. Successful organizations use this approach to become "the industry's most profitable firm" (Bolman \& Deal, 2013, p. 143).

\section{Culture is Essential}

The spirit of an organization produces the culture people feel when they enter the environment (Bolman \& Deal, 2013). Every organization has a culture which impacts symbolic traditions and ultimately affects daily work. Bolman and Deal (2013) also have assumptions related to culture. One of these assumptions is that the culture links an organization to a common goal which then create connections among workers. These connections can be formed in a variety of ways, such as through perspectives that build powerful symbolic messages (Tierney, 2012). In organizations, veteran staff pass along time-tested values and traditions through stories that guide everyday behavior. Failing to pass those messages on, according to Bolman and Deal (2013), could cause chaos and disarray. Due to high turnover rates at rural public schools, new stories end up replacing those of past heroics and tales of greatness that symbolized the true values of the district. A high rate of turnover prohibits positive effects of this ritual from transpiring which places undue hardship on the shrinking number of returning staff. Furthermore, this reduces the effectiveness of the induction process and can lead the organization's culture into turmoil. Unfortunately, negative culture is easily cultivated through a lack of rituals, stories, and leadership (Bolman \& Deal, 2013).

Leaders play a sizeable role in developing the culture of a group of individuals (Levi, 2017; Schein, 1993/2005). Once culture has been established, it is hard for an organization to change it (Bolman \& Deal, 2013). New leadership in rural public schools 
are often put at a disadvantage. Leaders are using data to assess the needs of the school while concurrently building relationships, whereas established leaders are "able to lay the groundwork for reform over a period of years" (Datnow \& Park, 2014, p. 39).

\section{Successful Organizations}

Leaders have a vital role in sustaining a positive culture. They also play an important role in the success of an organization (Cardoza \& Gold, 2018). Leaders must provide direction "guided by the same underlying principles" as the organization (Gill, 2010, p. 80). Bolman and Deal (2013) shared that leaders must make employees a focus of their work. Leaders who communicate a strong belief in their staff, are visible and empower others, and communicate the vision are less likely to lose people. Successful organizations "turn over [their] inventory faster than [their] people" (Bolman \& Deal, 2013, p. 142).

Bolman and Deal (2013) noted that effective organizations can identify the type of people who will work best within their organization. A suitable fit benefits both people and the organization, as people find significance in their work and the organization becomes successful because of it. Supporting staff rather than exploiting them puts managing people at the organization's center. While this type of philosophy provides direction, the people make it operational (Bolman \& Deal, 2013; Northouse, 2016). A culture of commitment will promote participation, open communication, and stability (Bolman \& Deal, 2013).

Levi (2017) suggested that organizations are often set up for staff to work as individuals rather than collectively; however, culture should embrace inclusion, cooperation, and harmony. This type of collective approach makes an organization 
stronger by enhancing team effectiveness in working towards a common goal, thereby uniting members within the same organization (Levi, 2017). According to Johnson (2018), working collectively integrates multiple, diverse perspectives during collaboration which can increase an organization's effectiveness. Having a variety of perspectives will bring creativity and innovation to the forefront when working with a team (Bolman \& Deal, 2013). According to Lencioni (2002), teams generate more trust within their organization, guiding those teams to work toward a common goal, thus increasing retention (Bolman \& Deal, 2103).

\section{Leadership Analysis}

Leadership is a process. Northouse (2016) emphasized that while leadership is focused on developing common purpose within people, management coordinates the activities accomplish the goal. Leadership and management overlap in several ways:

process, influence, people, and goals. Northouse (2016) stated that strong leadership also needs management so that changes can be meaningful. According to Kotter (1990/2011), these "are two distinctive and complementary systems of actions" (p. 37). Operations such as planning trainings for new employees provide what Northouse (2016) said is necessary "order and consistency to organizations" (p.13). Investing in people is the action of a leader who is sensitive to the needs and motivations of others and is important at any level of management.

Effective organizations need both management and leadership (Northouse, 2016), and school leadership is no different. Bush and Glover (2003) stated that school leadership can be understood as a process of influence based on clear values and beliefs and leading to a 'vision' for the school. The vision is articulated by leaders 
who seek to gain the commitment of staff and stakeholders to the dream of a better future for the school, its students and stakeholders. (p. 31)

Daniels, Hondeghem, and Dochy (2019) found that school leadership is often in the spotlight due to the increasing number of responsibilities administrators have, emphasizing the role administrators play in managing their schools, as well as increasing effectiveness. Administrators can enhance student success "through their influence on teachers" and policy (Daniels et al., 2019, p. 110).

\section{Implications for Research in the Practitioner Setting}

Podolsky et al. (2016) found that five factors influenced teacher's decisions to enter and stay in the profession: salaries, preparation, hiring practices, induction support, and working conditions. The current study will have implications for hiring practices for leaders in rural school settings. The hiring process has a large impact on teacher retention, but can also be the most problematic.

When applicants participate in an information-poor hiring process, their fit is usually lower than expected, according to Ellis, Skidmore, and Combs (2017). Having a systematic process is the best way to find the most qualified for each position, but that takes time, money, and training, and many schools "have not invested the resources necessary to improve this aspect of teacher hiring" (Ellis et al., 2107, p. 452). Principals who want to raise student achievement must remove these barriers in the recruiting process. They need to hire early and allow applicants to "have the opportunity to evaluate the organization" (Ellis et al., 2107, p. 453). Applicants should also be assessed for how well they match "the culture and values of the school...especially in high-need schools" (Ellis et al., 2107, p. 454). 
When looking at the two types of fit most connected with the current study, person-job and person-organization, the hiring process is no different. Kristof-Brown et al. (2005) stated that "applicants generally get recruited based on elements of the job and organization simultaneously" (p. 294). With that being said, person-job fit is more closely related to the current study due to most hiring techniques emphasizing the skills needed to be successful at a specific job (Bowen, Ledford, \& Nathan, 1991). This study will help determine if this is also the case within a rural school setting.

\section{Summary}

Organizational leaders should share their values with employees as soon as they start recruiting them. They also need to continue sharing them through long-term employment, paying close attention to how they communicate. Not only will this help leaders retain employees, it will also help attract and hire them. Organizational leaders who openly communicate their values will attract people who share those same values; people will be "inspired by an organization that reinforces" the same values they have (Kristof-Brown et al., 2005, p. 326). 


\section{SECTION THREE}

SCHOLARLY REVIEW FOR THE STUDY 


\section{Review of the Extant Scholarship}

A perfect fit may not exist, according to van Vianen (2018), but some types of fit are more important than others. Person-job fit and person-organization fit are the two types most connected to the theory for this study. Schneider's (1987) attraction-selectionattrition framework supports this as it is defined as a model for how organizations could attract, select, and retain those people who share the same goals. People are selected for an organization and remain in it if they fit (Schneider, 1987). This means that if they leave, they likely did not fit within the organization. In other words, this framework assumes that fit will lead to retention (Schneider, 1987; Schneider, Goldstein, \& Smith, 1995). Kristof-Brown, Zimmersonman, and Johnson (2005) found that although the [attraction-selection-attrition] model suggests that attraction and selection will help screen out people who do not have a good person-organization fit, organizations are required to hire based on job-relevant qualifications. This implies that the person-job fit of employees at any given time should be high, but that some people with low or modest person-organization fit will likely be hired. If employees have poor person-job fit, they may try to develop their skills, change jobs internally, or even be demoted. However, if they have a poor personorganization fit, the attraction-selection-attrition model implies that they will eventually leave the company, making person-organization fit a better predictor of eventual turnover. (p. 317)

When retaining human talent is viewed as a crucial competitive advantage (Reichheld, 1996), organizations could find person-organization fit most useful when attempting to reduce turnover (Kristof-Brown et al., 2005). 
The attraction-selection-attrition model has been studied outside (Hoffman \& Woehr, 2006; Wheeler, Gallagher, Brouer, \& Sablynski 2007) and inside the educational context (Pogodzinski, Youngs, \& Frank, 2013; Skaalvik \& Skaalvik, 2011). In an educational setting, this model lays out the process in which teachers find schools attractive based on their perceptions of congruence between their own personality and the values of the school (Van Beurden, Van Veldhoven, Nijendijk, \& Van De Voorde, 2017). School values in this sense are a wider collection of general human values in the workplace (de Vos, Buyens, \& Schalk, 2005). Values are at the core of fit, according to Chatman (1989). If an individual's personality is similar with the values currently in the environment, the more likely the person and the organization will fit (van Vianen, 2018).

Person-job fit is related to satisfaction and occupational commitment (van Vianen, 2018) and may have some specific attributes worth looking at when trying to hire the right applicant. Districts will want to take an intraindividual approach when looking at potential hires to find which will best meet the interests, needs, and values of their environment (van Vianen, 2018). Caplan (1987) suggested that each work environment has a taxonomy of characteristics that make up the organization and its tasks, and a poor fit has a low employee retention rate.

Just as in person-organization fit, person-job fit outcomes are optimal when "individuals experience fit on high personal attributes" (van Vianen, 2018, p. 91). Van Vianen (2018) found that "personality traits...impact employee job satisfaction, subjective well-being, and performance" (p. 84). Since there may be some specific attributes worth looking at when trying to hire the right applicant, district personnel should take an individualized approach when looking at potential hires to find who will 
best meet the interests, needs, and values of their environment. Ultimately there is a positive relationship between fit and teacher satisfaction (Ellis, Skidmore, \& Combs, 2107) which potentially leads to increased rates of retention.

\section{Satisfaction}

Teachers cited dissatisfaction as an important reason for leaving their teaching positions (Carver-Thomas \& Darling-Hammond, 2017). Ellis et al. (2017) found that teacher satisfaction has been declining, noting that in 2012 , only $39 \%$ of teachers indicated they were satisfied, which is a drop from 2008 when $62 \%$ said they were satisfied. This recent decline in teacher satisfaction led researchers to focus on new variables that impact teacher satisfaction. Ellis et al. (2017) found that having a preview of the job and fit have a statistically significant impact on satisfaction.

Many positive outcomes are experienced in the form of what $\mathrm{Yu}$ (2009) called work-based affect. "This broadly encompasses the moods, emotions, and affective attitudes that are experienced at work or are evoked by work-based targets, such as one's job (e.g., satisfaction) or organization (e.g., commitment)" (Yu, 2009, p. 1210). Job satisfaction, organizational commitment, and turnover intent are often connected to fit (Allen \& Meyer, 1990, 1996; Brief \& Weiss, 2002; Locke, 1984; Yu, 2009). Satisfaction and commitment, in particular, are often characterized by feelings of pleasantness, while dissatisfaction is associated with individuals feeling sad (Watson \& Tellegen, 1985; Yu, 2009). Research focused on organizational human resource policies has found there are policies in the areas of recruitment that can predict fit among new employees (Cable \& Parsons, 2001; Chatman, 1989, 1991; Yu, 2009). 
Experts agree that maintaining a positive hedonic balance is a goal for all employees (Yu, 2009; Buss, 2000; Larsen, 2000). “Theories of cybernetics, coping, and job satisfaction provide elucidating accounts of how people can manage P-E fit in order to achieve hedonistic goals" (Yu, 2009, p. 1214). Coping and job satisfaction are the outcomes that stand out the most, according to Yu (2009). He continued by sharing that coping may cause individuals to "seek change to their objective physical and social environment (e.g., by quitting a job)" (p. 1214), while job satisfaction theory evokes behavioral responses that also include quitting.

Organizations with enhanced human resource policies can support employees in managing their P-E fit (Yu, 2009). Principals with high human resource skill take developmental needs of new teachers into account when they provide individualized support through professional development during the early stages of their careers (Vekeman, Devos, Valcke, \& Rosseel, 2018). These types of principals "give new teachers individual support, stimulate professional development, make enough time for (in)formal talks, listen to new teachers' needs, or give them time to work on weaknesses" which all increase teachers' P-O fit according to Vekeman et al. (2018, p. 833). They continued to say that "management styles which support autonomy needs, reward structures or performance systems that provide feedback about one's competency, or activities that satisfy relatedness needs" are likely to increase satisfaction (p. 826).

Ultimately, when employees internalize organizational values, a culture is created that determines their emotional satisfaction. This can better connect the employees and the organization in which they work (Vekeman et al., 2018). "Higher P-O fit levels (in schools with both highly strategic and HR oriented principals) will have a more positive 
impact on job satisfaction, which in turn will decrease the teacher's intention to move," according to Vekeman et al., (2018, p. 827). They continued to share that the better the connection of person-organization fit, the more satisfied teachers will be at their job. The idea of job satisfaction resulting in retention has been supported in various educational literature (Perrachione, Rosser, \& Petersen, 2008) as well as hypothesized by others (Chatman, 1991).

\section{Abilities}

Finding a suitable fit can increase student achievement (Bohndick, Rosman, Kohlmeyer, \& Buhl, 2018; Etzel \& Nagy, 2016; Li, Yao, X., Chen, K., \& Wang, 2013) along with teacher satisfaction (Heise, Westermann, Spies, \& Stephan, 1997). The individual's abilities need to match the demands of the organization in order to have a positive effect on academic outcomes (Bohndick et al., 2018; Edwards et al., 1998; Edwards \& Shipp, 2007; Reis \& McCoach, 2000). If the employee's abilities exceed the demands there could be negative effects in motivation; this means that the organization may need to tailor the environment to match the individual's abilities (Bohndick et al., 2018; Edwards, Caplan, \& van Harrison, 1998; Edwards \& Shipp, 2007). One thing that can be used to personalize one's experience is professional development (Johnson, Birkeland, Kardos, Kauffman, Liu, \& Peske, 2001; TALIS, 2008), which can act as a precursor to teacher attraction and retention (Johnson et al., 2001), classroom performance (Desimone, Porter, Garet, Yoon, \& Birman, 2002), and job satisfaction (Shen, Leslie, Spybrook, \& Ma, 2012).

According to Bohndick et al. (2018), "Demand-abilities fit are relatively rare" (p. 841), but can predict academic achievement (Etzel \& Nagy 2016; Li et al. 2013) and 
teacher satisfaction (Heise et al. 1997). Inadequate abilities often produce lower performance on tasks (Bohndick et al., 2018; Edwards \& Shipp, 2007; Muchinsky \& Monahan, 1987; Waldman \& Spangler, 1989). "Intuitively, it therefore seems plausible that for positive effects on academic outcomes, individual abilities have to simply exceed situational demands...In fact, performance seems to increase when abilities increase toward demands" (Bohndick et al., 2018, p. 842). Unfortunately, there is a possibility that abilities may exceed demands which can result in boredom (Bohndick et al., 2018; Edwards et al. 1998; Edwards \& Shipp 2007; Reis \& McCoach 2000).

It is suggested "that an optimal correspondence between abilities and demands might be more beneficial than abilities simply exceeding demands" (Bohndick et al., 2018, p. 842). According to Bohndick et al. (2018)

Higher education researchers, lecturers, and policymakers should focus even more on subjective demands-abilities fit...it is not sufficient when individual abilities simply exceed situational demands. Instead, they should match them. This is in line with findings on P-E fit theory from the organizational context, where reasons for such effects are found in motivational changes occurring when abilities exceed demands (e.g., negative effects of boredom...). (p. 847) Looking at fit at an individual level, Kristof-Brown et al. (2005) wondered what prompted change in fit over time. In order to know more, researchers would need to assess both perceived and actual levels of fit levels at entry and then longitudinally until departure (Kristof-Brown et al., 2005). Kristof-Brown et al. (2005) warned that fit is "a multifaceted approach that involves demands and supplies of jobs, coworker characteristics, and organizational elements" (p. 325) and that Chao, O'Leary-Kelly, 
Wolf, Klein, and Gardner (1994) offer managers "specific techniques aimed at increasing the levels of actual and perceived fit" (p. 325). Solutions include "tailoring the employee's abilities to the demands of the organization" (Caplan, 1987, p. 258) or "altering the organization's resources to meet the needs of the employee" (Caplan, 1987, p. 258). Ultimately, there is a suggestion to address change at a systemic level (Katz \& Kahn, 1978).

Related to the degree of $\mathrm{P}-\mathrm{O}$ fit is the feature of strategic human resource management. "People report a better fit when human resource practices are in place, which ensure that employees have the required skills and abilities for performing their tasks (e.g. by a critical selection of new employees), employee motivation is encouraged (e.g. by a fair appraisal of employees' performances), and that employees get the opportunity to participate (e.g. by having the opportunity to work in a team)" (Vekeman et al., 2018, p. 821). In layman's terms, there is a positive relationship between strategic human resource management and job satisfaction.

\section{Plateaus}

Person-job fit and person-organization fit decrease boredom in the workplace (Edwards \& Van Harrison, 1993), which is a characteristic connected to job content plateau (Allen, Russell, Poteet, \& Dobbins 1999). The job content plateau "can influence an employee's fit into their work role and environments" (Jiang, 2016, p. 3), and data show that reaching a plateau can have negative consequences for employees (Chang, 2003; McCleese \& Eby, 2006). Some of those could be decreased satisfaction in their place of work and organizational commitment. According to Jiang (2016), the job content plateau may be the most dangerous for retention purposes because it impacts employees' 
attitudes from feeling no longer challenged by work or job responsibilities. New efforts thus have been put into exploring various antecedents of the job content plateau (Jiang, 2016) as researchers are hoping to identify strategies for solving issues caused by the job content plateau. Some antecedents have been identified, such as tenure, personality, and supervisory support (Armstrong-Stassen, 2008; Hofstetter \& Cohen, 2014; Jiang, 2016).

Jiang (2016) suggested, employees who have reached a job content plateau need to have career adaptability to help them continue to be successful in their place of work. Career adaptability is a psychosocial construct that involves self-regulation skills (Savickas, 1997; Savickas \& Porfeli, 2012) and is comprised of "attitudes, competencies, and behaviors" (Savickas, 2013, p. 45) that individuals must use in order to fit in a work environment that suits them (Jiang, 2016). Ultimately, career adaptability allows employees the ability to better fit into their jobs and organizations (Jiang, 2016) which, based on person-environment fit theory, should reduce job content plateaus (Edwards, Caplan, \& van Harrison, 1998; Jiang, 2016).

\section{Dimensions}

Jiang (2016) shared that there are four dimensions through which an individual can adapt to their place of work: concern, control, curiosity, and confidence. These dimensions "function to guide employees' thoughts, reflections, and perceptions at work" (Jiang, 2016, p. 3) and help employees perceive their person-environment fit (Guan, Deng, Sun, Wang, Cai, Ye, Gu, Wang, Zhang, \& Li, 2013). According to Jiang (2016), career concern directs employees to spend time and energy in planning how to fit into the characteristics of work settings; career control assists them with work matters based on careful decisions and conscientious behaviors; career curiosity 
facilitates them in exploring the self and the environment; and career confidence ensures that employees will sustain their efforts and persistence should difficulties emerge when they blend into their jobs and organizations. (p. 3)

These dimensions are psychological resources rooted in career adaptability (Jiang, 2016) and understanding the role these dimensions play in the person-environment fit process can increase the chances of organizations finding a suitable fit between personal attributes of an individual and the characteristics of the job (Jiang, 2016; Guan et al., 2013).

The two types of fits that had the highest significance in relation to the four dimensions are person-job and person-organization (Jiang, 2016). If researchers look at the dimensions and how they are connected to values, personality, and needs of an individual, they are more likely to discover a more holistic evaluation of fit (Bretz \& Judge, 1994).

\section{Misfit}

There are additional areas of person-environment fit that are distinctly related but classified under misfit topics. Misfit is something that appears in most workplaces, according to Wheeler et al. (2007) and "is generally conceived as the negative end of the fit continuum, and is associated with discomfort or incompatibility" (Follmer, Talbot, Kristof-Brown, Astrove, \& Billsberry, 2018, p. 441). Some of the topics classified under misfit include underemployment, overqualification, role overload, and relative deprivation (Kristof-Brown et al., 2005). Individuals can provide descriptions of these topics to provide a better understanding of misfit experiences (Billsberry, Ambrosini, Moss-Jones, \& Marsh, 2005; Follmer et al., 2018; Kristof-Brown \& Guay, 
2011; Shipp \& Jansen, 2011). The data presented by Follmer et al. (2018) show how "motivating the pain of misfit can be, and the kinds of reactions it motivates" (p. 458). Follmer et al. (2018) stated that virtually all participants shared emotionally laden, pain-filled stories involving misfit with jobs, coworkers, supervisors, and organizational cultures. They were quite capable of describing parts of the environment with which they fit and those with which they did not. (p. 459)

This reinforced the idea that "individuals are simultaneously embedded in multiple aspects of the environment" (Jansen \& Kristof-Brown, 2006, p. 197).

Follmer et al. (2018) found that employees will often remain in poor fit workplaces as the decision to leave is complex. Often times there is a lack of other opportunities for employees who are in a misfit situation which causes them to stay (Wheeler et al., 2007). By viewing employees as arbiters of fit, we can help people manage their fit and reduce negative consequences of misfit (Follmer et al., 2018). While fit is desired, it is assumed that misfit is an unpleasant experience (Edwards \& Shipp, 2007; Follmer et al., 2018) and, depending on the severity of the misfit, there could be "negative psychological, physiological, and behavioral outcomes" (Edwards \& Cooper, 1990, p. 294).

Many times, a change at work can create a misfit. "Fit assessment may reoccur at any time when the environment or person changes or when new social signals are introduced" (Follmer et al., 2018, p. 457). Follmer et al. (2018) suggested that this presents the idea of a continuous cycle of fit reassessments when misfit presents itself. 
There are five prototypical paths individuals are characterized by. They are the "fast leavers, adjusters, eventual leavers, chronic pretenders, and malcontents" (p. 457).

There is an "array of strategies people use to respond to misfit" at their place of work (Follmer et al., 2018, p. 441). Follmer et al. (2018) “identified three general responses to misfit: resolution and relief-seeking approaches represent the more positive end of a response continuum, and resignation represents the more negative end" ( $p$. 450). While employees are motivated to resolve misfit (Yu, 2013), "existing research has primarily emphasized poor attitudes and turnover as typical reactions" (Follmer et al., 2018, p. 441). Follmer et al. (2018) found that individuals who took the resignation approach

began to accept misfit as a reality of their condition that could not be fixed or alleviated; it could only be endured. They were unable to buffer misfit with fit because it was so extreme that other types of fit could not compensate. They did not view misfit as temporary, and could not alleviate it by simply changing others' perceptions. They also believed that environmental change was impossible, and personal change was not desirable or feasible. (p. 455) Individuals can also "use conscious and unconscious efforts to manipulate their experiences of misfit into ones of fit" (Follmer et al., 2018, p. 442). Follmer et al. (2018) provides "suggestions for how to reduce the misfit-turnover association" (p. 441). Follmer et al. (2018) found that fit is not just a matter of finding where individuals belong, but rather a continuum of "complex sequence of adjusting cognitions and behaviors to maintain PE compatibility" (p.460). Individuals defer leaving until it is their last option (Follmer et al., 2018) and often try "a variety of other options to resolve or 
relieve misfit" first (Follmer et al., 2018, p. 460). This allows places of work to view misfit as an opportunity for growth. Some individuals who experience misfit may also rely on nonwork activities to lessen the pain of misfit (Vogel, Rodell, \& Lynch, 2016). According to Follmer et al. (2018), buffering, temporal framing, and reframing misfit as a source of pride are consistent with Harrison's (1978) definition of defense mechanisms because they primarily address the subjective perception of misfit. Leaving and adjustment strategies are coping mechanisms because they address misfit by changing its underlying causes...there is often crossover between the approaches. (p. 460) With all of this being said, Follmer et al. (2018) believed that changing surface-level behaviors "does nothing to resolve the underlying conditions of misfit" (pp. 460-461). Misfit provides managers an opportunity to engage with employees in order to develop and retain them (Follmer et al., 2018). Follmer et al. (2018) suggested "engaging employees by encouraging them to voice their concerns" (p. 462). This could provide resolution of feelings of misfit, according to Cable, Gino, and Staats (2013). "Fitting in does not appear to come easily to most people, but instead relies on active, effortful processes requiring cognitive and behavioral components and a large dose of persistence" (Follmer et al., 2018, pp. 462-463).

\section{Stress}

Stress is caused through misfit, according to Edwards and Cooper (1990). Cummings and Cooper (1979) push this information further by the use of a cybernetic framework to show how discrepancies between an individual's idealistic work environment and their actual work environment result in stress. Edwards and Cooper 
(1990) suggested that "the person and the environment [are] joint determinants of stressrelated outcomes (p. 293). Ultimately, it is a "lack of correspondence between characteristics of the person (e.g. abilities, values) and the environment (e.g. demands, supplies)," according to Edwards and Cooper (1990, p. 293). Often workplace demands are higher than the individual's ability to complete the tasks (Karasek, 1979). McGrath (1976) shared his model that indicates "stress involves a perceived environmental demand which threatens to exceed the person's capabilities and resources" (pp. 294-295). Others agree that stress occurs when demands are high and ability to complete routine practices are low (Karasek, 1979). Edwards and Cooper (1990) call this low decision latitude and ultimately stated that "stress-related transactions between the person and the environment involve both [demands-abilities and skills-values] misfit” (p. 295).

\section{Perceived Fit}

Kristof-Brown et al. (2005) warned that fit is "a multifaceted approach that involves demands and supplies of jobs, coworker characteristics, and organizational elements" (p. 325). Kristof-Brown et al. (2005) shared that fit research "rarely has been synthesized to draw conclusions about the true impact of fit on [an] individual-level" (Kristof-Brown et al., 2005, p. 282). There are concepts designed to increase actual and perceived fit, as this could impact those individual-level experiences (Chao et al., 1994). Perceived fit can be incorporated into a broader model of turnover (Mitchell, Holtom, Lee, Sablynski, \& Erez, 2001; Mitchell \& Lee, 2001) where person-organization fit is a measure of psychological agreements (Masterson \& Stamper, 2003). KristofBrown et al. (2005) described the agreements being measured by "the 'fulfillment of needs' between employees and organizations in social exchange relationships" (p. 322). 
An area of interest that could be studied further is "what prompts changes in individuals" levels of fit over time, from pre-entry to turnover" when "following entry, impact on both perceived and actual levels of fit" can be assessed (Kristof-Brown et al., 2005, p. 321).

\section{Model of Vocational Personality Types}

Holland's (1997) work focused around helping people find practical ideas to "select jobs, change jobs, and attain vocational satisfaction" (p. 1). The theory is centered on a variety of factors including behavior and personalities (Holland, 1997). Holland (1997) characterized people by six personalities: realistic, investigative, artistic, social, enterprising, and conventional. Each type has specific traits and behaviors associated with it and is "the product of a characteristic interaction among a variety of cultural and personal forces including peers, biological heredity, parents, social class, culture, and the physical environment” (Holland, 1997, p. 2). "The personality types epitomize some common ways in which people develop in our culture" (Holland, 1997, p. 4). Through these experiences, a person would develop interests and competencies that would lead them to have a specific disposition (Holland, 1997). This provides people with "a characteristic repertoire of attitudes and skills for coping with environmental problems and tasks" (Holland, 1997, p. 2). In addition to six personality types, there are also six types of environments (Holland, 1997). Personalities and environments are categorized by the same titles which means that there are 720 different "patterns or repertoires for coping with that person's environment" (Holland, 1997, p. 3).

We can determine a person's personality type through a variety of methods: "the person's scores on selected scales from interest and personality inventories, choice of vocation or field of training, work history or history of preemployment aspirations, or 
combinations of these data" (Holland, 1997, p. 3). Environments are designated by the type of people who congregate there. For example, if social types of people are the largest percentage of people in a particular environment, the environment would be labeled as a social type (Holland, 1997). "If we know a person's personality pattern (or profile) and the pattern of his or her environment, we can, in principle, use our knowledge of personality types and environmental models to forecast some of the outcomes of such a pairing" (Holland, 1997, p. 4).

By pairing the person and the environment, we can understand and predict outcomes. "These outcomes include vocational choice, vocational stability and achievement, educational choice and achievement, personal competence, social behavior, and susceptibility to influence" (Holland, 1997, p. 2). There are also secondary concepts that can be applied to a person or an environment. The concepts are consistency, differentiation, identity, congruency, and calculus. The concept most related to personenvironment fit theory falls within congruence. Holland (1997) stated Different types require different environments. For instance, realistic types flourish in realistic environments because such an environment provides the opportunities and rewards a realistic type need. Incongruence occurs when a personality types lives in an environment that provides opportunities and rewards foreign to that person's preferences and abilities - for instance, a realistic type in a social environment. (p. 5)

When Holland (1997) was developing the environmental models there were six principles that "seemed plausible, or at least hard to imagine as false" (p. 7). Two of the principles directly impact person-environment fit theory. The first is that "the members of 
a vocation have similar personalities and similar histories of personal development" (Holland, 1997, p. 10). The idea is that when people chooses a vocation, there is a reason either within their personality or history, so "it follows that each vocation attracts and retains people with similar personalities" (Holland, 1997, p. 10). The second principle is that "vocational satisfaction, stability, and achievement depend on the congruence between one's personality and the environment in which one works" (Holland, 1997, p. 11). People "are more likely to perform well at a vocation in which [they] 'fit' psychologically" (Holland, 1997, p. 11). According to Holland (1997), a fitting environment is one in which a person's preferred activities and special competencies are required and his or her personal disposition and its associated characteristics — a special outlook on the world, role preferences, values, and personal traits—are reinforced. (p. 11)

Holland (1997) stated that the model he used organized the information about people and jobs. Behaviors are based on the people and environment interacting with one another. This alludes to the theory not being "a one-way street; jobs change people, and people change jobs" (Holland, 1997, p. 12).

\section{Theory of Work Adjustment}

Dawis and Lofquist (1984) took time to discuss what characteristics individuals bring to their work environment. They categorized these characteristics into two "aspects of personality: structure and style" (Dawis \& Lofquist, 1984, p. 25). The personality structure is the preference of conditions a person brings with them, while the style is what connects the interactions with the environment (Dawis \& Lofquist, 1984). There are two dimensions of importance when it comes to structure; the first is abilities, which 
represents a person's skill, and the second dimension is value, which represents a person's needs (Dawis \& Lofquist, 1984).

The connection between characteristics and dimensions are determined "by both the employer and the employee," according to Dawis and Lofquist (1984, p. 25). In order to recruit and retain employees, employers must recognize the important role satisfaction has (Dawis \& Lofquist, 1984). It "means the meeting of employee requirements. In this manner, employer and employee jointly determine the abilities, values, and style dimensions that will be found to be relevant in the work setting" (Dawis \& Lofquist, 1984, p. 25).

According to Dawis and Lofquist (1984), "personality style takes account of how an individual with a particular personality structure will interact with an environment" (p. 31). The characteristics of responding is what makes up the dimensions of personality style (Dawis \& Lofquist, 1984). The work personality has four different dimensions of personality style: celerity, pace, rhythm, and endurance (Dawis \& Lofquist, 1984). The dimension that connects to person-environment fit theory is that of endurance. "The longer an individual continues to interact with the environment, the higher the individual's endurance" (Dawis \& Lofquist, 1984, p. 31). In this sense, endurance can be judged on the basis of "long tenure on jobs or in organizations" (Dawis \& Lofquist, 1984, p. 31).

Dawis and Lofquist (1984) described the theory of work adjustment as the "correspondence between individual and environment" (p. 54), which implies that there is a "harmonious relationship between individual and environment" (p. 54). The relationship is suitable, consonance, and "reciprocal or complimentary" between the 
person and environment (Dawis \& Lofquist, 1984, p. 54) and is the basis of personenvironment fit theory. While people bring their own expectations to the environment, the environment has its own expectations of the person (Dawis \& Lofquist, 1984).

\section{Rural Schools}

Students learn more when they are taught by highly qualified teachers. According to The Southeast Center for Teacher Quality (2004), highly effective teachers are the most important factor in student achievement. The No Child Left Behind Act (2002) increased requirements for teacher certification, which creates a disincentive for teachers to seek employment in a rural school because it would require teachers to obtain multiple certifications to meet the needs of the district. For example, one in 10 teachers in a rural district studied taught 10 or more courses on average (Kaden, Patterson, \& Adams, 2016). "This increased focus on teacher quality has emphasized the need for effective teacher recruitment and retention” (Beesley, Atwill, Blair, \& Barley, 2010, p. 1), especially for rural schools (Elfers \& Plecki, 2006; Ulferts, 2016).

When looking at the Schools and Staff Survey, teacher recruitment and retention are related (Beesley et al., 2010). Schools that report poor recruiting are almost twice as likely to have a high turnover rate (Ingersoll, 2001; Luekens, Lyter, \& Fox, 2004; Strizek, Pittsonberger, Riordan, Lyter, \& Orlofsky, 2006). According to Kaden et al. (2016), the average retention rates in "rural districts $(<77 \%)$ are significantly lower than average retention rates" of $94 \%$ (p. 136). Rural and urban schools face some similar challenges, such as a high population of students living in poverty, but rural schools often have additional obstacles such as lower salaries, remote locations, and poor access to health care. 
Strizek et al. (2006) stated that rural schools shared filling vacancies was either very difficult or unable to be filled when compared to all schools. It appears that "school size was a significant factor in retention" (Beesley et al., 2010, p. 2). Principals in rural schools utilized a variety of methods to fill positions. According to Beesley et al. (2010) some of those methods included alternative licensure or a higher placement on the salary scale. Urban schools also have the opportunity to certificate paraprofessionals or establish partnerships with higher education institutions to fill vacancies, where rural schools do not always have those types of luxuries. In some rural schools "principals worry about simply filling vacancies, not hiring the best teachers. The inability of some rural...schools to attract applicants leaves principals in the precarious position of having to hire whoever walks through the door, or failing to offer some courses" (Maranto \& Shuls, 2012, p. 32). Jimerson (2003) stated that rural schools often end up "hiring underprepared teachers, more out-of-field teaching assignments, larger classes, fewer advanced course options, less coordinated curriculum, less experienced teaching staff, and fragmented professional development" due to their inability to recruit highly qualified teachers (p. 13).

According to Ingersoll (2001), rural schools have the highest rate of teacher turnover. Kaden et al. (2016) stated that several variables can impact teacher attrition, such as "work conditions and teaching responsibilities; community integration and living conditions; teaching assignments; elements of job satisfaction; and teachers' plans for the future" (p. 131). Low teacher retention, which is dominant in rural schools, negatively impacts student achievement (Kaden et al., 2016; Maranto \& Shuls, 2012; Ulferts, 2016). When students repeatedly have novice teachers, it stunts their academic performance 
(Huling, 1998). The National Commission on Teaching and America's Future (2007) stated that high teacher attrition in rural schools caused inequitable concentrations of unqualified, inexperienced teachers.

Other areas of concern arise when teacher attrition is high. "Teacher recruitment efforts and retention woes add to the economic distress of rural schools," shared Ulferts (2016, p. 14). Because rural schools have to invest time and money into new teachers, it affects the financial efficiency of the district (Eberhard, Reinhardt-Mondragon, \& Stottlemyer, 2000). Furthermore, Kim and Loadman (1994) stated that if district administration better understood the role job satisfaction has in teacher retention, "there may be an opportunity to intervene in those cases where job satisfaction is marginal or low, or where it is high, this may be a way to maintain it at a high level" (p. 10). Huysman (2008) agreed, stating that teacher job satisfaction highly correlated with retention. According to Ulferts (2016), it "has positive implications for both student achievement and school quality" (p. 14). "If the factors contributing to rural teacher job satisfaction can be identified, recruitment efforts may attract better qualified teachers and reduce teacher attrition, resulting in increased student achievement and economic savings for rural districts" (Ulferts, 2016, p. 14).

The school community also plays a large role in rural schools, as school buildings in rural areas are often symbolic. They quickly become a sporting center or dining hall for community events (Nordic Council of Ministers, 2010). Ulferts (2016) believed that the community is one of the most influential factors in determining teacher retention. He goes so far as to state that hiring administrators should put weight on whether the applicants have a rural background or not and that questions to find out should be 
included in the hiring process. Rural teachers can feel isolated; the school community should make a concerted effort to include teachers, especially new ones into their social construct (McClure \& Reeves, 2004; Zhang, 2008). Ulferts (2016), stated that "if there are not recruitment marketing programs in place, then rural educational leaders will want to put them in place" (p. 21). They should be specific for hard to fill vacancies, sustainable, and community-rooted (Ahearn, Harmon, \& Sanders, 2005; Kaden et al., 2016; McClure \& Reeves, 2004), as well as emphasized the benefits of a rural school, such as manageable class sizes, genuine relationships, and involvement in the decisionmaking process (Lemke, 1994; Malloy \& Allen, 2007; Sargent 2003). Unfortunately, rural communities find themselves comfortable with a rotating line up of teachers, according to Kaden et al. (2016). "If rural leaders understand the factors that contribute to teachers choosing to teach and remain teaching in rural areas, then rural districts can improve their teacher recruitment and retention, as well as reduce the costs associated with additional professional development of new staff, and accelerate student achievement" (Ulferts, 2016, p. 15).

"Not only do rural schools need to attract highly qualified teachers, rural schools must also ensure effective teachers are retained" (Ulferts, 2016, p. 14). When a teacher leaves a rural school district, it makes a greater negative impact than it does in larger schools (Beesly et al., 2010). For example, "if a math teacher leaves, ...there may be no math department until another teacher is hired" (p. 1). Rural schools have a more difficult time recruiting teachers than other hard-to-staff schools. Rural administrators need recruitment and retention strategies that are specific to rural schools and need to develop a better understanding of what influences teachers to accept and remain teaching in the 
smallest schools. Beesley et al. (2010) stated, ultimately "rural-specific challenges in teacher recruitment and retention are most successfully addressed with rural-specific solutions" (p. 8).

\section{Barriers to Implementation}

There are methodological concerns when looking to study person-environment fit. "The objective measurement of the person's skills, abilities, and needs and of the environment's demands and resources continues to elude us. The assessment of subjective measures of [person] and [environment]" requires more development (Caplan, 1987, p. 263). Along with data collection development, another area that needs to be systemically developed for implementation is the questions being asked during the hiring process. In a survey given to administrators across the nation, many shared that they had little guidance from professionals in the field of human resources when creating interview questions (Grove, 2008). Rarely were administrators trained in how to conduct effective interviews. Administrators also often "limit the amount of attention given to information exchanged during the hiring process" (Ellis et al., 2017, p. 452). According to Ellis et al. (2017), administrators who struggle to recruit interested teachers often hire anyone who meets the job requirements. This means that administrators will need to willingly rethink their hiring process, or the implementation of best practices will go unused.

\section{Rethinking Current Practices}

Ultimately, "these results also have implications for management practice...fit matters to applications, recruiters, and employees. It influences their attitudes, decision, and behaviors in the work domain" (Kristof-Brown et al., 2005, p. 325). It is important 
for managers to explicitly discuss their moral principles (Trevino, Hartman, \& Brown, 2000) with applicants. Kristof-Brown et al. (2005) shared that

from the beginning of the recruitment process through long-term employment, managers should pay attention to how clearly they are communicating work unit and organizational values. This should aid in the attraction, hiring, and retention of individuals who share those values and are inspired by an organization that reinforces them. (p. 326)

"Districts, principals, and teacher-candidates all need quality information to assess the fit between the teacher candidate and the needs of the school. This process is critically important to hiring effective teachers and, therefore, to increasing student learning" (Podolsky et al., 2016, p. 29). According to Podolsky et al. (2016), "studies suggest that district and school practices related to hiring and supporting teachers influence teachers' decisions to enter, stay in, or leave the profession. In other words, schools and districts that adopt effective hiring practices are, unsurprisingly, more successful at attracting and hiring effective teachers, leading to greater rates of schoolwide achievement.

\section{Summary}

"Although teachers may be more motivated by a desire to 'do good' than some other workers, altruism alone is not enough to attract high-ability candidates to the profession and keep them in the classroom" (Podolsky et al., 2016, p. 9). This process of retaining quality teachers begins with recognizing that people want to work for an organization that will respond to their needs for useful work (Bolman \& Deal, 2013). School leaders need to develop a thoughtful hiring process, communicate the 
organization's values, and respond to their employees' needs. Investing in these practices will lower teachers' intention to leave (Vekeman et al., 2018). By finding the best teacher fit for their school district, leaders ensure not only longterm success for the employees, but also create long-term success for the organization (Bolman \& Deal, 2013). 


\section{SECTION FOUR}

CONTRIBUTION TO PRACTICE 


\section{Contribution to Practice}

The researcher will present the findings of this research study to the Missouri Association of Rural Education (MARE) at their annual conference. MARE is an organization made up of teachers, administrators, intuitions of higher education, and many others. All those involved have a particular interest in working with rural school districts. MARE provides a variety of services to organizations that belong. They contract "for services such as board policy manuals, legal advice, financial assistance, preparation of board member training materials, [and] administrative searches" among other things (Missouri Association of Rural Education, 2019a). They also provide board training and possible scholarships as a benefit to their members.

MARE's annual conference has "numerous workshops featuring current topics of interest to the rural education community" (Missouri Association of Rural Education, 2019a). The conference is held at the Lake of the Ozarks in the late part of October or early part of November. To lead a workshop at the conference, the researcher will need to contact MARE's director for an application. 


\section{RETENTION \\ Induction Programs}

\section{Amanda Minear, Ed.D.}

Hi everyone, my name is Amanda Minear. I am a recent graduate of the University of Missouri's Doctor of Education program. I am currently an administrator in Columbia Public Schools, but I have recently been a K-12 principal at a district with an enrollment of approximately 125 students in mid-Missouri. I'm here today to talk about teacher retention as it pertains to rural public schools. I want to start my presentation today by sharing two different numbers with you. The first is... 


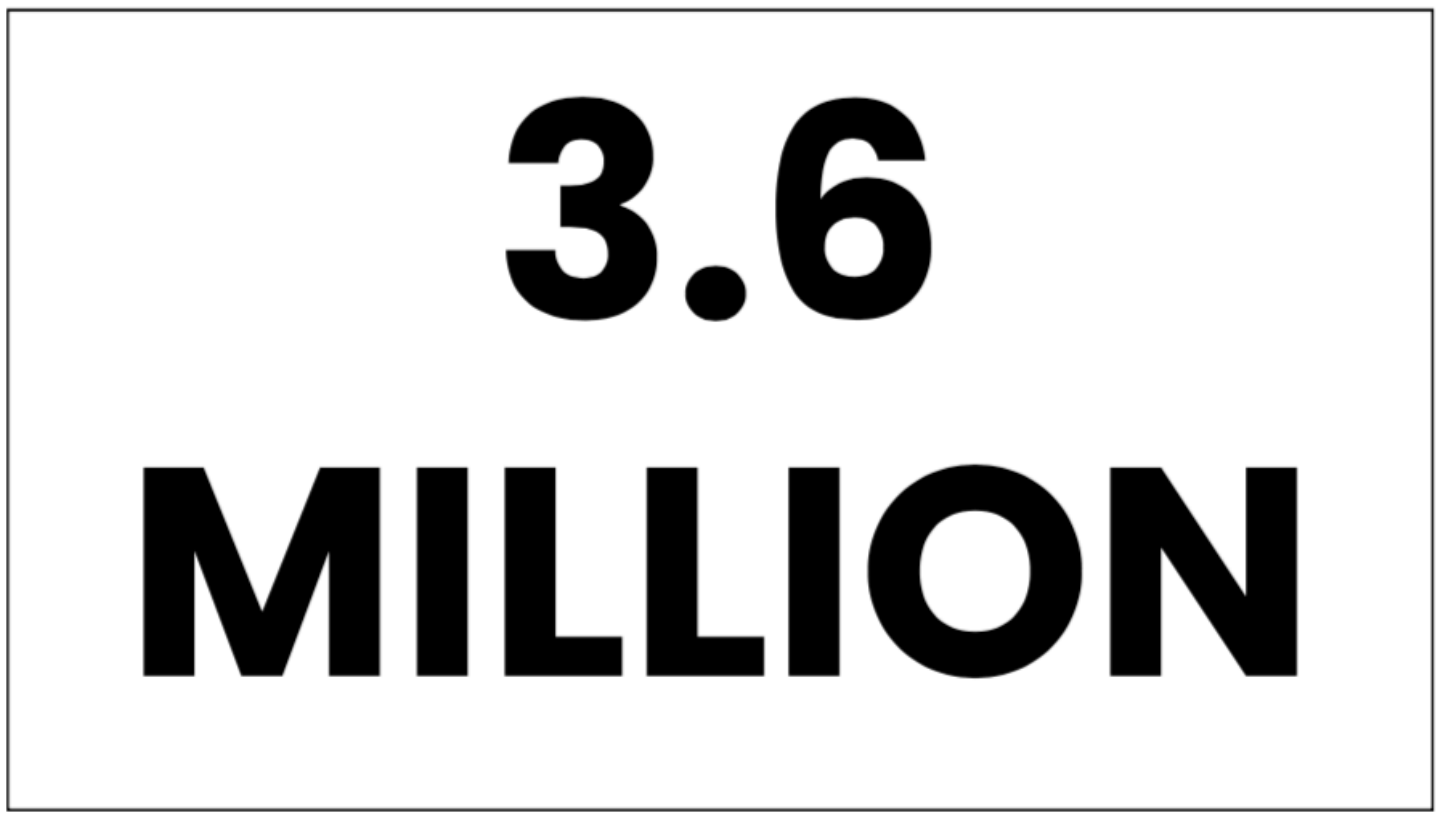

3.6 million. That's the number of public school teachers who moved to a new school in 2015. That's the same as replacing one in six teachers across the United States for the next school year (Feng, 2017).

As you all know, the cost of teacher attrition is significant. The research show there is a "a positive relationship between teaching experience and a variety of other student outcomes, such as reductions in student absences, increases in students' time spent reading for pleasure, and decreases in classroom disruptions. High rates of turnover mean that fewer teachers develop the experience that often leads to compounding academic benefits for their students" (Podolsky, Kini, Bishop, \& Darling-Hammond, 2016, p. 8).

That makes this number very scary. The next slide is going to share another number that is more specific to you as rural superintendents. 


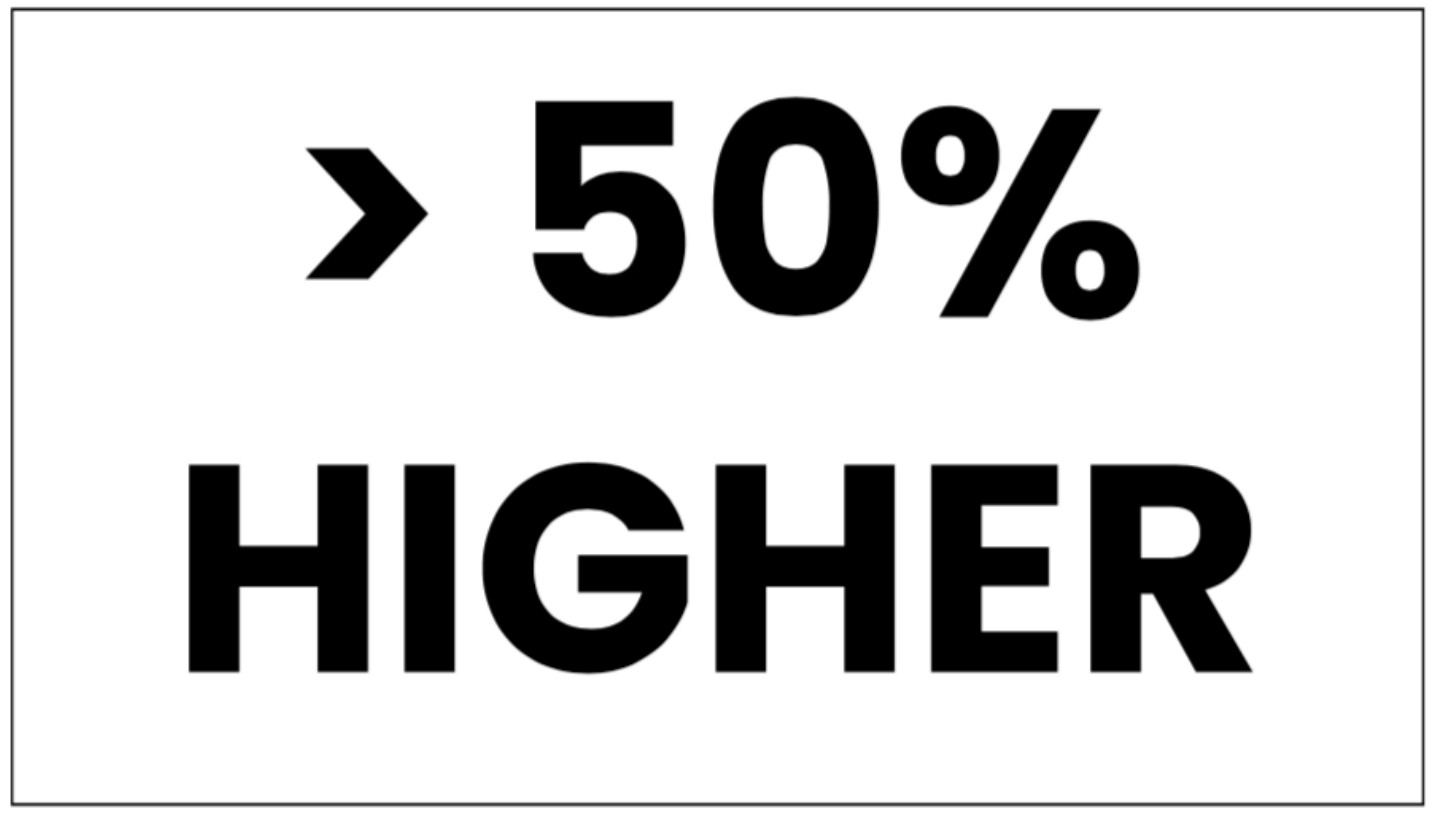

Teacher turnover is over $50 \%$ higher in rural communities than in others (Podolsky et al., 2016).

This is in part to declines in both professionals entering the field of education and the low rates of teacher retention.

Teacher attrition is often caused by challenging work environments (Mulvahill, 2018). In some schools, that could be because they are under-resourced and/or serve a high percentage of students living in poverty (Podolsky et al., 2016). 


\section{IMPACT ON RETENTION}

In order to make environments like these less challenging for teachers, administrators must recruit teachers who are prepared and have a comprehensive approach in place to retain them (Carver-Thomas \& Darling-Hammond, 2017; Podolsky, Kini, Bishop, \& Darling-Hammond, 2016).

Misfit is unpleasant and stressful, causing employees to be motivated to resolve their misfit through turnover (Edwards \& Shipp, 2007; Yu, 2009).

There are other factors that impact retention rates. One of those factors are misfit. Ultimately, a suitable fit can increase student achievement (Bohndick, Rosman, Kohlmeyer, \& Buhl, 2018; Etzel \& Nagy, 2016; Li, Yao, Chen, \& Wang, 2013). By viewing employees as arbiters of fit, people can manage their fit and reduce negative consequences of the misfit (Edwards \& Shipp, 2007; Follmer, Talbot, Kristof-Brown, Astrove, \& Billsberry, 2018). 


\section{How many of you have struggled to fill a teacher vacancy?}

How many of you have filled a vacancy with someone who wasn't the best quality? ...maybe because they were the only applicant? Trust me, you aren't the only ones.

According to the research, hard-to-staff schools, which are urban and rural schools, "consequently often struggle to attract talented, well-prepared teachers, hiring individuals who have not yet completed (and sometimes have not yet begun) their preparation. Many studies have documented the disproportionate concentration of underprepared and inexperienced teachers in" (Podolsky et al., 2016, p. 23) rural schools. 


\section{STATEMENT OF THE PROBLEM}

The National Center for Education Statistics (1995) stated that schools with the lowest enrollments experience the highest teacher turnover rates.

Teacher attrition has a negative compounding effect on students' academic achievement, as well as a variety of other outcomes (Podolsky et al., 2016).

In recent years, teacher shortages have risen to a crisis level (Podolsky et al., 2016). Rural schools especially face continual teacher shortages, as they have the highest teacher attrition rate among schools (Ingersoll, 2001; Podolsky et al., 2016).

As mentioned before, the cost of teacher attrition is noteworthy. Teachers who stick around in their school district are "much more expert at diagnosing student learning, differentiating instruction to address gaps while accelerating progress, and supporting a range of social, emotional, health, and psychological needs, in addition to sometimes complex academic needs" (Podolsky et al., 2016, p. 21). I know that this information is nothing new to you all. 


\section{What elements of person- environment fit theory appear to be important to retention of teachers in rural public schools?}

I mentioned the idea earlier that misfit can cause attrition. I used this as a reason to look at teacher turnover through the lens of person-environment fit theory. This theory is "broadly defined as the compatibility between an individual and a work environment that occurs when their characteristics are well matched" (Caplan, 1987).

There are two ways to look at person-environment fit theory. The first is that "organizations select persons who will best meet the demands of the job" and the second is that "prospective employees want to find organizations which make use of their particular abilities and meet their specific needs" (Caplan, 1987, p. 248). It's basically a supply versus demand theory.

A poor organizational fit often has a low employee retention rate (Caplan, 1987). Solutions mentioned include "tailoring the employees' abilities to the demands of the organization" or "altering the organization's resources to meet the needs of the employee" (Caplan, 1987, p. 258). I don't know about you all, but I think it's pretty difficult to drastically change the resources you have available in a school setting. That means we need to look at what we can do to tailor the teacher's ability to work in your school-environment.

Person-environment fit assesses characteristics of the work environment and the influences it has on individuals. Through this theoretical framework, "it is clear that fit matters" (Kristof-Brown, Zimmersonman, Johnson, 2005, p. 315). And I think we can all agree on that. The better the fit, the more satisfied the individual is at their job (van Vianen, 2018), which then creates better outcomes for our students. 


\section{PURPOSE OF THE STUDY}

The purpose of this qualitative study is to gain an understanding of the elements of person-environment fit theory and their impact on retention in rural public schools. Finding the right fit not only focuses on the individual, but also the organization's characteristics (Georg, 2009).

According to the research, the individuals' abilities need to match the demands of the organization in order to have a positive effect on academic outcomes (Bohndick et al., 2018; Edwards, Caplan, \& van Harrison, 1998; Edwards \& Shipp, 2007; Reis \& McCoach, 2000).

So, the big question is, what if they don't? What if your teachers' abilities do not match the demands of your organization? 


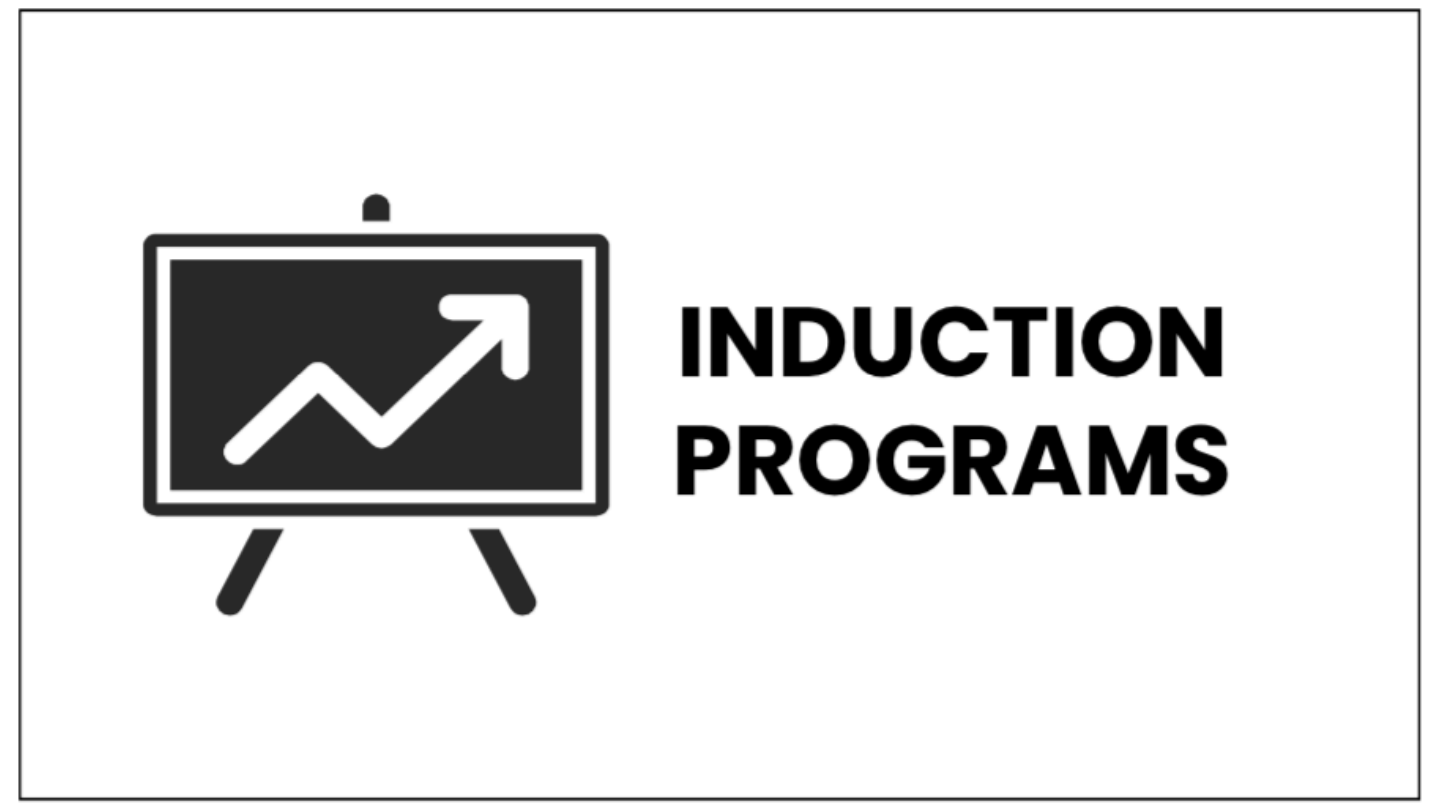

You can use induction programs to increase employees' abilities before the school year even begins!

While there is plenty of research on teacher attrition, there is little information available about how the implementation of the hiring process is related to retention within rural school districts. Each potential teacher has a different experience during the hiring process. Little was known about how that experience influences their fit (Yu, 2009).

Until now, of course! 


\title{
DESIGN OF THE STUDY
}

\author{
Site Selection
}

Five Rural Districts in Missouri

- 2016 MSIP Score of 90 or Higher

- Similar 2104 and 2015 MSIP Scores

- 10+ Years Experience for Professional Staff in 2018

All schools had a K-12 enrollment under 500.

- 102, 288, 213, 287, 413; an average of 261 students

So, let's talk a little bit about the design of my study.

Five rural school districts were selected to participate. Schools were first narrowed down by their geographical location and next by their school enrollment.

I think it's important to note that while the study says the enrollment has to be under 500, which seems very large compared to probably many of your schools, there's really only one large rural school in my study. You can see the enrollment sizes listed, with the average enrollment of the five schools being 261.

The next thing looked at was the MSIP score from 2016. I wanted it to be 90 or higher, with 2014 and 2015 scores being similar. Lastly, the average years of experience for professional staff needed to be 10 or more. I believe that in looking for these two things, this showed that the schools were successful academically, long-term. 


\section{DESIGN OF THE STUDY}

\section{Participant Selection}

Process:

- Superintendent Approval

- Five Administrator and 15 Teacher Interviews

\section{Teacher Criteria:}

- Five or More Years Experience in the District

- Successful as Deemed by Principal or Superintendent

When it came to selecting participants, I first reached out to superintendents for approval. They helped put me in contact with their principals, and teachers who taught five or more years in their district successfully.

I did not micromanage the definition of successful. I felt like success might look different in each setting and I trusted the professional judgement of the administration. 


\section{DESIGN OF THE STUDY}

Data Collection and Analysis

Process:

- Interviews Were Held Via Zoom

- They Were Recorded and Transcribed

- All Information is Confidential \& Pseudonyms Were Used

- Transcripts Were Coded and Themes Emerged

COVID-19 put a wrench in my original plans, so I ended up meeting with participants via Zoom. Each interview lasted between 30 and 60 minutes. I recorded the interviews and then transcribed them. We'll discuss the themes momentarily. 


\section{DESIGN OF THE STUDY}

\section{Limations, Assumptions, and Future Research}

Limitations: The study is limited to five school district across the state of Missouri.

Assumptions: The researcher was mindful of reflexivity.

Future Research: Data on the impact administrator retention has on teacher retention would be insightful.

There were some limitations and assumptions that I was aware of during this study, as well as some future research opportunities that presented themselves.

The first is the limitation that this study was confined to only five school districts across the state of Missouri. In most studies, the more participants from a wider area, the better.

Next, I had to be aware of reflexivity, which is the impact my background and experiences had on shaping my interpretation of the data being collected (Creswell, 2014). I used a peer to debrief with to add validity to the study.

Based on the information gathered from participants, it would be interesting to see the impact administrator retention has on not only rural schools, but in all types of settings. 


\section{FINDINGS}

\section{Person-Group Fit}

- Committees

- The Community

- Administration

Induction Programs

- Community

- Mentoring

So, let's discuss the findings of my study. Under the umbrella of person-environment fit theory, it gets broken down into four areas. One of those is person-group fit.

Groups in the sense of this study includes coworkers, committees, parents, business owners, students, organizations, administrators, and anyone else connected to the school. According to my participants, this clearly had a large impact on the retention of teachers.

One teacher summed this up nicely by sharing how much each different group within the entire school-community makes an impact on his decision to stay. He said, "It's a family affair. And that's because we grew to love the town, the school, everything about it."

A theme that falls under the idea of person-group fit is induction programs. To my surprise, these had a significant impact on most teachers when they began teaching in their current district.

They shared how many of their first connections were encouraged by induction programs at the start of their first school year in their district. 


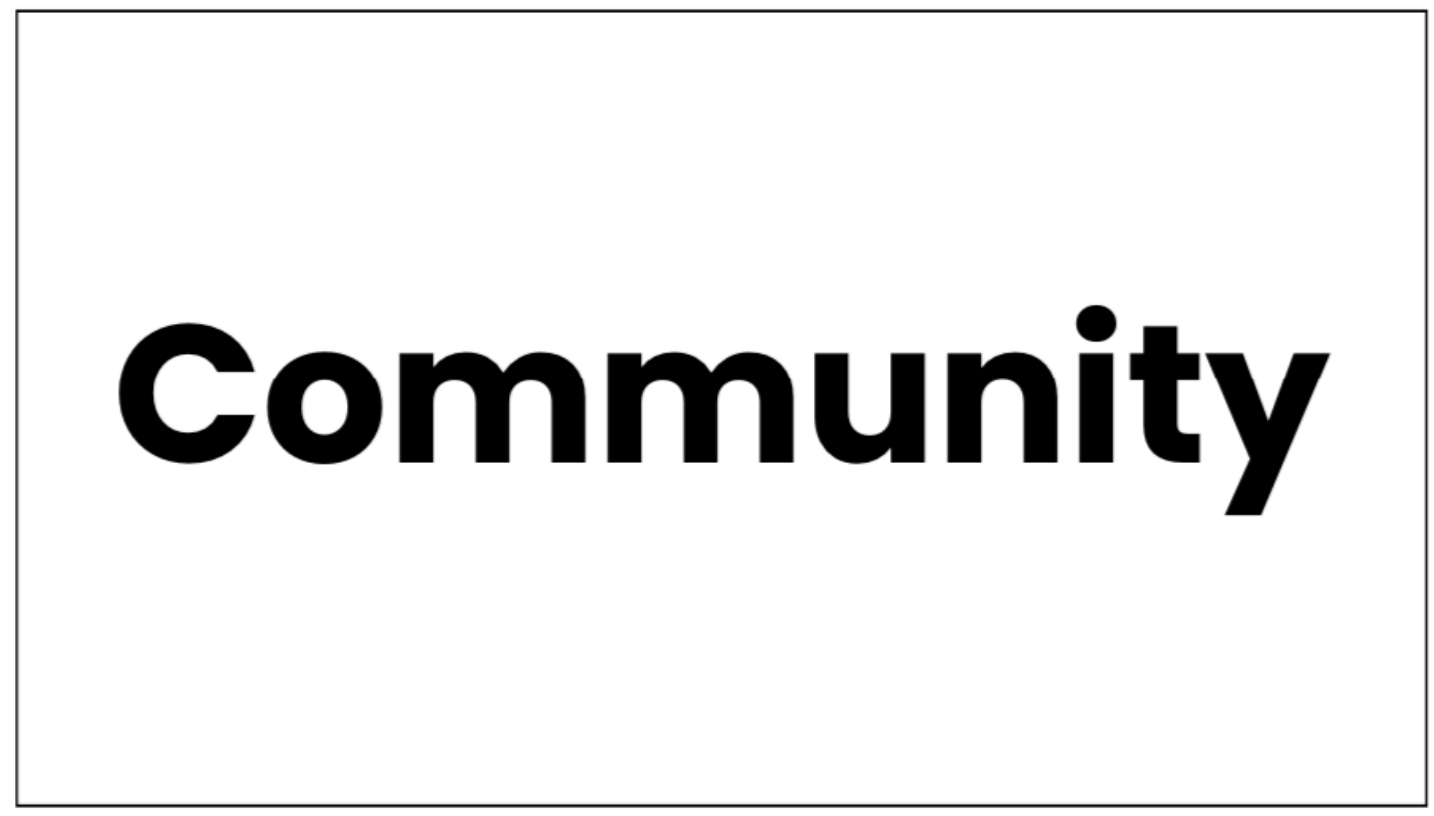

Successful induction programs used those first couple of days to introduce their new teachers not only to staff, but also to community members. 


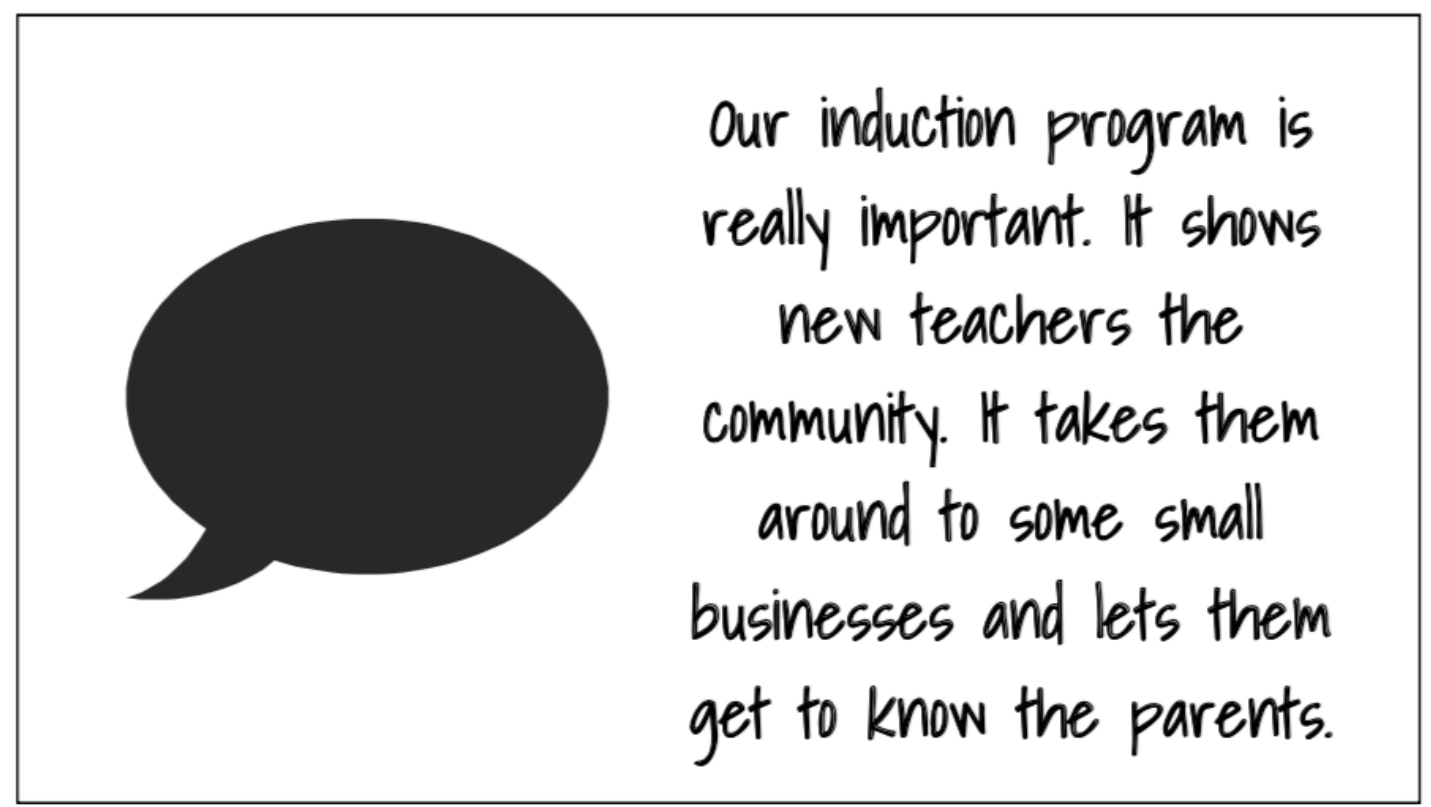

Many districts believe that bridging the gap between the school and community is part of their duty to new teachers. 


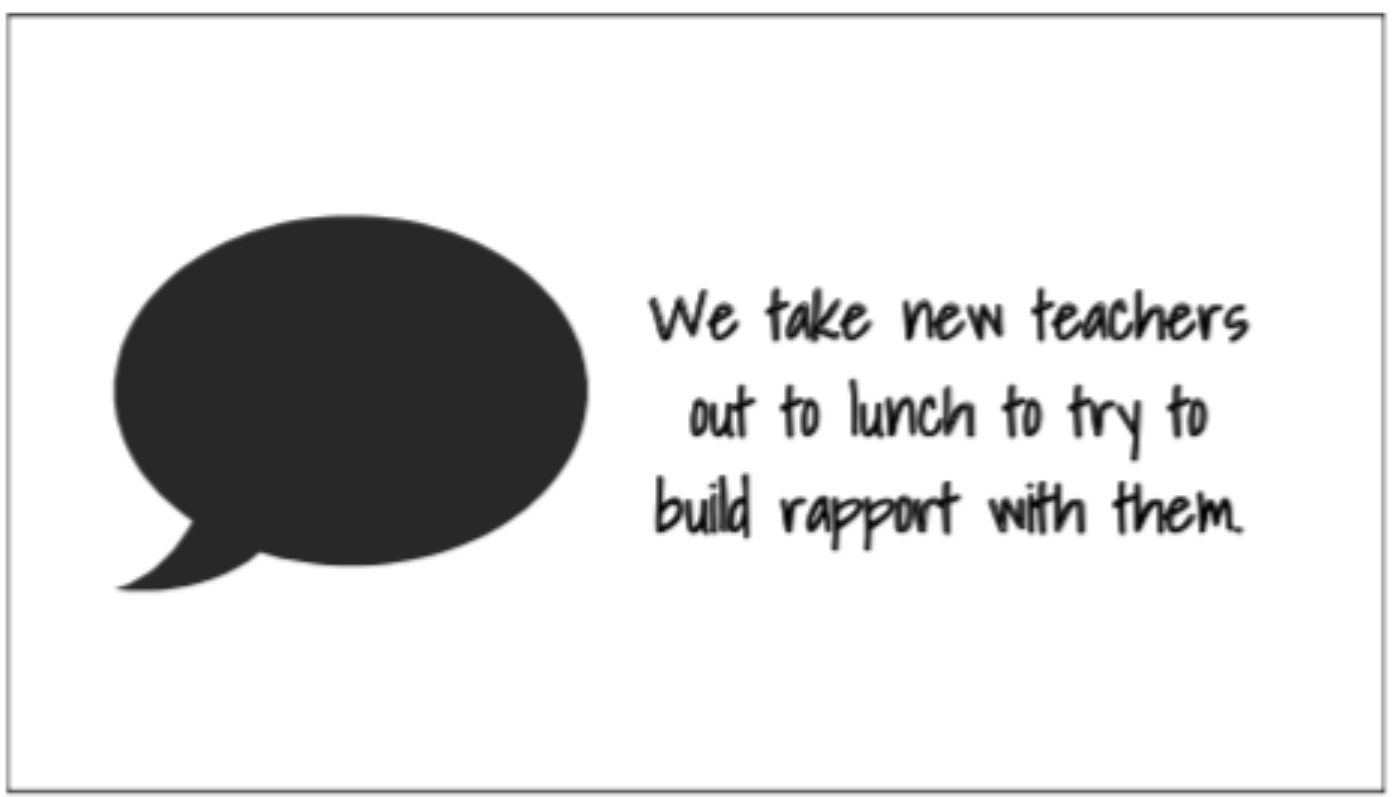

This principal shared that she is intentional with new teachers during their induction program. She believes this small gesture starts building a solid foundation with her new teachers. 


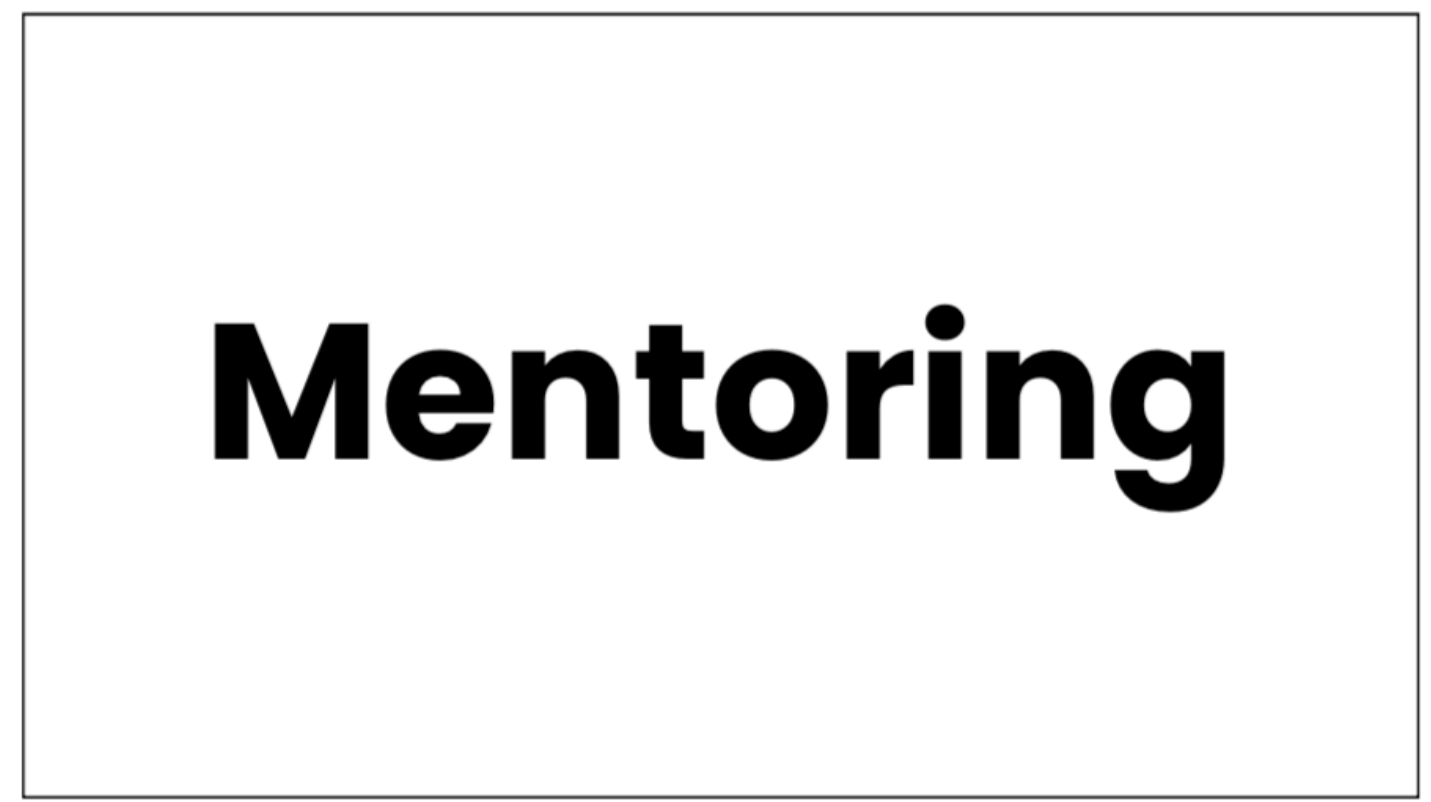

Mentoring may be one of the biggest takeaways from this entire study. Successful school districts seem to have extensive mentoring, which begins with the induction program. 


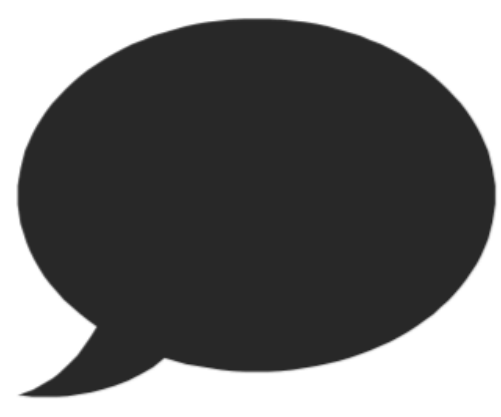

\section{Training, orientation, and mentorship, they are just so crucial to the induction process. It helps you get to know everything.}

The teacher who shared this quote remembered how impactful her mentor was from day one. This participant is now on the building's leadership team that leads new teacher induction. She was adamant that mentoring is a necessary component for new teachers to be successful. 


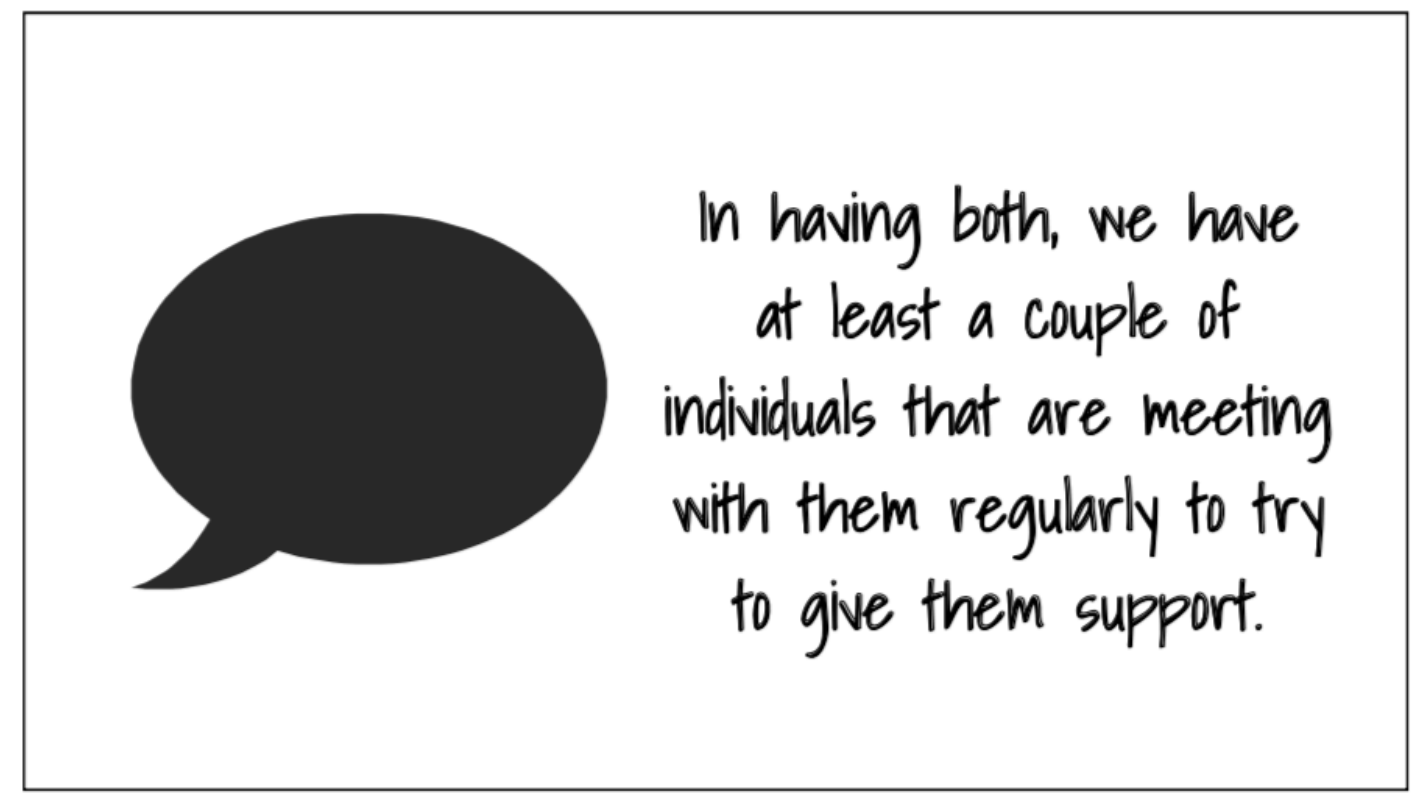

Districts assign mentors in different ways, but what I found is that most try to hook new teachers up with someone who teaches similar content, as well as someone who teaches the same age of students.

This particular principal shared this quote about using vertical and horizontal mentors. 


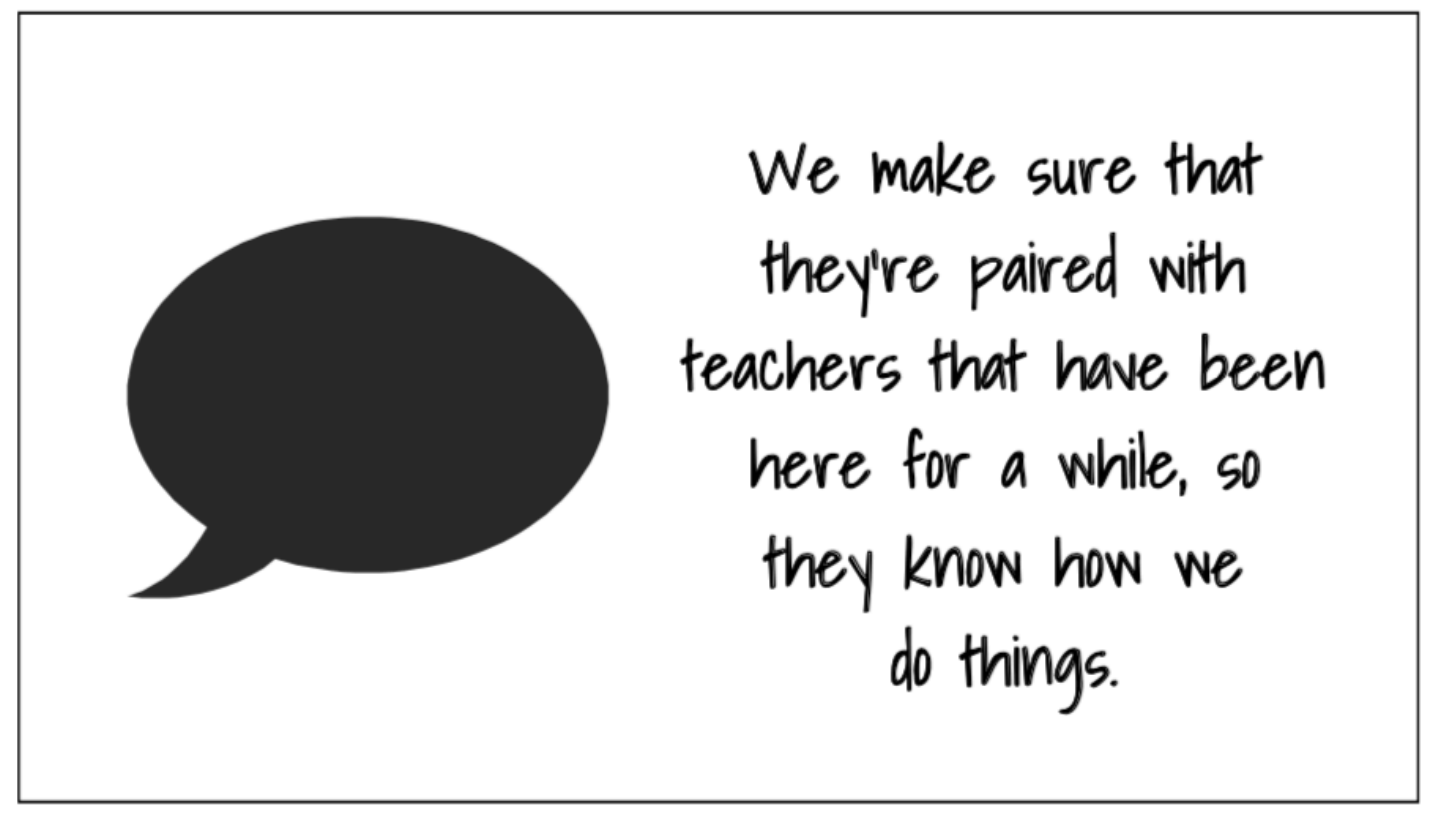

Mentors play an important role in their district. They are veteran teachers who are charged with passing down important information, including rituals and symbolic traditions. In doing so, these mentors are helping new teachers be successful.

This principal says that he makes a point to always pair someone up with teachers who have been in their building the longest. 


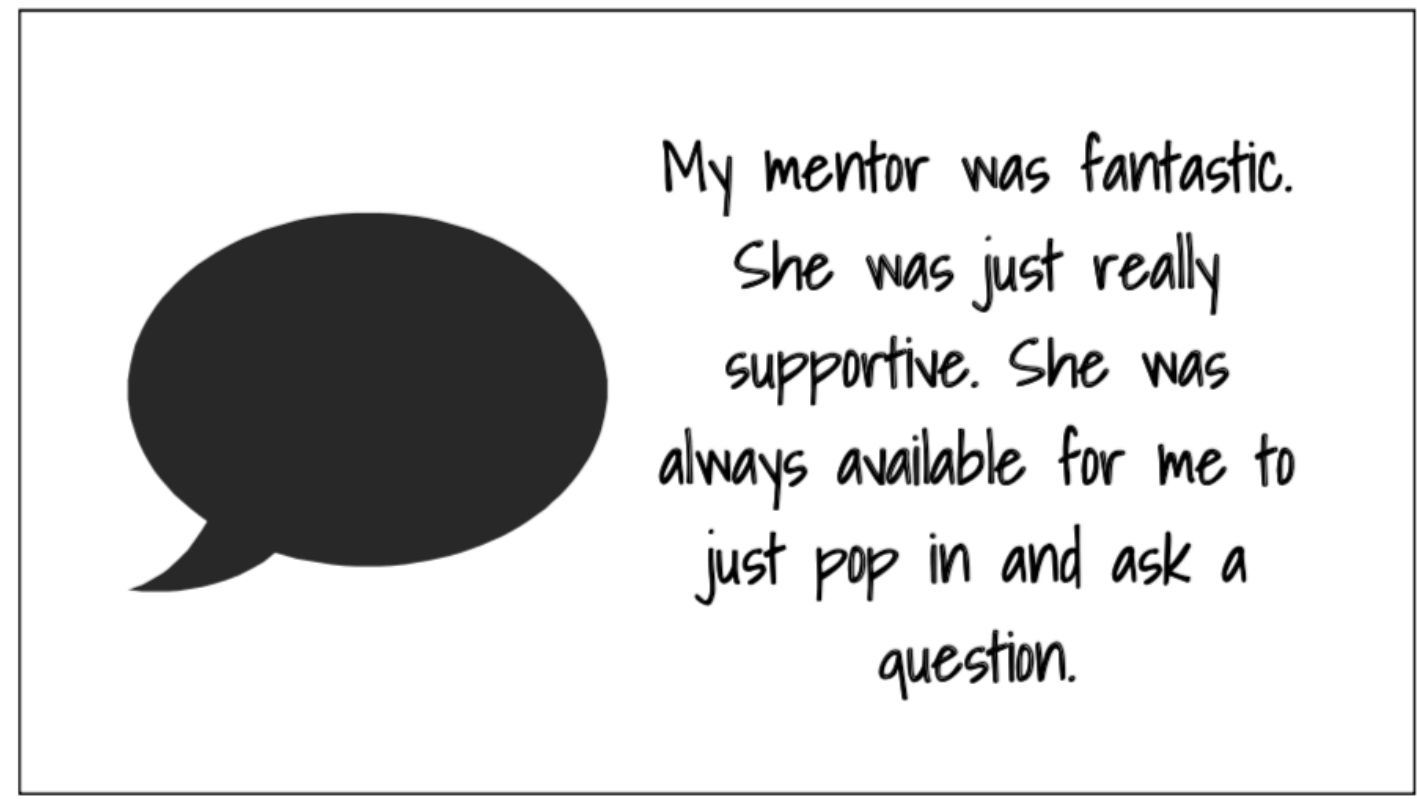

The last big point that was made by participants was ease of access to mentors. Most mentors are meeting more frequently than they are assigned, but only if they are close in proximity or have similar schedules.

This teacher appreciated that she had unlimited access to her mentor. They worked in the same hallway and had a common plan time. 


\section{IMPLICATIONS}

Having a systematic process in place to give new teachers information on how to be successful in your district will take time, money, and training (Ellis, Skidmore, \& Combs, 2017).

Administrators who want to raise student achievement must remove these barriers in the retention process. You'll have to allow new teachers an opportunity to better understand the organization (Ellis et al., 2017).

When teachers participate in an information-poor hiring process, their fit is usually lower than expected (Ellis, Skidmore, \& Combs, 2017).

Do you remember that we were looking at fit as a supply versus demand theory? 


\section{RECOMMENDATIONS}

\section{Induction Program}

Training:

- Organization

- Professional Development

\section{Collaboration:}

- Community

- Mentors

Induction programs will help new teachers understand the demands of the school, while training them will supply them with what they need to be successful.

My recommendation is that if you need to raise your teacher retention rates, that you take a look at your induction program.

While it will take some time and effort to organize, you won't have to drastically change the resources you have available in your school setting.

In the next few slides, I am going to break down these four points. 


\section{RECOMMENDATIONS}

\section{Organizing Your Induction Program}

Considerations:

- Use a Committee

- Have Time to Speak

- Take Them to Lunch

In order to organize the professional development, utilize the teacher leaders within your building. Most districts have a professional development or leadership committee.

Work with this committee to make sure they allow time for administration to speak. This is an opportunity for you or your principal to set the tone for the upcoming year. Make the message impactful. This is something that teachers new to your district will remember.

Also, make sure the committee allows for a day of long lunch. Providing the administrators time to take new teachers to lunch will help build rapport. 


\title{
RECOMMENDATIONS
}

\section{Providing Professional Development}

\author{
Considerations:
}

- Technology, Grading, and Curriculum

- Strengths In District

- Outside Resources

Have this committee decide what aspects need included in the training. The most discussed items in the study included technology needs, grading practices, and curriculum support. The committee will have to decide how much time to allow on these areas and any other areas that may be necessary.

They will also need to look at who to contact in order to schedule accordingly. Ideally, they will be able to connect with teachers already in the district and use their strengths to help train the new teachers. This not only provides an opportunity to increase the retention of the person providing the professional development, but also save the district money by not having to pay for professionals to come in.

Sometimes it may be necessary to pay for a professional to come in from a company. While this may not be ideal on a budget, I would like to point out that research shows that investing time and money into new teachers will provide more dividends than deductions in the long run. 


\section{RECOMMENDATIONS}

\section{Connecting to the Community}

Considerations:

- Take Them to Lunch

- Provide a Tour

- Bring in the PTO

As previously mentioned, taking new teachers out to lunch can be beneficial. It not only allows for administrators to build rapport, it also allows new teachers to see what the community looks like. It provides the foundation to connections to the community, as well as spreading a positive reputation, which another part of my study found to be a significant recruitment tool.

Another great opportunity to connect with the community is through a tour of the town. This can be provided by your local bus drivers and a verteran staff member that is most familiar with the community. Again, this is a great way to retain that veteran staff members, as well as providing a connection to your new teachers.

An easy way to get new teachers connected with the community is by bringing in the parent-teacher organization to participate in the induction program. This could be for a relationship building activity, providing a tshirt, or serving breakfast. This is another way to build your positive reputation. 


\title{
RECOMMENDATIONS
}

\section{Collaborating with Mentors}

\author{
Considerations:
}

- Provide Everyone a Mentor

- Horizontal and Vertical

- Provide a Schedule

Last, but certainly not least, the planning committee should connect new teachers to mentors. Districts should consider providing mentors to every teacher even if they are not mandated too.

Most schools used in my study provided a horizontal and vertical mentor. They tried to pair someone up by subject and by grade level. The more support you can provide, the more likely you are to retain your new teachers.

Administrators should provide a schedule of times mentors can get together to collaborate. Building time into your calendar year will help ensure that you have a meaningful, long-term program.

Ultimately, creating a sound induction program will tailor the teacher's ability to work in your school-environment, thus making them a better fit leading to increased retention rates and more academic success for your students. 


\section{REFERENCES}

Bohndick, C., Rosman, T., Kohlmeyer, S., \& Buhl, H. (2018). The interplay between subjective abilities and subjective demands and its relationship with academic success. An application of the person-environment fit theory. Higher Education, 75, 839-854. doi: $10.1007 / \mathrm{s} 10734-017-0173-6$

Caplan, R. (1987). Person-environment fit theory and organizations: Commensurate dimensions, time perspectives, and mechanism. Journal of Vocational Behavior, 31, 248-267

Carver-Thomas, D. \& Darling-Hammond, L. (2017). Teacher tumover: Why it matters and what we can do about it. Palo Alto, CA: Learning Policy Institute.

Creswell, J. (2014). Research design: Qualitative, quantitative, and mixed method approaches. Thousand Oaks, CA: SAGE

Edwards, J., Caplan, R., \& van Harrison, R. (1998). Person-environment fit theory. Conceptual foundations, empirical evidence and directions for future research. In C. Cooper (Ed.), Theories of organizational stress (pp. 28-67). Oxford, UK: Oxford University Press.

Edwards, J. \& Shipp, A. (2007). The relationship between person-environment fit and outcomes: An integrative theoretical framework. In C. Ostroff \& T. Judge (Eds.), Perspectives on organizational fit (pp. 209-258). New York, NY: Erlbaum.

Elis, C., Skidmore, S., \& Combs, J. (2017). The hiring process matters: The role of person-job and person-organization fit in teacher satisfaction. Educational Administration Quarterly, 53(3), 448-474. doi:10.1177/0013161X16687007 


\section{REFERENCES}

Etzel, J. \& Nagy, G. (2016). Students' perceptions of person-environment fit. Do fit perceptions predict academic success beyond personality traits? Joumal of Career Assessment, 24(2), 270-288. doi:10.1177/1069072715580325

Feng. L. (2017) Stemming the tide: Are public school districts keeping the best and brightest teachers? Retrieved from https://www.brookings.edu/blog/brown-center-chalkboard/2017/06/01/stemming-the-tide-are-public-school-districts-keeping-the-bestand-brightest-teachers/

Follmer, E., Talbot, D., Kristof-Brown, A., Astrove, S., \& Billsberry, J. (2018). Resolution, relief, and resignation: A qualitative study of responses to misfit at work. Academy of Management Journal, 61(2), 440-465.

Georg, W. (2009) Individual and institutional factors in the tendency to drop out of higher education: A multilevel analysis using data from the Konstanz Student Survey. Studies in Higher Education, 34(6), 647-661. doi: 10.1080/03075070802592730

Ingersoll, R. M. (2001). Teacher turnover and teacher shortages: An organizational analysis. American Educational Research Joumal, 55(3), 499-534.

Kristof-Brown, A, Zimmersonman, R., \& Johnson, E. (2005). Consequences of individuals' fit at work A meta-analysis of person-job. person-organization, person-group, and person-supervisor fit. Personnel Psychology, 58(2), 281-342. 


\section{REFERENCES}

Li, Y., Yao, X., Chen, K., \& Wang. Y. (2013). Different fit perceptions in an academic environment: Attitudinal and behavioral outcomes. Journal of Career Assessment, 21(2), 163-174. doi:10.1177/1069072712466713

Mulvahill, E. (2018) Why teachers quit. Retrieved from https://uww.weareteachers.com/why-teachers-quit/

The National Center for Education Statistics (1995). Which types of schools have the highest teacher tumover? Retrieved from https://nces.ed.gov/pubs95/web/95778.asp

Podolsky, A., Kini, T., Bishop, J., \& Darling-Hammond, L. (2016). Solving the teacher shortage: How to attract and retain excellent educators. Palo Alto, CA: Learning Policy Institute.

Reis, S. \& McCoach, D. (2000). The underachievement of gifted students: What do we know and where do we go? The Gifted Child Quarterly, 44(3), 152-170. doi:10.1177/001698620004400302

van Vianen, A. (2018). Person-environment fit: A review of its basic tenets. The Annual Review of Organizational Psychology and Organizational Behavior, 5, 75-101.

Yu, K. (2009). Affective influences in person-environment fit theory: Exploring the role of affect as both cause and outcome of p-e fit. Joumal of Applied Psychology, 94(5), 1210-1226. doi:10.1037/a0016403 


\section{Questions?}

Thank you!

You can contact me at:

- (573) 356-2355

- alf8tc@missouri.edu

- @A_MinearLMS

That's it for my presentation. Thank you for being here today!

You can contact me if you have any specific questions or would like help setting up your induction program.

Does anyone have any questions that I can answer now? 
SECTION FIVE

CONTRIBUTION TO SCHOLARSHIP 


\section{The Impact Satisfaction Has on Teacher Retention in Rural Schools}

Teacher attrition is negatively impacting the success of students in rural public schools at an unprecedented rate. In order to retain teachers, school administrators must know what makes teachers stay in successful school districts. This article makes the connection between satisfaction and the impact the work environment has on it. It analyzes the school-community as a whole and recommends a practical solution to increase retention rates among teachers in rural public schools.

\section{Introduction}

In 2015, one in six teachers were replaced for the following school year due to attrition (Feng, 2017). According to Podolsky, Kini, Bishop, and Darling-Hammond (2016), there is "a positive relationship between teaching experiences and a variety of student outcomes" (p. 8). Some of those outcomes include reductions in absences, an increase in time spent reading, and a decrease in disruptions in the classroom. These outcomes can impact the entire school. That means the cost of teacher turnover can have significant compounding effects on students.

Teacher attrition is even more costly in hard-to-staff schools, such as rural public schools across the state of Missouri. Teacher turnover is over $50 \%$ higher in schools that teach students living in poverty when compared to others (Podolsky et al., 2016). There are a variety of reasons why teachers leave their schools. Teachers cited dissatisfaction as an important reason for leaving their positions (Carver-Thomas \& Darling-Hammond, 2017). Teachers who have higher satisfaction also have less stress, more trust, and better team cohesion. Schools also see less attrition, along with better performance in these individuals (Harold, Oh, Holtz, Han, \& Giacalone, 2016; Kristof-Brown, Zimmersonman, and Johnson, 2005; Mulki, Jaramillo, \& Locander, 2006; Naus, Van Iterson, \& Roe, 2007; Oh, Guay, Kim, Harold, Lee, Heo, \& Shin, 2014). 
Dissatisfaction can also be caused by mistfit. Misfit occurs when the person and environment lack connection on a variety of levels (Follmer, Talbot, Kristof-Brown, Astrove, \& Billsberry, 2018; Harrison, 2007; Kristof, 1996; Schneider, 1987; Schneider, Goldstein, \& Smith, 1995). "Misfit is generally conceived as the negative end of the fit continuum, and is associated with discomfort or incompatibility" (Follmer et al., 2018, p. 441). Meaningful insight on practices that lead to misfit can be provided by individuals who have experienced it (Billsberry, Ambrosini, Moss-Jones, \& Marsh, 2005; Follmer et al., 2018; Kristof-Brown \& Guay, 2011; Shipp \& Jansen, 2011).

According to Mulvahill (2018), teachers leave their school when it becomes a challenging environment for them to work in. Hard-to-staff schools are often the most under-resourced schools and usually serve the highest number of students living in poverty (Podolsky et al., 2016). In order to make environments like these less challenging for teachers, administrators must have a comprehensive approach in place to retain them (Carver-Thomas \& Darling-Hammond, 2017; Podolsky et al., 2016).

\section{Significance of the Study}

The purpose of this qualitative study is to gain an understanding of the connection between satisfaction and retention of rural public school teachers. According to van Vianen (2018), satisfaction and occupational commitment are connected. Ellis, Skidmore, $\&$ Combs (2017) found that teacher satisfaction has been declining, noting that in 2012, only $39 \%$ of teachers indicated they were satisfied, which is a drop from 2008 when $62 \%$ said they were satisfied.

Experts agree that maintaining a positive hedonic balance is a goal for all employees (Yu, 2009; Buss, 2000; Larsen, 2000). Yu (2009) continued to share that 
employees with low job satisfaction often have behavioral responses that involve quitting. Vekeman, Devos, Valcke, \& Rosseel (2018) shared the important role that managers have in this. Mangers with styles that "support autonomy needs, reward structures or performance systems that provide feedback about one's competency, or activities that satisfy relatedness needs" are likely to increase satisfaction (p. 826)." The idea of job satisfaction resulting in retention has been supported in various educational literature (Perrachione, Rosser, \& Petersen, 2008).

\section{Research Question}

The researcher posed the following research question: Why do teachers who have successfully worked long-term in a rural school district flourish?

\section{Theoretical Framework}

Caplan's (1987) person-environment fit theory was used as the theoretical framework for this study. Kristof-Brown et al. (2005) stated person-environment fit is "broadly defined as the compatibility between an individual and a work environment that occurs when their characteristics are well matched" (p. 281). Within the personenvironment fit theory, there are four types of fit. The two that will be looked at the most in this study are: (1) person-supervisor fit where the individual's cultural values and those of their manager are the same; and (2) person-group fit, where the individual's cultural values meet those of their specific work group (Kristof-Brown et al., 2005).

There are a number of variables to analyze when considering person-environment fit. Turnover, the most studied variable, is influenced by a variety of fit types (KristofBrown et al., 2005). The fit types are all connected to behaviors within a work experience, according to Kristof-Brown et al. (2005). In the sense of this study, person- 
environment fit will show how employees will stay with organizations that meet their needs (Caplan, 1987).

Overall, person-environment fit assesses characteristics of the work environment and the influences it has on individuals. Through this theoretical framework, "it is clear that fit matters" (Kristof-Brown et al., 2005, p. 315). The better the fit, the more satisfied the individual is at their job (van Vianen, 2018). Person-environment fit has research compiled around Holland's (1997) model of vocational personality types and Dawis and Lofquist's (1984) theory of work adjustment.

Holland's (1997) work focused around helping people find practical ideas to "select jobs, change jobs, and attain vocational satisfaction" (p. 1). The theory is centered on a variety of factors including behavior and personalities (Holland, 1997). The idea is that when people choose a vocation, there is a reason either within their personality or history, so "it follows that each vocation attracts and retains people with similar personalities" (Holland, 1997, p. 10). Another principle is that "vocational satisfaction, stability, and achievement depend on the congruence between one's personality and the environment in which one works" (Holland, 1997, p. 11). People "are more likely to perform well at a vocation in which [they] 'fit' psychologically" (Holland, 1997, p. 11). According to Dawis and Lofquist, (1984), the connection between characteristics and dimensions are determined "by both the employer and the employee" (p. 25). In order to recruit and retain employees, employers must recognize the important role satisfaction has (Dawis \& Lofquist, 1984). It "means the meeting of employee requirements. In this manner, employer and employee jointly determine the abilities, 
values, and style dimensions that will be found to be relevant in the work setting" (Dawis \& Lofquist, 1984, p. 25).

\section{Design of the Study}

\section{Site and Participant Selection}

Five school districts from across the state of Missouri were selected for this study. The first criteria included a K-12 enrollment of under 500 students. The largest district used in this study had 473 students, while the smallest was 102 . The average enrollment from all five schools was 272.6 students. Each district also had an academic achievement score of 90 or higher on their Missouri School Improvement Program score card in 2016. The 2014 and 2015 MSIP scores also need to be comparable. The districts used in this study had an average academic achievement score of 92.2 in 2016.

Districts also needed to have an average of 10 or more years of experience with their teachers. This is listed on their score card as well. The average years' experience for the participating districts was 13.38 years. For individuals, teachers must have been teaching in the district they were currently in for five or more years. A total of 20 participants were used in the study. Five participants were principals, one from each school, and the other 15 were teachers. The average years of experience for the 15 teachers was 24.4 years.

\section{Data Collection}

Individual interviews were the method used for data collection. Interviews took place during the COVID-19 outbreak, thus causing interviews to be held through an online platform called Zoom. All interviews were approximately 45 minutes in length. Participants who met the initial requirements were then narrowed down based on the 
success their principal witnessed. The researcher contacted participants individually to schedule interviews. Participation in the study was voluntary and confidential.

Pseudonyms were used for this study. All interviews were recorded and transcribed. All data collection followed the University of Missouri's Institutional Review Board ethical requirements.

\section{Data Analysis}

Following Creswell's (2016) steps for the process of coding, the researcher transcribed interviews verbatim. The researcher then read all transcripts and coded each one. Creswell (2016) indicates once all of the codes have been listed, they can then be put into groups "to eliminate redundancy and overlap" (p. 162). Once themes emerged in the coding process, the researcher determined the themes most beneficial for answering the research question. Themes and sub-themes will be addressed in the findings. Patterns that emerged validate the findings of this qualitative study (Merriam \& Tisdell, 2016).

\section{Findings}

\section{Long-Term Success}

The research question asked why teachers who have successfully worked longterm in a rural school district flourish. In order to know why teachers stay long-term, we need to know what keeps them satisfied. Some participants suggested that successful teachers are not ever completely satisfied, that they are often always looking for opportunities to grow. While, in a sense, this may be true, many participants shared in detail what keeps them at satisfied with their current school. 


\section{Answer to the Research Question}

\section{Support Creates Satisfaction}

Almost every participant stated that support is a main factor in their success. Caleb believes that "it all starts with administration." Nora confirmed that when her administrators are supportive, she is the most satisfied. Her administrators support her at times when she has questions or student issues. Many teachers feel like they can share concerns with their administrators. According to Nora, teachers want to know that "their ideas matter."

Mark, a principal at Marshall City, agreed. He has no doubt that being supported is going to keep his teachers satisfied. Cooper also believes it boils down to support. Teachers "need to feel like, at the end of the day, they can teach and do what's best, and they're going to have administrator support, no matter what." He believes that his role as the principal is to "be the person that teachers can count on, that's going to be here for you."

It is also important for administration to know when teachers are not satisfied, so some teachers described that. Cara said that people "definitely know if [teachers] aren't satisfied." Julia and Elena confirmed this. Julia shared that you can actually hear the difference between a satisfied and an unsatisfied staff. Elena thinks you know if people are satisfied by just visiting with them. When teachers are not happy, they talk about anything and everything that upsets them. Julia believes you can tell the staff is satisfied when "the kids seem happy. When the staff is happy, it usually translates to them."

Ultimately, teacher participants confirmed that if they are unsatisfied they would be looking for a new school to work at. Nina also said she knows New Falls is a good fit 
for her because she is happy. 'I haven't really wanted to go somewhere else. Matt feels similarly. He said the teacher retention lets you know if teachers are satisfied. In Marshall City, the people Matt is close with have extremely high satisfaction. They are not looking for other jobs. Mark understands that. "If [teachers] don't feel like they're getting supported by the administration, they're not going to want to be here."

\section{Recommendations}

If vocational satisfaction improves one's ability to fit into their work environment (Holland, 1997), districts must find ways to satisfy their teachers in order to increase retention. This study found that teachers look for support throughout each school year not only from their administrators, but also their coworkers and the community. That means school districts must be more intentional in connecting new teachers with those supports. A recommendation that encompasses all of those aspects is an induction program.

\section{Induction Program}

In order to retain teachers in rural public schools, districts have to satisfy their teachers. This study found that teachers look for support throughout each school year not only from their administrators, but also their coworkers and the community. That means school districts have to be more intentional in connecting teachers new those supports. A recommendation that encompasses all of those aspects is an induction program.

In order for induction programs to be successful, someone within the district must take on the lead role to organize the agenda. Melissa said that her principal was in charge of the teacher induction program at Marshall City. Her principal "went through everything with us." Another option is to have a group of teacher leaders organize the program. Natalie's school has a professional development committee that she works with 
to support new teachers. When organizing an induction program, it's important to think about each aspect of what can support a new teacher.

To begin, it's important to show new teachers the entire school-community. Joel thinks that their induction program is "really important. It shows the new teachers the Joanstown community. It takes them around to some small businesses and lets them get to know the parents." He said that giving his new teachers a visual of the community they are serving helps prepare them for the start of school. Many districts believe that bridging the gap between the school and community is part of their duty to new teachers.

Next, the induction program should connect new teachers to a mentor teacher who is a veteran in the building. Participants shared that many interactions were first encouraged by the teacher induction programs set up at each school. Mya said that she thinks that mentoring is a necessary component for new teachers to be successful. "Training, orientation, and mentorship, they are just so crucial to the induction process. [It helps] you get to know everything.” Pairing new teachers up with veterans can help them adapt to their surroundings. Many participants shared that they had more than one traditional mentor. Often times, their administrators paired them up with someone on their grade level team, as well as someone who worked within their curriculum department. Mark said they do this because then "we have at least a couple of individuals that are meeting with them regularly to try to give them support." Participants mentioned that there were scheduled meetings for mentors and new teachers, but most met fairly regularly to have day-to-day discussions.

Lastly, building time in to connect with teachers is important, but districts should build time in with administrators also. Nora attended back to school professional 
development the day before the rest of the staff came back for part of her induction process. Something that has always stuck with her is that she met the superintendent on her first day. He came in to speak to the new teachers and that had an impact on her. Natalie said that they also take new teachers out to lunch to try to "build rapport with them."

\section{Limitations, Assumptions, and Future Research}

A limitation to the study is that each principal was not necessarily the one to hire the teacher being interviewed. It would be ideal to expand the study to include only schools where the current principal was at the school when the vacancy was open. This would allow the principal to discuss supports that led the teacher to continued success in their school. Another limitation is this study is specific to the state of Missouri. All five schools used in this study are from rural areas in Missouri. Expanding the study to include rural schools from other states would make the study results more generalized for all rural schools.

The researcher was mindful of the role reflexivity could have had in this study. Reflexivity is understanding the impact our background and experiences have on shaping the interpretation of the data being collected. Evaluating bias was a priority (Creswell, 2014) to the researcher. The researcher graduated from a rural school district in northern Missouri and was a principal in a rural school in central Missouri. As an educator, having her own thoughts and opinions about teachers and rural school districts, the researcher was careful to disregard those during data analysis. Merriam and Tisdell (2016) reminded the researcher to regularly "think about your biases that you brought into the study." (p. 208). 
A couple future research opportunities arose during this study. Many teacher participants discussed principals they used to work for in the district they are currently working in. While this study looks at the environment as a whole supports the teacher, it would be interesting to see the impact administrator retention has on retention of teachers in rural schools. Rural schools are considered a hard-to-staff school along with urban schools. Completing this study with urban schools and then comparing the results might help states such as Missouri update their teacher preparation or administrator certificate programs to better prepare staff to go into one of the two school settings.

\section{Conclusion}

Teachers are leaving their schools at an unprecedented rate. This qualitative study about teacher retention allowed participants to share their stories on what causes success in rural public schools across the state of Missouri. Through data analysis, one main theme emerged: Support Creates Success. This along with data collected on induction programs, allowed the researcher to recommend a comprehensive induction program to support teacher success and retain them long term. Knowing that satisfaction can increase retention, district administrators must make a concerted effort to keep teachers satisfied. 


\section{References}

Billsberry, J., Ambrosini, V., Moss-Jones, J., \& Marsh, P. (2005). Some suggestions for mapping organizational members' sense of fit. Journal of Business and Psychology, 19, 555-570.

Buss, D. (2000). The evolution of happiness. American Psychologist, 55, 15-23.

Missouri is rural? Missourian. Retrieved from https://www.columbiamissourian. com/visuals/graphics/how-much-of-missouri-is-rural/pdf_ba6e98a6-3af4-11e9a75a-5b6864d87feb.html

Caplan, R. (1987). Person-environment fit theory and organizations: Commensurate dimensions, time perspectives, and mechanism. Journal of Vocational Behavior, $31,248-267$.

Carver-Thomas, D. \& Darling-Hammond, L. (2017). Teacher turnover: Why it matters and what we can do about it. Palo Alto, CA: Learning Policy Institute.

Creswell, J. (2014). Research design: Qualitative, quantitative, and mixed method approaches. Thousand Oaks, CA: SAGE

Creswell, J. (2016). 30 essential skills for the qualitative researcher. Thousand Oaks, CA: SAGE

Dawis, R. \& Lofquist, L. (1984). A psychological theory of work adjustment: An individual-differences model and its applications. Minneapolis, MN: University of Minnesota Press.

Ellis, C., Skidmore, S., \& Combs, J. (2017). The hiring process matters: The role of person-job and person-organization fit in teacher satisfaction. Educational Administration Quarterly, 53(3), 448-474. doi:10.1177/0013161X16687007 
Feng, L. (2017) Stemming the tide: Are public school districts keeping the best and brightest teachers? Retrieved from https://www.brookings.edu/blog/browncenter-chalkboard/2017/06/01/stemming-the-tide-are-public-school-districtskeeping-the-best-and-brightest-teachers/

Follmer, E., Talbot, D., Kristof-Brown, A., Astrove, S., \& Billsberry, J. (2018). Resolution, relief, and resignation: A qualitative study of responses to misfit at work. Academy of Management Journal, 61(2), 440-465.

Harold, C., Oh, I., Holtz, B., Han, S., \& Giacalone, R. (2016). Fit and frustration as drivers of targeted counterproductive work behaviors. The Journal of Applied Psychology, 101, 1513-1535.

Harrison, D. (2007). Pitching fits in applied psychological research: Making fit methods fit theory. In C. Ostroff \& T. Judge (Eds.), Perspectives on organizational fit, 389-416. Chicago, IL: Lawrence Erlbaum Associates.

Holland, J. (1997). Making vocational choices: A theory of vocational personalities and work environments. Englewood Cliffs, NJ: Prentice Hall.

Kristof, A. (1996). Person-organization fit: An integrative review of its conceptualizations, measurement and implications. Personnel Psychology, 49(1), $1-49$.

Kristof-Brown, A. \& Guay, R. (2011). Person-environment fit. In S. Zedeck (Ed.), APA handbook of industrial and organizational psychology, 3-50. Washington, D.C.: American Psychological Association. 
Kristof-Brown, A., Zimmersonman, R., \& Johnson, E. (2005). Consequences of individuals' fit at work: A meta-analysis of person-job, person-organization, person-group, and person-supervisor fit. Personnel Psychology, 58(2), 281-342.

Larsen, R. (2000). Toward a science of mood regulation. Psychological Inquiry, 11, 129 $-141$.

Merriam, S. \& Tisdell, E. (2016). Qualitative research: A guide to design and implementation (4th ed.). San Francisco, CA: Jossey-Bass.

Mulki, J., Jaramillo, F., \& Locander, W. (2006). Emotional exhaustion and organizational deviance: Can the right job and a leader's style make a difference? Journal of Business Research, 59, 1222-1230.

Mulvahill, E. (2018) Why teachers quit. Retrieved from https://www.weareteachers. com/why-teachers-quit/

Naus, F., Van Iterson, A., \& Roe, R. (2007). Value incongruence, job autonomy, and organization-based self-esteem: A self-based perspective on organizational cynicism. European Journal of Work and Organizational Psychology, 16(2), 195219.

Oh, I., Guay, R., Kim, K., Harold, C., Lee, J., Heo, C., \& Shin, K. (2014). Fit happens globally: A meta-analytic comparison of the relationships of person-environment fit dimensions with work attitudes and performance across East Asia, Europe, and North America. Personnel Psychology, 67, 99-152.

Perrachione, B., Rosser, V., \& Petersen, G. (2008). Why do they stay? Elementary teachers' perceptions of job satisfaction and retention. The Professional Educator, $32(2), 25-41$. 
Podolsky, A., Kini, T., Bishop, J., \& Darling-Hammond, L. (2016). Solving the teacher shortage: How to attract and retain excellent educators. Palo Alto, CA: Learning Policy Institute.

Schneider, B. (1987). The people make the place. Personnel Psychology, 40, 437-453.

Schneider, B., Goldstein, H., \& Smith, D. (1995). The ASA framework: An update. Personnel Psychology, 48, 747-773. Retrieved from http://dx.doi.org/10.1111/ j.1744-6570.1995.tb01780.x

Shipp, A. \& Jansen, K. 2011. Reinterpreting time in fit theory: Crafting and recrafting narratives of fit in media res. Academy of Management Review, 36, 76-101.

van Vianen, A. (2018). Person-environment fit: A review of its basic tenets. The Annual Review of Organizational Psychology and Organizational Behavior, 5, 75-101.

Vekeman, E., Devos, G., Valcke, M., \& Rosseel, Y. (2018). Principals' configuration of a bundle of human resource practices. Does it make a difference for the relationship between teachers' fit, job satisfaction and intention to move to another school? Educational Management Administration \& Leadership, 46(5), 820-840.

Yu, K. (2009). Affective influences in person-environment fit theory: Exploring the role of affect as both cause and outcome of p-e fit. Journal of Applied Psychology, 94(5), 1210-1226. doi:10.1037/a0016403 
Appendix A

\section{Participants Setting}

Column 1: Rural School's Pseudonym

Column 2: School's 2019-2020 Enrollment

Column 3: 2016 MSIP-5 Score

Column 4: 2015 MSIP-5 Score

Column 5: 2014 MSIP-5 Score

Column 6: 2018 Average Staff Years of Experience

\begin{tabular}{|c|c|c|c|c|c|}
\hline School & Enrollment & 2016 MSIP & 2015 MSIP & 2014 MSIP & Years \\
\hline Joanstown & 213 & 95.7 & 89.9 & 90.7 & 14.6 \\
\hline New Falls & 473 & 97.1 & 98.6 & 89.3 & 12.4 \\
\hline Easton & 287 & 94.3 & 94.2 & 94.6 & 10.7 \\
\hline Coalsville & 102 & 90.6 & 96.0 & 93.5 & 15.1 \\
\hline Marshall City & 288 & 95.7 & 97.1 & 92.9 & 14.1 \\
\hline
\end{tabular}




\section{Appendix B}

\section{Participants}

Column 1: Rural School's Pseudonym

Column 2: Participant's Pseudonym

Column 3: Participant's Role

Column 4: Participant's Years in District

\begin{tabular}{|c|c|c|c|}
\hline School & Participant & Role & Years \\
\hline Coalsville & Caleb & 7-12 Social Studies Teacher & 6 \\
\hline Coalsville & Cara & Special Education Teacher & 9 \\
\hline Coalsville & Cooper & Principal & 1 \\
\hline Easton & Elena & High School Math and Science Teacher & 7 \\
\hline Joanstown & Julia & Title I Teacher & 11 \\
\hline Joanstown & Joel & Principal & 3 \\
\hline Marshall City & Melissa & Middle School English Teacher & 8 \\
\hline Marshall City & Matt & High School Social Studies Teacher & 14 \\
\hline Marshall City & Mark & Principal & 16 \\
\hline Marshall City & Mya & Kindergarten Teacher & 5 \\
\hline New Falls & Nora & $4^{\text {th }}$ Grade Teacher & 23 \\
\hline New Falls & Nina & $5^{\text {th }}$ Grade Teacher & 17 \\
\hline New Falls & Natalie & Principal & 30 \\
\hline
\end{tabular}


SECTION SIX

SCHOLARLY PRACTITIONER REFLECTION 


\section{Scholarly Practitioner Reflection}

A scholarly practitioner uses research to create full circle experiences of collecting, interpreting, and using data in a leadership role (Creswell, 2014).

Understanding that data can be used to address root causes in schools allows leaders to put systems in place to specify a course of action (Datnow \& Park, 2014; London, Sanchez, \& Casrewchini, 2016). This data can "inform the development of proactive interventions and support strategies to help students succeed" (Parnell, 2018, p. 52). Leaders must understand the influence they have over this setting. They can tie initiatives to their district's mission (Cardoza \& Gold, 2018), as well as make significant changes to the system itself (Johnson, 2018), which can all have major effects on the staff working in that environment (Becker, 1995).

\section{Leadership in Practice}

At the beginning of the University of Missouri's Doctor of Education (EdD) program, all students took the StrengthsQuest assessment to determine what qualities they possessed. My strengths were achiever, harmony, significance, positivity, and winning others over (woo). I have many takeaways from the EdD, but learning how to best utilize these strengths in my place of work may be one of the biggest.

My strengths allow me to be a servant leader for my school-community. A servant leader "focuses on developing employees to their fullest potential" in a variety of areas (Liden, Wayne, Zhao, \& Henderson, 2008, p. 162). This style of leadership forms strong relationships with employees that often extend outside of the organization according to Liden et al. (2008). I often find myself working with staff on a variety of projects. 
Sometimes these projects are related to our work with students and other times it is helping the individual teacher achieve personal goals.

Being a servant leader means being supportive. Northouse (2016) shared that supportive style leaders treat followers as equals and go out of their way to make the workplace a pleasant environment. Leaders who put people first "create an atmosphere of trust where employees can feel comfortable and secure" (Northouse, 2016, p. 45). Lencioni (2012) shard that strong teams trust one another, engage in unfiltered conflict around ideas, commit to decisions and plans of action, hold one another accountable, and focus on the achievement of the collective results. It is my mission to create an environment where teachers believe in our team. I find myself working harder to put supports in place for our adults than I do for students. Through this program though, I have come to realize that by laying the foundation for adults, I am actually setting my students up for success as well.

The ability to work well with my teachers comes from my human skills. The human skill is defined as "the abilities that help a leader to work effectively with followers, peers, and superiors to accomplish the organization's goals," (Northouse, 2016, p. 45). Leaders with a high human skill are "sensitive to the needs and motivations of others," (Northouse, 2016, p. 45); because of this, I will continue to keep people at the heart of all my decisions.

\section{People Focused}

Every organization has a culture. Culture is about people being placed in the right position under influential leadership they believe in (Bolman \& Deal, 2013). My teachers believe in me now more than they ever have. Thanks to the EdD, I know that leaders play 
a sizeable role in developing the culture of a group of individuals as described by Levi (2017) and Schein (1993/2005). Every day I attempt to produce a positive environment for my teachers. In an organization that functions as such, a culture of commitment will be reflected. It will promote participation, open communication, and stability (Bolman \& Deal, 2013). It is my goal to create a culture that embraces equity, inclusion, and harmony.

This type of collective approach makes an organization stronger by enhancing team effectiveness in working towards a common goal. Having a common goal unites members within the same organization (Levi, 2017). I am deliberate when it comes to setting goals and gathering participants. I purposefully integrate multiple, diverse perspectives during collaboration, which can increase an organization's effectiveness, according to Johnson (2018). Having a variety of perspectives will bring creativity and innovation to the forefront when working with a team (Bolman \& Deal, 2013). In education as we know it, we often ask teachers to think outside the box. Having diverse perspectives and innovative ideas will increase the likelihood of achieving our goals. Prior to the EdD, I had a set group of teachers I would ask to complete school tasks. I now understand just how important it is to be aware of those being asked to have a seat at the table.

\section{Action Driven}

I now have what Ettling (2012) described as "a predisposition to educate for change" (p. 536). Within each challenge, there is a root cause that needs to be addressed (Bolman \& Deal, 2013). Leaders must make that data actionable as it will drive progress and innovation (Cardoza \& Gold, 2018; Gagliardi, 2018b). "Simple things like thinking 
out loud or articulating our assumptions go a long way in opening up reflection and dialogue on our ideas" (Merriam \& Bierema, 2014, p. 277). I am a leader through dialogue. Gill (2010) stated that leaders who work with others through the dialogue process often "try to understand the other person's point of view rather than convince the other person of your point of view. [They] listen to each other, surface underlying assumptions and beliefs, and weave connections among ideas" (p. 87). Bolman and Deal (2013) have given me a variety of lens to see each person's point of view, helping me find the root cause in every problem.

Because of the EdD program, I now look at situations much more holistically. There are "cultural and social differences [that] influence whether and how students perform academically and socially at their institutions" (Dorimé-Williams, 2018, p. 42). Leaders need to help organizations have a more "holistic understanding of student learning" (Dorimé-Williams, 2018, p. 53) in order to better use the data to serve our student population. I believe it is imperative to remember that equitable does not mean equal (Zajda, Majhanovich, \& Rust, 2006), “certainly when that means treating people with widely disparate needs in the same way" (Dorimé-Williams, 2018, p. 43). Datnow and Park (2014) "believe there is value in using data as part of a broader school improvement process and to help create more equitable schools" (p. 7). Comparing data can be a starting point for changing perceptions of equity (Datnow \& Park, 2014). "Equity-minded sensemaking goes beyond examining data and noticing equity gaps in outcomes. It involves interpreting these gaps as a signal that practices aren't working as intended" (Association of American Colleges and Universities, 2018, p. 52). 
While my study focused specifically on rural teacher recruitment and retention, I learned a lot about working within my school, which also falls under the hard-to-staff classification. Learning and leading for change are in a continuous cycle. Gagliardi (2018b) reminds us that learning with data "propels progress and innovation" (p. 1). Knowing this, we understand the importance of making our data actionable (Cardoza \& Gold, 2018). I have found that leading change can be difficult, but according to Datnow and Park (2014), leaders who support people within their organization can use their knowledge to lay the foundation every day.

Staying engaged in the world, reflecting on new experiences, and using new information to help inform decisions is what Creswell (2014) suggests scholarly practitioners do. As a building leader, I will follow Schultz's (2010) advice to keep several things at the core of my practice: values of community, democracy, equity, social justice, and caring. In doing these two things, leaders can better "understand how change occurs, what barriers stand in the way, and how improvement efforts can be sustained" (Datnow \& Park, 2014, pp. 49-50). Lastly, it is vital to remember that reflection is as important as the process and results (Gill, 2010). Without reflecting, it is difficult to learn. 


\section{References}

Ahearn, C., Harmon, H., \& Sanders, J. (2005). How to recruit and retain teachers and other school leaders in hard-to-staff rural and small school districts. Greensboro, NC: Regional Educational Laboratory Southeast.

Allen, N. \& Meyer, J. (1990). The measurement and antecedents of affective, continuance and normative commitment to the organization. Journal of Occupational Psychology, 63, 1-18.

Allen, N. \& Meyer, J. (1996). Affective, continuance, and normative commitment to the organization: An examination of construct validity. Journal of Vocational Behavior, 49, 252-276.

Allen, T., Russell, J., Poteet, M., \& Dobbins, G. (1999). Learning and development factors related to perceptions of job content and hierarchical plateauing. Journal of Organizational Behavior, 20(7), 1113-1137.

Association of American Colleges and Universities. (2018). A vision for equity. Retrieved from https://www.aacu.org/publications/vision-equity

Argyris, C. (1995). Acting science and organizational learning. Journal of Managerial Psychology, 10(6), 20-26. doi: 10.1108/02683949510093849

Armstrong-Stassen, M. (2008). Factors associated with job content plateauing among older workers. Career Development Internation, 37(7), 594-613.

Arthur, W., Jr., Bell, S., Villado, A., \& Doverspike, D. (2006). The use of personorganization fit in employment decision making: An assessment of its criterion related validity. The Journal of Applied Psychology, 91, 786-801. 
Becker, F. (1995). Workplace by design: Mapping the high-performance workscape (1st ed.). San Francisco, CA: Jossey-Bass Publishers.

Beesley, A., Atwill, K., Blair, P., \& Barley, Z. (2010). Strategies for recruitment and retention of secondary teachers in central U.S. rural schools. The Rural Educator, $31(2) 1-9$.

Billsberry, J., Ambrosini, V., Moss-Jones, J., \& Marsh, P. (2005). Some suggestions for mapping organizational members' sense of fit. Journal of Business and Psychology, 19, 555-570.

Bohndick, C., Rosman, T., Kohlmeyer, S., \& Buhl, H. (2018). The interplay between subjective abilities and subjective demands and its relationship with academic success. An application of the person-environment fit theory. Higher Education, 75, 839-854. doi:10.1007/s10734-017-0173-6

Bolman, L. \& Deal, T. (2013). Reframing organizations: Artistry, choice, and leadership. San Francisco, CA: Jossey-Bass.

Borman, G. \& Dowling, M. (2008). Teacher attrition and retention: A meta-analytic and narrative review of research. Review of Educational Research, 78(3), 367-409.

Bowen, D., Ledford, G., Jr., \& Nathan, B. (1991). Hiring for the organization, not the job. The Executive, 5, 35-51.

Bretz, R. D., \& Judge, T. A. (1994). Person-organization fit and the theory of work adjustment: Implications for satisfaction, tenure, and career success. Journal of Vocational Behavior, 44, 32-54. 
Brief, A. (2001). Organizational behavior and the study of affect: Keep your eyes on the organization. Organizational Behavior and Human Decision Processes, 86, 131139.

Brief, A., \& Weiss, H. (2002). Organizational behavior: Affect in the workplace. Annual Review of Psychology, 53, 279 -307.

Bush, T. and Glover, D. (2003) School leadership: Concepts and evidence. National College for School Leadership, 1-42.

Buss, D. (2000). The evolution of happiness. American Psychologist, 55, 15-23.

Missouri is rural? Missourian. Retrieved from https://www.columbiamissourian. com/visuals/graphics/how-much-of-missouri-is-rural/pdf_ba6e98a6-3af4-11e9a75a-5b6864d87feb.html

Cable, D., Gino, F., \& Staats, B. (2013). Breaking them in or eliciting their best? Reframing socialization around newcomers' authentic self-expression. Administrative Science Quarterly, 58, 1-36.

Cable, D., \& Parsons, C. (2001). Socialization tactics and person-organization fit. Personnel Psychology, 54, 1-23.

Cao, C (2019, February 27). How much of Missouri is rural? Missourian. https://www.columbiamissourian.com/visuals/graphics/how-much-of-missouri-isrural/pdf_ba6e98a6-3af4-11e9-a75a-5b6864d87feb.html

Caplan, R. (1987). Person-environment fit theory and organizations: Commensurate dimensions, time perspectives, and mechanism. Journal of Vocational Behavior, $31,248-267$. 
Cardoza, D. \& Gold, J. (2018). Moving from data to action: Changing institutional culture and behavior. In J. S. Gagliardi, A. Parnell, \& J. Carpenter-Hubin (Eds.), The analytics revolution in higher education: Big data, organizational learning, and student success (p. 119-138). Sterling, VA: Stylus.

Carver-Thomas, D. \& Darling-Hammond, L. (2017). Teacher turnover: Why it matters and what we can do about it. Palo Alto, CA: Learning Policy Institute.

Chang, B. (2003). Going beyond career plateau: Using professional plateau to account for work outcomes. The Journal of Management Development, 22(6), 538-551.

Chao, G., O’Leary-Kelly, A., Wolf, S., Klein, H., \& Gardner, P. (1994). Organizational socialization: Its content and consequence. Journal of Applied Psychology, 79, $730-743$.

Chatman, J. (1989). Improving interactional organizational research: A model of personorganization fit. Academy of Management Review, 14, 333-349.

Chatman, J. A. (1991). Matching people and organizations: Selection and socialization in public accounting firms. Administrative Science Quarterly, 36, 459-484.

Creswell, J. (2014). Research design: Qualitative, quantitative, and mixed method approaches. Thousand Oaks, CA: SAGE

Creswell, J. (2016). 30 essential skills for the qualitative researcher. Thousand Oaks, CA: SAGE

Cummings, T. \& Cooper, C. (1979). Cybernetic framework for studying occupational stress, Human Relations, 32, 395-418.

Daniels, E., Hondeghem, A., \& Dochy, F. (2019). A review on leadership and leadership development in educational settings. Educational Research Review, 27, 110-125. 
Datnow, A., \& Park, V. (2014). Data-Driven Leadership. San Francisco, CA: JosseyBass.

Dawis, R. \& Lofquist, L. (1984). A psychological theory of work adjustment: An individual-differences model and its applications. Minneapolis, MN: University of Minnesota Press.

Desimone, L., Porter, A., Garet, M., Yoon, S., \& Birman, B. (2002). Effects of professional development on teachers' instruction: Results from a three-year longitudinal study, Educational Evaluation and Policy Analysis, 24(2), 81-112.

de Vos, A., Buyens, D., \& Schalk, R. (2005). Making sense of the new employment relationship: Psychological contract-related information seeking and the role of work values and locus of control. International Journal of Selection and Assessment, 13, 41-52.

Dorimé-Williams, M. (2018). Developing socially just practices and policies in assessment. New Directions in Institutional Research, 177, 41-56. Retrieved from: https://onlinelibrary-wileycom.proxy.mul.missouri.edu/ doi/10.1002/ir.20255

Eberhard, J., Reinhardt-Mondragon, P., \& Stottlemyer, B. (2000). Strategies for new teacher retention: Creating a climate of authentic professional development for teachers with three or less years of experience. Corpus Christi: TX: A\&M University, South Texas Research and Development Center. 
Edwards, J., Caplan, R., \& van Harrison, R. (1998). Person-environment fit theory. Conceptual foundations, empirical evidence and directions for future research. In C. Cooper (Ed.), Theories of organizational stress (pp. 28-67). Oxford, UK: Oxford University Press.

Edwards, J. \& Cooper, C. (1990). The person-environment fit approach to stress: Recurring problems and some suggested solutions. Journal of Organizational Behavior, 11, 293-307.

Edwards, J. \& Shipp, A. (2007). The relationship between person-environment fit and outcomes: An integrative theoretical framework. In C. Ostroff \& T. Judge (Eds.), Perspectives on organizational fit (pp. 209-258). New York, NY: Erlbaum.

Edwards, J. \& Van Harrison, R. (1993). Job demands and worker health: Threedimensional reexamination of the relationship between person-environment fit and strain. Journal of Applied Psychology, 78(4), 628-648.

Elfers, A. M., \& Plecki, M. L. (2006). Examining teacher retention and mobility in small and rural districts in Washington state. Seattle: University of Washington College of Education.

Ellis, C., Skidmore, S., \& Combs, J. (2017). The hiring process matters: The role of person-job and person-organization fit in teacher satisfaction. Educational Administration Quarterly, 53(3), 448-474. doi:10.1177/0013161X16687007

Ettling, D. (2012). Educator as change agent: Ethics of transformative learning. In E. Taylor \& P. Cranton (Eds.), The handbook of transformative learning: Theory, research, and practice (pp. 536-551). San Francisco, CA: Jossey-Bass. 
Etzel, J. \& Nagy, G. (2016). Students' perceptions of person-environment fit. Do fit perceptions predict academic success beyond personality traits? Journal of Career Assessment, 24(2), 270-288. doi:10.1177/1069072715580325

Feng, L. (2017) Stemming the tide: Are public school districts keeping the best and brightest teachers? Retrieved from https://www.brookings.edu/blog/browncenter-chalkboard/2017/06/01/stemming-the-tide-are-public-school-districtskeeping-the-best-and-brightest-teachers/

Follmer, E., Talbot, D., Kristof-Brown, A., Astrove, S., \& Billsberry, J. (2018). Resolution, relief, and resignation: A qualitative study of responses to misfit at work. Academy of Management Journal, 61(2), 440-465.

French, J., Jr., Rodgers, W., \& Cobb, S. (1974). Adjustment as person-environment fit. In G. Coelho, D. Hamburg, \& J. Adams (Eds.), Coping and adaptation. New York, NY: Basic Books.

Gagliardi, J. S. (2018a). Unpacking the messiness of harnessing the analytics revolution. In J. S. Gagliardi, A. Parnell, \& J. Carpenter-Hubin (Eds.), The analytics revolution in higher education: Big data, organizational learning, and student success (p. 189-200). Sterling, VA: Stylus.

Gagliardi, J. (2018b). The analytics revolution in higher education. In J. Gagliardi, A. Parnell, \& J. Carpenter-Hubin (Eds.), The analytics revolution in higher education: Big data, organizational learning, and student success (pp. 1-14). Sterling, VA: Stylus Publishing, LLC. 
Georg, W. (2009) Individual and institutional factors in the tendency to drop out of higher education: A multilevel analysis using data from the Konstanz Student Survey. Studies in Higher Education, 34(6), 647-661. doi:10.1080/03075070802592730

Gill, S. J. (2010). Developing a learning culture in nonprofit organizations. Los Angeles, CA: Sage.

Grove, S. D. (2008). A comparison of elementary, middle, and high school principals' teacher selection practices and perceptions of teacher effectiveness, Educational Administration Quarterly, 53(3).

Guan, Y., Deng, H., Sun, J., Wang, Y., Cai, Z., Ye, L., Gu, R., Wang, Y., Zhang, S., \& Li, Y. (2013). Career adaptability, job search self-efficacy and outcomes: A threewave investigation among Chinese university graduates. Journal of Vocational Behavior, 83(3), 561-570.

Harold, C., Oh, I., Holtz, B., Han, S., \& Giacalone, R. (2016). Fit and frustration as drivers of targeted counterproductive work behaviors. The Journal of Applied Psychology, 101, 1513-1535.

Harrison, R. (1978). Person-environment fit and job stress. In C. L. Cooper \& R. Payne (Eds.), Stress at work (pp. 175-205). New York, NY: Wiley.

Harrison, D. (2007). Pitching fits in applied psychological research: Making fit methods fit theory. In C. Ostroff \& T. Judge (Eds.), Perspectives on organizational fit, 389-416. Chicago, IL: Lawrence Erlbaum Associates. 
Heibutzki, R. (2019). The organizational structure of a school district. The Classroom. Retrieved from https://www.theclassroom.com/organizational-structure-schooldistrict-6618604.html

Heifetz R. \& Laurie D. (2011). The work of leadership. In P. Drucker, Harvard business review: On leadership (pp. 57-78). Boston, MA: Harvard Business School Publishing Cooperation.

Heise, E., Westermann, R., Spies, K., \& Stephan, H. (1997). The fit of abilities and needs of students of different subjects with requirements and supplies as determinants of study satisfaction. Educational psychology in education and organization. Symposium of Educational Psychology Dortmund (2nd ed.). Essen, Germany: Die blaue Eule.

Hoffman, B. \& Woehr, D. (2006). A quantitative review of the relationship between person-organization fit and behavioral outcomes. Journal of Vocational Behavior, 68, 389-399.

Hofstetter, H., \& Choen, A. (2014). The mediating role of job content plateau on the relationship between work experience characteristics and early retirement and turnover intentions. Personnel Review, 43(3), 350-376.

Holland, J. (1997). Making vocational choices: A theory of vocational personalities and work environments. Englewood Cliffs, NJ: Prentice Hall.

Hong, J. (2010). Pre-service and beginning teachers' professional identity and its relation to dropping out of the profession. Teaching and Teacher Education, 26(8), 15301543. 
Huling, L. (1998). Texas board for educator certification panel on novice teacher induction support system: Final report. Austin, TX: Texas State Board for Educator Certification.

Huysman, J. (2008). Rural teacher satisfaction: An analysis of beliefs and attitudes of rural teachers' job satisfaction. The Rural Educator, 29(2), 31-38.

Ingersoll, R. M. (2001). Teacher turnover and teacher shortages: An organizational analysis. American Educational Research Journal, 55(3), 499-534.

Jansen, K. J., \& Kristof-Brown, A. L. 2006. Toward a multi-dimensional theory of person-environment fit. Journal of Managerial Issues, 193-212.

Jiang, Z. (2016). The relationship between career adaptability and job content plateau: The mediating roles of fit perceptions. Journal of Vocational Behavior, 95-96, 110.

Jimerson, L. (2003). The competitive disadvantage: Teacher compensation in rural America. Washington, DC: The Rural School and Community Trust Policy Brief.

Johnson, A. (2018). The trouble with trouble. Privilege, power and difference (3rd ed.). New York, NY: McGraw-Hill.

Johnson, S., Birkeland, S., Kardos, S., Kauffman, D., Liu, E., \& Peske, H. (2001). Retaining the next generation of teachers: The importance of school-based support. Harvard Education Letter, 17(4).

Kaden, U., Patterson, P., Healy, J. \& Adams, B (2016). Stemming the revolving door: Teacher retention and attrition in Arctic Alaska schools. Global Education Review, 3(1). 129-147. 
Karasek, R., Jr. (1979). Job demands, job decision latitude, and mental strain: Implications for job redesign. Administrative Science Quarterly, 24, 285-308.

Katz, D. \& Kahn, R. (1978). The social psychology of organizations. New York, NY: Wiley.

Kim, I. \& Loadman, W. (1994). Predicting teacher job satisfaction. (ERIC Document Reproduction Service, no. ED383707).

Kotter, J. (2011). What leaders really do. In Harvard business review's 10 must reads: On leadership (p. 37-55). Boston, MA: Harvard Business Review Press. (Reprinted from May 1990) Kristof, A. (1996). Person-organization fit: An integrative review of its conceptualizations, measurement, and implications. Personnel Psychology, 49, 1-49. Retrieved from http://dx.doi.org/10.1111/j.17446570.1996.tb01790.x

Kristof, A. (1996). Person-organization fit: An integrative review of its conceptualizations, measurement and implications. Personnel Psychology, 49(1), $1-49$.

Kristof-Brown, A. \& Guay, R. (2011). Person-environment fit. In S. Zedeck (Ed.), APA handbook of industrial and organizational psychology, 3-50. Washington, D.C.: American Psychological Association.

Kristof-Brown, A., Zimmersonman, R., \& Johnson, E. (2005). Consequences of individuals' fit at work: A meta-analysis of person-job, person-organization, person-group, and person-supervisor fit. Personnel Psychology, 58(2), 281-342.

Larsen, R. (2000). Toward a science of mood regulation. Psychological Inquiry, 11, 129 $-141$. 
Lemke, J. (1994). Teacher induction in rural and small districts. In D. Montgomery (Ed.), Rural partnerships: Working together. Proceedings of the Annual National Conference of the American council on Rural Education. Austin, TX: (ERIC Document Reproduction Service, no. ED369589).

Lencioni, P. (2002). The five dysfunctions of a team: A leadership fable. San Francisco, CA: Jossey-Bass.

Levi, D. (2017). Group dynamics for teams (5th ed.). Thousand Oaks, CA: Sage.

Li, Y., Yao, X., Chen, K., \& Wang, Y. (2013). Different fit perceptions in an academic environment: Attitudinal and behavioral outcomes. Journal of Career Assessment, 21(2), 163-174. doi:10.1177/1069072712466713

Liden, R., Wayne, S., Zhao, H., \& Henderson, D. (2008). Servant leadership: Development of a multidimensional measure and multi-level assessment. The Leadership Quarterly, 19, 161-177.

Locke, E. (1984). Job satisfaction. In M. Gruneberg \& T. Wall (Eds.), Social psychology and organizational behavior (pp. 93-117). Chichester, UK: Wiley.

London, R., Sanchez, M., \& Castrechini, S. (2016). The Dynamics of Chronic Absence and Student Achievement. Education Policy Analysis Archives, 24(112), 3-27.

Luekens, M., Lyter, D., \& Fox, E. (2004). Teacher Attrition and Mobility: Results from the Teacher Follow-up Survey, 2000-01 (No. NCES 2004-301). Washington, DC: U.S. Government Printing Office.

Malloy, W. \& Allen, T. (2007) Teacher retention in a teacher resiliency-building rural school. The Rural Educator, 28(2), 19-27. 
Mandinach, E. (2012). A perfect time for data use: Using data-driven decision making to inform practice. Educational Psychologist, 47(2), 71-85. doi:

$10.1080 / 00461520.2012 .667064$

Maranto, R. \& Shuls, J. (2012). How do we get them on the farm? Efforts to improve rural teacher recruitment and retention in Arkansas. The Rural Educator, 34(1), 32-40.

Markham, A. \& Buchanan, E. (2012). Ethical decision-making and internet research: Recommendations from the AoIR ethics working committee (Version 2.0). Retrieved from: https://aoir.org/ethics/

Materson, S. \& Stamper, C. (2003). Perceived organizational membership: An aggregate framework representing the employee-organization relationship. Journal of Organizational Behavior, 24, 473-490.

McCleese, C. \& Eby, L. (2006). Reactions to job content plateaus: Examining role ambiguity and hierarchical plateaus as moderators. The Career Development Quarterly, 55(1), 64-76.

McClure, C. \& Reeves, C. (2004). Rural teacher recruitment and retention review of the research and practice literature. Appalachia Educational Laboratory, 1-23.

McGrath, J. (1976). Stress and behavior in organization. In M. D. Dunnete (Eds), Handbook of industrial and organizational psychology (pp. 1351-1395). Chicago, IL: Rand McNally.

Merriam, S. \& Bierema, L. (2014). Adult learning: Linking theory and practice. San Francisco, CA: Jossey-Bass. 
Merriam, S. \& Tisdell, E. (2016). Qualitative research: A guide to design and implementation (4th ed.). San Francisco, CA: Jossey-Bass.

Missouri Association of Rural Education (2019a). Member benefits. Retrieved from https://www.moare.com/vnews/display.v/SEC/About\%20MARE\%7CReasons\%2 0for\%20joining

Missouri Association of Rural Education (2019b). Purpose. Retrieved from https://www.moare.com/vnews/display.v/SEC/about\%20MARE\%7CPurpose Missouri Census Data Center (2019). Ten Things to Know About Urban Vs. Rural. Retrieved from http://mcdc.missouri.edu/help/ten-things/urban-rural.html Missouri Department of Elementary and Secondary Education (2019a). About the state board. Retrieved from https://dese.mo.gov/state-board-education/about-stateboard

Missouri Department of Elementary and Secondary Education (2019b). Facts about the Department of Elementary and Secondary Education. Retrieved from https://dese.mo.gov/state-board-education/overview

Missouri Department of Elementary and Secondary Education (2019c). MSIP 5: Preparing every child for success in school and in life. Retrieved from https://dese.mo.gov/quality-schools/mo-school-improvement-program/msip-5 Missouri Department of Elementary and Secondary Education (2019d). Comprehensive guide: MSIP 5. Retrieved from https://dese.mo.gov/sites/default/files/MSIP-52018-Comprehensive-Guide\%20(3).pdf

Missouri Department of Elementary and Secondary Education (2019e). MAP information for parents. Retrieved from https://dese.mo.gov/map-information-parents 
Missouri Department of Elementary and Secondary Education (2019f). School directory. Retrieved from https://dese.mo.gov/school-directory

Mitchell, T., Holtom, B., Lee, T., Sablynski, C., \& Erez, M. (2001). Why people stay: Using job embeddedness to predict voluntary turnover. Academy of Management Journal, 44, 1102-1122.

Mitchell, T. \& Lee, T. (2001). The unfolding model of voluntary turnover and job embeddedness: Foundations for a comprehensive theory of attachment. Research in Organizational Behavior, 223, 189-248.

Muchinsky, P. \& Monahan, C. (1987). What is person-environment congruence? Supplementary versus complementary models of fit. Journal of Vocational Behavior, 31, 268-277.

Mulki, J., Jaramillo, F., \& Locander, W. (2006). Emotional exhaustion and organizational deviance: Can the right job and a leader's style make a difference? Journal of Business Research, 59, 1222-1230.

Mulvahill, E. (2018) Why teachers quit. Retrieved from https://www.weareteachers. com/why-teachers-quit/

Murray, H. (1938). Explorations in personality. New York, NY: Oxford University Press. The National Center for Education Statistics (1995). Which types of schools have the highest teacher turnover? Retrieved from https://nces.ed.gov/pubs95/web/ 95778.asp

The National Center for Educational Statistics. (2008). Data Analysis System Online Application. Retrieved from http://nces.ed.gov/dasolv2/tables/showPrintTable.asp 
The National Commission on Teaching and America's Future. (2007). The high cost of teacher turnover. Retrieved from http://www.nctaf.org/wp-content/uploads /2012/01/NCTAF-Cost-of-Teacher-Turnover-2007-policy-brief.pdf

National Rural Education Association. (2019a). Welcome to NREA. Retrieved from https://www.nrea.net/Home

National Rural Education Association. (2019b). The rural educator. Retrieved from https://www.nrea.net/Home

Naus, F., Van Iterson, A., \& Roe, R. (2007). Value incongruence, job autonomy, and organization-based self-esteem: A self-based perspective on organizational cynicism. European Journal of Work and Organizational Psychology, 16(2), 195 219.

Nordic Council of Ministers. (2010). Arctic social indicators: A follow up to the Arctic Human Development Report. Copenhagen, DK: Author.

Northouse, P. (2016). Leadership theory and practice (7th ed.). Thousand Oaks, CA: Sage.

Oh, I., Guay, R., Kim, K., Harold, C., Lee, J., Heo, C., \& Shin, K. (2014). Fit happens globally: A meta-analytic comparison of the relationships of person-environment fit dimensions with work attitudes and performance across East Asia, Europe, and North America. Personnel Psychology, 67, 99-152.

Parnell, A. (2018). Data analytics for student success: Elaborate profusion of institutional research into student affairs. In J. S. Gagliardi, A. Parnell, \& J. Carpenter-Hubin (Eds.), The analytics revolution in higher education: Big data, organizational learning, and student success (p. 43-54). Sterling, VA: Stylus. 
Perrachione, B., Rosser, V., \& Petersen, G. (2008). Why do they stay? Elementary teachers' perceptions of job satisfaction and retention. The Professional Educator, $32(2), 25-41$.

Podolsky, A., Kini, T., Bishop, J., \& Darling-Hammond, L. (2016). Solving the teacher shortage: How to attract and retain excellent educators. Palo Alto, CA: Learning Policy Institute.

Pogodzinski, B., Youngs, P., \& Frank, K. (2013). Collegial climate and novice teachers' intent to remain teaching. American Journal of Education, 120(1), 27-54.

Reichheld, F. (1996). The loyalty effect: The hidden force behind growth, profits, and lasting value. Boston, MA: Harvard Business School Press.

Reis, S. \& McCoach, D. (2000). The underachievement of gifted students: What do we know and where do we go? The Gifted Child Quarterly, 44(3), 152-170. doi:10.1177/001698620004400302

Ronfeldt, M., Loeb, S., \& Wyckoff, J. (2013). How teacher turnover harms student achievement. American Educational Research Journal, 50(1), 4-36. doi: 10.3102/ 0002831212463813

The Rural Educator (2019a). Information for authors. Retrieved from https://journals.library.msstate.edu/ruraled/information/authors

The Rural Educator (2019b). Submissions. Retrieved from https://journals.library.msstate.edu/ruraled/information/authors Sargent, B. (2003). Finding good teachers and keeping them. Educational Leadership, $60(8), 44-47$. 
Savickas, M. (1997). Career adaptability: An integrative construct for life-span, life-space theory. The Career Development Quarterly, 45(3), 247-259.

Savickas, M. (2013). Career construction theory and practice. In S. D. Brown, \& R. W. Lent (Eds), Career development and counseling: Putting theory and research to work (pp. 147-183) (2nd ed). Hobken, NJ: John Wiley \& Sons.

Savickas, M. \& Porfeli, E. (2012). Career Adapt-Abilities Scale: Construction, reliability, and measurement equivalence across 13 countries. Journal of Vocational Behavior, 80(3), 661-673. http://dx.doi.org/10.1016/j.jvb.2012.01.011

Schein, E., (2005) The bases of social power. In D. Tatum \& D. Blush (Eds.), Classics of organization theory (pp. 360-367). Belmont, CA. (Reprinted from Organizational Culture and Leadership, 2nd ed., pp. 3-15, by E. Schein, 1993, San Francisco, CA: Jossey-Bass)

Schneider, B. (1987). The people make the place. Personnel Psychology, 40, 437-453.

Schneider, B., Goldstein, H., \& Smith, D. (1995). The ASA framework: An update. Personnel Psychology, 48, 747-773. Retrieved from http://dx.doi.org/10.1111/ j.1744-6570.1995.tb01780.x

Schultz, J. (2010). The scholar-practitioner: A philosophy of leadership. ScholarPractitioner Quarterly, 4(1), 52-64.

Seidman, I. (2013). Interviewing as qualitative research: A guide for researchers in education \& the social sciences (4th ed.). New York, NY: Teachers College Press. 
Shen, J., \& Cooley, V. (2008). Critical issues in using data for decision-making. International Journal of Leadership in Education, 11(3), 319-329. doi: $10.1080 / 13603120701721839$

Shen, J., Leslie, J., Spybrook, J., \& Ma, Z. (2012). Are principal background and school processes related to teacher job satisfaction? A multilevel study using schools and staffing survey 2003-04. American Educational Research Journal, 49(2), 200230.

Shipp, A. \& Jansen, K. 2011. Reinterpreting time in fit theory: Crafting and recrafting narratives of fit in media res. Academy of Management Review, 36, 76-101.

Skaalvik, E. \& Skaalvik, S. (2011). Teacher job satisfaction and motivation to leave the teaching profession: Relations with school context, feeling of belonging, and emotional exhaustion. Teaching and Teacher Education, 27(6): 1029-1038.

Southeast Center for Teaching Quality. (2004). Unfilled promise: Ensuring high quality teachers for our nation's students. No Child Left Behind: A status report from southeastern schools. Chapel Hill, NC: Southeast Center for Teaching Quality. Retrieved from www.teachingquality.org

Strizek, G., Pittsonberger, J., Riordan, K., Lyter, D., \& Orlofsky, G. (2006). Characteristics of Schools, Districts, Teachers, Principals, and School Libraries in the United States: 2003-04 Schools and Staffing Survey (No. NCES 2006-313 Revised). Washington, DC: U.S. Government Printing Office.

TALIS (2008). The experience of new teachers. Results from TALIS 2008. Paris, France: OECD. 
Tierney, W (2012). Creativity and organizational culture. In M. Bastedo (Ed.), The organization of higher education managing colleges for a new era (pp. 160-180). Baltimore, MD: The Johns Hopkins University Press.

Trevino, L., Hartman, L., \& Brown, M. (2000). Moral person and moral manager: How executives develop a reputation for ethical leadership. California Management Review, 42(4), 128-142.

Ulferts, J. (2016). Brief summary of teacher recruitment and retention in the smallest Illinois rural schools. The Rural Educator, 37(1), 14-24.

Van Beurden, J., Can Veldhoven, M., Nijendijk, K., \& Van De Voorde, K. (2017). Teachers' remaining career opportunities: The role of value fit and school climate. Teaching and Teacher Education, 68, 143-150.

van Vianen, A. (2018). Person-environment fit: A review of its basic tenets. The Annual Review of Organizational Psychology and Organizational Behavior, 5, 75-101.

Vekeman, E., Devos, G., Valcke, M., \& Rosseel, Y. (2018). Principals' configuration of a bundle of human resource practices. Does it make a difference for the relationship between teachers' fit, job satisfaction and intention to move to another school? Educational Management Administration \& Leadership, 46(5), 820-840.

Vermunt, J., Richardson, J., Donche, V., \& Gijbels, D. (2014). Students' learning patterns in higher education. Dimensions, measurement and change. In D. Gijbels, V. Donche, J. Richardson, \& J. Vermunt (Eds.), Learning patterns in higher education. Dimensions and research perspectives (pp. 295-310). London, UK: Routledge. 
Vogel, R., Rodell, J., \& Lynch, J. (2016). Engaged and productive misfits: How job crafting and leisure activity mitigate the negative effects of value incongruence. Academy of Management Journal, 59, 1561-1584.

Waldman, D., \& Spangler, W. (1989). Putting together the pieces: A closer look at the determinants of job performance. Human Performance, 2(1), 29-59. doi:10.1207/s15327043hup0201_2.

Watson, D. \& Tellegen, A. (1985). Toward a consensual structure of mood. Psychological Bulletin, 98, 219 -235.

Wheeler, A., Gallagher, V., Brouer, R., \& Sablynski, C. (2007). When personorganization (mis)fit and (dis)satisfaction lead to turnover: The moderating role of perceived job mobility. Journal of Managerial Psychology, 22, 203-219.

Youngs, P., Pogodzinski, B., Grogan, E., \& Perrone, F. (2015). Person-organization fit and research on instruction. Educational Researcher, 44(1), 37-45.

Yu, K. (2009). Affective influences in person-environment fit theory: Exploring the role of affect as both cause and outcome of p-e fit. Journal of Applied Psychology, 94(5), 1210-1226. doi:10.1037/a0016403

Yu, K. (2013). A motivational model of person-environment fit: Psychological motives as drivers of change. In A. L. Kristof-Brown \& J. Billsberry (Eds.). Organizational fit: Key issues and new directions (pp. 19-49). Chichester, UK: Wiley-Blackwell.

Zajda, J., Majhanovich, S., \& Rust, V. (2006). Introduction: Education and social justice. Review of Education, 52, 9-22. 
Zhang, Y. (2008). Some perspectives from rural school districts on the No Child Left Behind Act. Washington, DC: Center on Education Policy. Retrieved from http://files.eric.ed.gov/fulltext/ED503795.pdf 


\section{Appendix A}

\section{Missouri Maps}
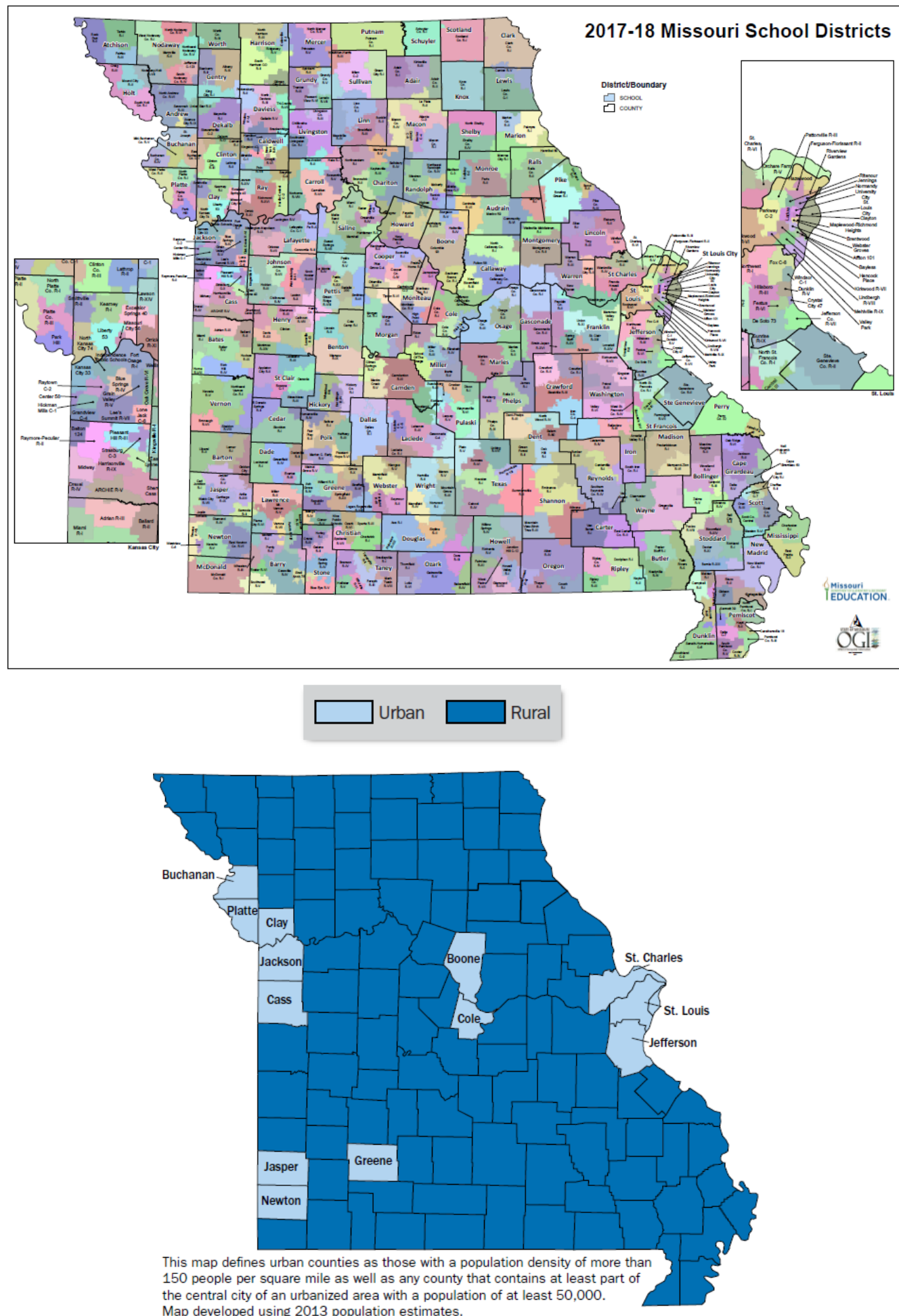
Appendix B

\section{Email Requesting District Participation in Study}

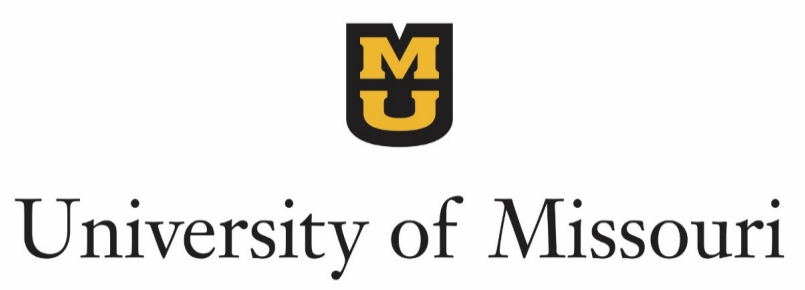

Good Afternoon,

My name is Amanda Minear, and I am a doctoral candidate with the University of Missouri. I requesting to use your school district in a research study I am conducting.

The purpose of this study is to understand what aspect of the impact person-environment fit theory has on recruitment and retention in a rural school district ultimately helping hiring practices of school administrators.

If you will allow me to use your school district in my research study, teachers and administrators will be asked to participate in an interview which will be kept under one hour. All the teachers selected will be based on recommendations of the district administration. The interview will focus on their success of working in your rural school district. I will also offer teachers an opportunity to participate in an additional focus group.

All of the information I collect will be confidential. Care will be taken in regard to your responses to protect your anonymity. Participation in this study is completely voluntary, and there are no consequences should you choose not to participate.

Your participation in this study will be greatly appreciated! You can indicate your willingness to participate by replying to this email by (date noted here).

Thank you so much, Amanda Minear 
Appendix C

\section{Email Requesting Individual Participation in Study}

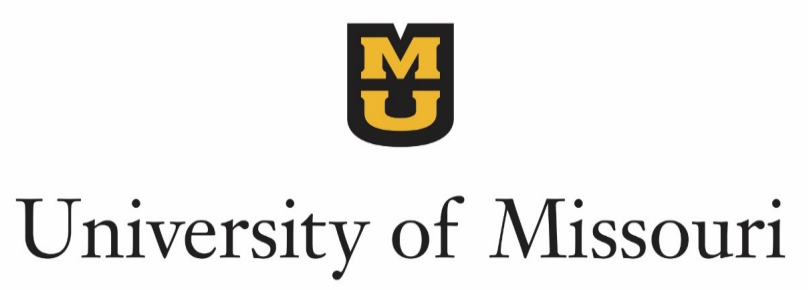

Good Afternoon,

My name is Amanda Minear, and I am a doctoral candidate with the University of Missouri. I am inviting you to participate in a research study I am conducting.

The purpose of this study is to understand what aspect of the impact person-environment fit theory has on recruitment and retention in a rural school district ultimately helping hiring practices of school administrators.

If you agree to participate in this study, you will be asked to participate in one interview which will be kept under one hour. The interview will focus on your experiences with recruiting and retaining highly effective teachers in your rural school district. All of the information I collect will be confidential. Care will be taken in regard to your responses to protect your anonymity.

Participation in this study is completely voluntary, and there are no consequences should you choose not to participate.

Your participation in this study will be greatly appreciated! You can indicate your willingness to participate by replying to this email by (date noted here).

Thank you so much, Amanda Minear 
Appendix D

Consent Form to Participate in Study

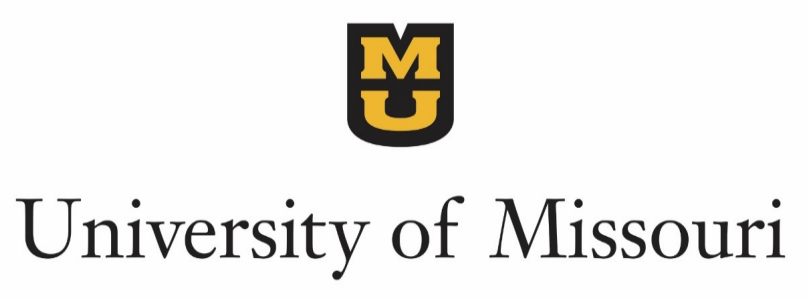

CONSENT FORM TO PARTICIPATE IN A RESEARCH STUDY

\author{
Researcher's Name: Amanda Minear \\ Project Number: 2021603 \\ Project Title: The Impact Person-Environment Fit Theory has on Teacher Recruitment \\ and Retention
}

\title{
STUDY SUMMARY:
}

You are being asked to participate in a research study. This research is being conducted to understand what aspect of the impact person-environment fit theory has on recruitment and retention in a rural school district. You have the right to know what you will be asked to do so that you can decide whether or not you would like to participate. Your participation is voluntary. If you decide not to participate, you will not be penalized in any way. You can also decide to stop at any time without penalty. If you do not wish to answer any of the questions, you may simply not answer them.

\section{PURPOSE OF THE STUDY:}

The purpose of this study is to understand what aspect of the impact person-environment fit theory has on recruitment and retention in a rural school district ultimately helping hiring practices of school administrators.

\section{REQUEST FOR PARTICIPATION:}

I am inviting you to participate in a study on teacher recruitment and retention. You are being asked to complete an interview. All of the information I collect will be kept confidential. Audio recordings will be destroyed upon completion of this study.

\section{QUESTIONS, CONCERNS, OR COMPLAINTS:}

Please contact Dr. Sandy Hutchinson, dissertation chair, at hutchinson@ucmo.edu, if you have questions about the research. Additionally, you may ask questions, voice concerns, or register complaints to the researcher, Amanda Minear, at alf8tc@mail.missouri.edu. If you want to talk privately about your rights or any issues related to your participation in this study, you can contact University of Missouri Research Participant Advocacy by calling (888) 280-5002, a free call, or emailing MUResearchRPA@missouri.edu. 


\section{Appendix E}

\section{Interview Protocol for Teachers}

1. Tell me a little bit about your career path. How did you find your way to this school? How did you get here? How did you get to this place?

2. Could you tell me about the induction process? What did your mentoring program look like?

3. Tell me about your school. What goes on here? How does it operate? What are the duties and expectations of your job? What are the school's goals?

4. Let's talk about your school community. What are your students like? What about parents? Are you involved with the school board? Community involvement?

5. How many administrators have you worked for at this school? Tell me about your current administrator. What are your interactions like? Do you work closely with them? If so, can you give me an example?

6. Do you collaborate with other staff members? If so, with whom? Talk about who you work with. How do you do what you do? How do you plan your curriculum?

7. Tell me about your hiring process. Can you describe it to me? What was your interview like? How did you decide that this is where you wanted to be?

8. What are some things that attracted you to this school? What did you like? What did you see as positives? Was there anything that concerned you when you began working here? How do you feel about those things now?

9. How would you define teacher satisfaction? Are you satisfied here? Why?

10. How would you describe yourself? Whether it comes to your personality or your teaching style, what words or phrases would you use?

11. How would you define teacher success?

12. Why do you think you've been successful at this school? Why have you been here for (number) amount of years? Why have you stayed? Why has this been a good fit for you? 


\section{Appendix F}

\section{Interview Protocol for Administrators}

1. What does your role at this school look like? What is your role in working with your teachers?

2. Tell me about your school. How does it operate on a daily basis? What are the school's goals? What are the students like? What about parents? How involved are you with teachers?

3. Are the teachers' part of a team? If so, how does it function? If not, what ways do teachers collaborate with colleagues? What do those opportunities look like?

4. What do you do to recruit people to your school?

5. What does the hiring process look like here? Is there something in particular that you look for during the hiring process that lets you know that this candidate will be successful? How effective do you think you are in hiring people who are going to stay long term?

6. How do you support your new teachers?

7. Talk to me about professional development. What does it look like at this school? Do you select the topic or do teachers interest drive it?

8. How would you define teacher success? You've recommended some teachers to me, what do you think specifically makes them successful? What has made them stay long term?

9. What are some of the strengths of the successful teachers you recommended? What characteristics would you say describe them?

10. What do you think is most important to your teachers?

11. Why do you think people stay here long term? 
Appendix G

\section{Research Questions and Corresponding Interview Questions}

(1) What elements of person-environment fit theory appear to be important to retention of teachers in rural public schools?

\section{$\underline{\text { Teacher }}$}

- Tell me about your school. What goes on here? How does it operate? What are the duties and expectations of your job? What are the school's goals?

- Let's talk about your school community. What are your students like? What about parents? Are you involved with the school board? Community involvement?

- How many administrators have you worked for at this school? Tell me about your current administrator. What are your interactions like? Do you work closely with them? If so, can you give me an example?

- Do you collaborate with other staff members? If so, with whom? Talk about who you work with. How do you do what you do? How do you plan your curriculum?

\section{$\underline{\text { Administrator }}$}

- What does your role at this school look like? What is your role in working with your teachers?

- Tell me about your school. How does it operate on a daily basis? What are the school's goals? What are the students like? What about parents? How involved are you with teachers?

- Are the teachers' part of a team? If so, how does it function? If not, what ways do teachers collaborate with colleagues? What do those opportunities look like?

(2) What factors lead administrators to the hiring of a teacher who has successfully worked long-term in a rural school district?

$\underline{\text { Teacher }}$

- Tell me about your hiring process. Can you describe it to me? What was your interview like? How did you decide that this is where you wanted to be? 
- What are some things that attracted you to this school? What did you like? What did you see as positives? Was there anything that concerned you when you began working here? How do you feel about those things now?

\section{$\underline{\text { Administrator }}$}

- What do you do to recruit people to your school?

- What does the hiring process look like here? Is there something in particular that you look for during the hiring process that lets you know that this candidate will be successful? How effective do you think you are in hiring people who are going to stay long term?

(3) Why do those teachers persist in rural public schools?

Teacher

- How would you define teacher satisfaction? Are you satisfied here? Why?

- How would you describe yourself? Whether it comes to your personality or your teaching style, what words or phrases would you use?

- How would you define teacher success?

- Why do you think you've been successful at this school? Why have you been here for (number) amount of years? Why have you stayed? Why has this been a good fit for you?

\section{$\underline{\text { Administrator }}$}

- How do you support your new teachers?

- Talk to me about professional development. What does it look like at this school? Do you select the topic or do teachers interest drive it?

- How would you define teacher success? You've recommended some teachers to me, what do you think specifically makes them successful? What has made them stay long term?

- What are some of the strengths of the successful teachers you recommended? What characteristics would you say describe them?

- What do you think is most important to your teachers?

- Why do you think people stay here long term? 
Appendix $\mathrm{H}$

\section{Transcript Data Organized by Interview Question Topics}

\section{Characteristics of Successful Teachers}

When teachers were asked to describe themselves, many of them mentioned that they are flexible. Nina and James said that they try to be laid back with their students. Julia also said that she likes to have fun. "[I'm] energetic, but also want people to pull their weight." She prefers to be a team player with her coworkers. Many teachers mentioned they are organized. Mya said she has taken on many extra roles this year and that she's heard many people tell her that she is organized. She also likes to stay positive. Cara also said that she is a very positive person. Elena is outgoing. She said that she jumps "in the middle of whatever needs done" at school. Jacob "loves putting humor into everything."

Another trait that was mentioned on more than one occasion was organized. Jana said that she is a list maker. She likes "knowing what I need to accomplish each day." Melissa said that she is "very goal oriented. I am very driven by goals, but also the progress in meeting the goal.” Melissa and Emma said that they are structured. Emma joked that she is a "casual perfectionist." She was not the only one. Nora said she "sets high expectations for my kids. I feel like if you set the expectation, [students] will rise to them." Elena always has high expectations. She said that she puts "a lot of the learning on their plate" instead of hers.

Several teachers said that they use their skills to get to know his students better. James said that he is conversational and conducts his class that way. Jacob does the same thing. He teaches government and uses his curriculum to get to know kids on a personal 
level. Caleb said that he cares for his students. "I care sometimes too much." He continued on to talk about how that impacts his students. He said, "believe it or not, those little rascals know when you care." Elena said she "doesn't sugarcoat stuff" and that she thinks her kids appreciate that.

Nicole "doesn't like things to get stale." She said she is constantly reaching out for new ideas to incorporate into her classroom. Mya also said that she likes to be innovative. James agreed that he is flexible and willing to try new things. All administrators also agreed that their most successful teachers look for opportunities to grow in their field. Joel said that "they are constantly looking for ways to improve their craft." Natalie agreed that her teachers have an unmatched "drive to improve...they have a willingness and ability to want to learn new things. They don't want to be stagnant and realize that things are changing. They are able to embrace that and still teach at a high level." Ultimately, all the successful teachers interviewed had a strong passion for their profession.

When administrators were asked to describe the teachers they recommended to be interviewed, they had all positive remarks to make. Natalie said her teachers are always going above and beyond for their students. "They work the extra time with not expecting anything extra." Ethan and Joel agreed that compassion played a big part in their teachers' success. Joel continued on to say that his teachers "connect well with our students. They connect well with our community." All the successful teachers had good rapport with their school-community as a whole. Joel also mentioned that his best teachers are able to effectively communicate with others. Mark agreed. He said the most 
important skill his successful teachers' have in common are their ability to communicate with anybody. "Those individuals just have a knack for it," he said.

\section{Path to Rural Schools}

Teachers were asked what their path to their rural school was like. Many had a connection to a rural community. Nicole said that she grew up only school three miles from the school she currently works at. This is not uncommon. Cara went to the school she now teaches at. She said that she always knew that she wanted to teach in Coalsville while growing up. Nina moved to New Falls in middle school. She said her situation "was kind of weird." She was a cadet teacher in high school and the principal kept tabs on her through college. The principal encouraged Nina to apply for the University of Missouri's Fellows Program so that she could come back to work at New Falls.

Farming is something that brings many students back to the rural area they grew up in. Emma said that she took over her family farm after college, so moving to a different area was not an option. James said the same thing about moving back to the area he was raised in. He went to school at Joanstown and then came back to be the agriculture teacher. Spouses can also play a role in the decision to teach in a small town. Julia began teaching in Joanstown after she moved there with her husband. Joanstown is her husband's hometown. He has been a farmer there his whole life. Nina's husband is also a teacher in New Falls. Mya said her husband is from Marshall City and that ultimately their goal was for her to work there. She taught at another school close by until Marshall City had an opening. Elena's husband is also from the town she teaches in. She said that she taught at another school for a few years before being hired to teach at Easton. The principal at Easton is her husband's cousin and he asked her to apply for the 
vacant position they had. Jacob was also asked to apply for a position at Joanstown by a former teacher of his. That teacher was a new administrator at Joanstown, and they had a vacancy. Jacob said, "I fell in love with Joanstown early on and 19 years later, I'm still here."

Nina, Elena, and Jacob were not the only teachers who found themselves in an unusual situation that led to a full-time position where they are currently teaching. For example, James took over a long-term subbing position right after student teaching and then was asked to permanently fill the role before the end of the year. Jana said that she started substitute teaching in college and realized that she wanted to get her degree in teaching. "I was actually a business major and I kind of liked it, so I changed directions. I got my associates in business and then finished my bachelor's in history and political science. Then I got my teaching certificate.” Matt said that he lived close to Marshall City, but worked in another district. He got frustrated with his administration and switched schools once Marshall City had an opening.

Melissa, from Marshall City, had quite the experience getting to where she is now. She student taught in a school with a small-town atmosphere and she really enjoyed it, so she applied at many rural schools. Once she was there, she was "bombarded with activities." She said that she was "ready to quit education forever." She got married and moved to a larger city. She ended up accepting a para position which just reaffirmed her passion for education. She said she "wanted to get back into the classroom almost desperately." The next school year she applied at all the schools around the city she was living in. Marshall City had a principal that recognized one of her references and hired her after he interviewed her. 
Caleb also had an interesting path to his position in Coalsville. He graduated with a degree in political science from the University of Missouri but found himself helping out at his family's business upon graduation. Eventually the family business closed. By this time, Caleb was married to a teacher. His wife's principal convinced Caleb to be a substitute teacher in their district. He ended up being a substitute for several of the surrounding school districts. Caleb said that he fell in love with it. "I love the kids. I knew this was something that I wanted to do." He eventually got hired to be a paraprofessional in one of the districts he was subbing in. During this time, he was going back to school online to obtain a master's in education. Before he finished his degree, a school nearby called and offered him a teaching position because he knew someone who was friends with the principal there. Caleb said that bad things usually happen for a reason. "I went from a lost child with a college degree in a recession to a position I actually love doing." He added now that he has gotten some experience and to know people at other schools that he has been offered several teaching positions at other schools each year.

Curt is a math teacher in Coalsville. He had an experience at the beginning of his teaching career that almost made him switch professions all together. He was hired to teach in one of the most prominent school districts in St. Louis, if not the state of Missouri. While Curt shared that he had the normal struggles of a first-year teacher, his principal compounded the effects in a negative way. He said the whole experience was "a really terrible experience. Like a really, really awful, awful, awful experience. It drove me out of the profession." Curt went on to get his master's in economic from the University of Missouri. While there, he found that being a graduate teaching assistant 
was what he enjoyed the most. It made him reconsider his original plan to be a teacher. Curt ended up spending the next year at home applying for jobs. He said "people didn't want to hire somebody without more experience, so it's kind of a vicious cycle. You have to get experience to be valued by districts." He applied to many schools through various websites like MO Reap and MO Teaching Jobs. Coalsville called him for an interview and the rest is history.

\section{Recruiting Teachers to Rural Schools}

Administrators discussed their approaches to recruiting teachers. One approach that was brought up by administration was the idea of having an in-house program to recruit teachers. Natalie said that she personally works with their high school cadet teachers. She encourages cadet teachers who "have a natural ability to connect" to go into the field of education and then come back to work for New Falls once they graduate college. She really believes it helps high school students realize they want to become a teacher. Ethan mentioned their school also does a great job of "encouraging our students to come back and teach." He continued to say he's been here long enough to know what high school students would make a good teacher. "We try to recruit a lot of our own people," said Ethan. Several schools mentioned recruiting their A+ students or students who are in Future Teachers of America to come back.

While the idea of building an in-house program is a creative approach to recruitment, there are other more traditional approaches also. Many school districts use various websites as a way to advertise vacancies. Joel said they attend job fairs when they have vacancies. He said it is mainly used to fill positions of teachers who are planning to retire. Outside of those traditional approaches, administrators rely on reputation to recruit 
teachers to their district. Mark said that many schools in their surrounding area respect them because "we do things right." Natalie said that New Falls relies on "word of mouth" to bring new teachers to their district. Joel said they "rely on staff to be advocates for Joanstown...Talking to others in our profession, really helps us out."

Mya, a kindergarten teacher at Marshall City, even confirmed the important role school reputations have on recruitment. She said, "Marshall City had a really good reputation. You would hear about them receiving different academic awards, how good they were in sports, and amazing things about their teachers and administrators." She said teachers, community members, and parents always shared the same message. She knew that "if I ever had the privilege of working there, with such a high reputation, I would take the opportunity."

Other teachers talked about how the rural school was the only opportunity presented to them, so they looked at it as a way to get some experience. Nora said that "I just blanket applied everywhere. It was almost like they hired me, so I took it." She said that it worked out really well and that she could not imagine teaching anywhere else now. Caleb stated, "I went to [work] at Coalsville not because I chose Coalsville, but because it was my opportunity." But he continued on to say that he loves Coalsville. He said it is a school-community that he now wants to raise his own kids in. Jacob had similar feelings with his school. He said he "grew to enjoy the small school environment." He "enjoyed the fact that you get to know all your students not just as a student in the classroom kind of way, but rather as people because they are around you constantly." Jacob and his wife both work at Joanstown now. He said they brought their kids to the school with them because they enjoy the school-community so much. "It's a family affair. And that's 
because we grew to love the town, the school, everything about it." Based on the responses from teachers, a large positive that rural schools offer is the family atmosphere. Julia said the family atmosphere is embedded within the community itself. Several, like those previously mentioned, stated they liked the idea of working where their children would attend school. While this idea would not necessarily be for rural schools exclusively, they specifically discussed being on the same schedule in terms of seeing their own children at lunch time, as well as being able to attend their children's field trips without officially having to take a day off of work.

Nicole said that rural schools offer some perks that big schools do not. She mentioned the small class sizes and lack of extra duties had influence on her decision to work at New Falls. Melissa really looked forward to having time to collaborate with other teachers specifically at Marshall City. Not many rural schools offer team time for their staff. "I was most excited about and been most fulfilled by being part of a team and that community we have created," Melissa said. Some teachers mentioned that knowing their administrators personally was also a big perk. Elena said knowing she would jive with her administrator made the decision to change schools very easy.

Stability of the school itself was another topic that was frequently mentioned. Julia said she was looking at schools with a low turnover rate, while Matt said, "having administrators that have been there long term was enormous." He had been concerned about having to consolidate schools where he taught at prior to Marshall City. "I wasn't really big on that," so that was a reason he was looking for a new school to work at.

While there are many positives to working in a rural school, it is important to understand some of the concerns people have while thinking about taking a job there. 
James said he knew teaching agriculture education would be intense without a department of teachers to support him. Where James student taught, there were two other teachers who also taught agriculture education. He said that was great because you had those other "people who can take half of the events so that you're not so overwhelmed." Curt said there were some things that "culturally, I had to adjust to." He specifically mentioned that he was not familiar with Future Farmers of America, but many of his students participated in the school club. He had to get to know what the kids liked in order to help them relate to his teaching content.

Julia said she was concerned about working and living in the same town. "There isn't any separation...It's a positive and a negative." For Jana, working in the same school she went to was a concern. It "was a little bit difficult, especially as a young adult...a lot of [coworkers] still saw me as a kid." She thought it might be easier to work somewhere where you don't have a personal connection to others. James brought in another community perspective. He said that as a parent, "there's a limited number of courses that [your kids] can take. [The school] doesn't have a big course catalog." He thinks the biggest limitation for him was thinking about how many opportunities and extra-curricular activities are available at big schools in the surrounding areas when it comes to his own children.

Once Nora started working at New Falls, she said she was concerned about only having one principal while implementing new practices. She said her first principal would "want to start a program, but then wasn't able to provide us with professional development to see it through." Her principal was too bogged down because of all the tasks she needed to accomplish. Melissa was concerned that she would be the only 
teacher teaching English at her school. "I worry constantly that I am not doing enough of the right lessons. Being responsible for all four years of a student's English education is a big responsibility." Matt brough up school consolidation and Cara echoed that. She said she will always be concerned about enrollment, budget cuts, and the school climate. Coalsville is steady in all of those areas right now, but it tends to eb and flow in their community.

\section{The Hiring Process}

Administrators described their current day hiring practices. Ethan, from Marshall City, said the administrators in his building narrow down applications to those they want to interview. They bring in those applicants and ask them some pretty standard questions. He said it is more important to "get a feel for what that person knows and how they will fit into what we're trying to do." Ethan mentioned trying to get a feel for the applicant's future plans. He said that they prioritize people that they think will stick around. "I don't want to be interviewing someone next year for that [same] job."

Joel's approach to hiring is similar to Ethan's in the sense that the administrators are the ones working to hiring new teachers. Joel said that he and his superintendent look for people who "have a lot of energy and are willing to do a lot of different things...someone who is approachable, sensible, and will fit into Joanstown...they just have to be grounded" because the community is grounded. They really try to prioritize the applicant's values. Will "their character mesh well with the community?" They want their team of teachers to be "a cohesive unit," specifically in the sense to be able to "set asides your personal differences and work towards promoting the growth of your students." 
Cooper said that they try to have a very personal approach to hiring in Coalsville. "We walk around the whole campus and just talk to get to know them." Cooper prefers to do this during the school day so that applicants can see the kids learning. "They can actually see the true day to day operations, not just an empty school building." Cooper mentioned that he likes to hire the best candidate whether he thinks they will stick around or not. He said, "you never know," when talking about if applicants will stay, "they might just love Coalsville and want to be there for the next 25 years of their career...but for next year we've got them and they're gonna be good."

Natalie said they have adopted a new approach to hiring at New Falls over the years she has worked there. She tries to have a team approach by bringing in a committee of teachers to interview applicants. She likes having the help to "get a good read on our applicants to see who would be the best fit." Marshall City also puts together a committee to hire teachers. Mark said that they like to see how much the applicant had moved around. "Have they been with a district for four or five years in a row" or have "they been at six districts in eight years?" The latter would raise concerns for Mark, red flags as he called them. He said they just hired some teachers who both have some ties to the school as they were previous student teachers. He felt like they would stay in the community. He said hiring people like that are nice, as "we can actually groom them and get them started the way we want them to be started." He said he likes to leave applicants with this teacher committee to answer a few extra questions. He thinks that applicants open up or relax a little more without him in the room. In his eight years as principal, Mark has only had to hire six teachers. All the administrators agreed they felt successful in hiring long term teachers. 
Teachers shared how their hiring process went. There was a wide variety of stories that came along with interviewing. For example, Curt said he felt like his interview process started the moment he got into town. As he was driving into town, people started waving at him. "I was in an unfamiliar car and there was someone who waved at me. That was my first experience in Coalsville.” He was from the St. Louis area so that was a new experience for him. As for the interview itself, he met with the principal who "asked a couple of friendly questions and they gave me a quick tour." Curt wondered if "maybe they were trying to feel out my interest to see whether I was really interested in Coalsville or not."

Elena from Easton said, "mine was quite different than probably most peoples." She got a call from her husband's cousin who was the principal, "he said 'I need you here"'. Elena then went in to meet the superintendent who asked her some questions. James's hiring process was also different than most. He joked that he "never actually interviewed for this job" when he was asked about the hiring process. James was filling in for the agriculture education teacher at Joanstown when the superintendent came to him and said, "the job is yours if you want it." James said that they later sat down and talked more specifically about the job but he "never really had an interview."

Nina also found herself in an interesting situation when she completed her Teaching Fellow's internship. "I think I just kind of slid into my spot," she said. Nina said that New Falls had an opening when she would have needed to start looking for a full-time teaching position and her principal told her that they were going to hire her for it. "I lucked out. I graduated at the right time. There was a spot opening up, so timing was on my side." Jacob was also in the right place at the right time. He went to a job fair at 
the University of Central Missouri where he ran into a past teacher who was now the principal at Joanstown. Joanstown had a social studies opening and Jacob was certified to teach social studies. They ended up meeting at a local restaurant to discuss what the teaching schedule would look like. Jacob said that coaching was expected with this position and he said, "bring it on...I'll coach whatever sport you want." He said as a young teacher, he was ready to take whatever roll they wanted him to. "The interview process was simple, painless. It was informal and the rest is history.”

Jana said she met with the superintendent at Joanstown when she was interviewing for her position. Her interview process "was pretty laid back." He asked her to just come in and talk with him. "It didn't feel like it was that much of an interview. It was more of a discussion." Jana said it "felt like a good place to be, so there wasn't a lot of thinking. I just said yes and kind of jumped on board." Cara said her interview was also very simple. "It was just the superintendent and the principal...I kind of knew both of them as well so that was kind of different, you know." Administrators knowing applicants is not uncommon in rural Missouri. Julia said she knew the superintendent. She said her hiring process "was very informal." Emma felt similarly. She was called in to do an interview with the superintendent at Easton. He recognized her maiden name. Through conversation he realized that she was related to some friends of his. Afterwards, she interviewed with the Board of Education, where they hired her on the spot.

Melissa said that while her interview was formal, "it was very conversational." She liked that a lot. "It was less Q and A and more let's just talk." She said that they hit all the important topics during their conversation. Melissa said that Marshall City's next principal interviewed the same way. "I think they knew what they were looking for." 
Matt said that his interview was formal "but it wasn't overly formal" because he knew the principal he interviewed with. "I had a good relationship with him." They joked about how long Matt would stay before he took farming on full time. Once Matt got in there, he decided that he was "in for the long haul."

Mya "always knew I wanted to be at Marshall City." When she finally had the opportunity to interview for a position, she met only with the outgoing principal and the incoming principal. Mya felt like their "questions were very in depth. They were good, thorough questions." She said that she felt like she would be a good fit based on their conversation. Nicole had a similar situation as Mya. She interviewed with both the incoming and outgoing principals and then two teachers. One was who she replaced and the other ended up being her mentor. Nicole mentioned that they still hire people this

way. She feels like the different people offer "different perspectives on the job." Nicole was a student teacher in the building and felt like she had "a different experience than a normal hiree." She knew she wanted to work in New Falls because she liked the environment and already felt comfortable with the curriculum and routines.

\section{The Induction of New Teachers}

The induction process looks different at every school. In the state of Missouri, schools are required to pair brand new teachers with a mentor. Cooper discussed how important those mentors are. He said, "making sure that they're paired with teachers that have been here for a while, so they know how we do things." At Coalsville, they try to pair up teachers by "content area or grade level." Outside of mentoring, Cooper likes to offer a lot of professional development opportunities. He likes to "bring in subs and then send our younger teachers to different schools." He said his teachers really enjoy that. 
Joel from Joanstown said they have an onboarding program he thinks is "really important. It shows the new teachers the Joanstown community. It takes them around to some small businesses and lets them get to know the parents." He said that giving his new teachers a visual of the community they are serving helps prepare them for the start of school. Joel also feels like the mentor program is "really beneficial to our new teachers...We've really had good success with that." At Joanstown, they also use observations to tell new teachers what they are doing well. "I think that gives our new teachers a great deal of support."

Natalie has a professional development committee that she works with to support new teachers. They set up time to meet with the superintendent, the tech department, among others. She said that it provides them with "the nuts and bolts of what they need to be able to do." Natalie said they also take new teachers out to lunch to try to "build rapport with them." She said that time also provides new teachers an opportunity to meet people in their community. She also mentioned their mentoring program is a success for New Falls. She said that while they have the program designed for the new teacher to meet with their mentor at specific times, "most of them are meeting more frequently." Natalie likes to pair people up who normally would not work together on a daily basis. She feels like that provides new teachers "an out" if they have "some kind of conflict." Mark also mentioned the state mentoring program. He said they like to pair new teachers up with a mentor in their same grade level at Marshall City. Mark called this a horizontal mentor, but he also mentioned they like to provide a vertical mentor for curriculum purposes. That way, "we have at least a couple of individuals that are meeting with them regularly to try to give them support." Mark said that keeping his door open 
for questions or time to talk is important to him. He thinks "it builds relationship and comfort" with new teachers. Mark also likes to ask his staff what he can do better to support them. He believes that it provides ownership in their work.

Jacob discussed working with his mentor at Joanstown when he started. He said, “it wasn't very formal with him, which was awesome for me because I'm kind of laid back. We just had conversations and hung out through that process." Jacob liked that he really got a "feel for how to get things done." He said that he continues to learn that way from others all these years later, and more importantly, he hopes that he's "teaching some of the others along the way too."

At Joanstown, Jana remembers meeting with her mentor at the beginning of each month. She said that they would "go through a checklist of things that I needed to make sure I was doing." Julia said she had a mentor and extra professional development when she started in Joanstown. The meetings were basically "how we do everything here," she said. James, also from Joanstown, said he did not necessarily go to his mentor with questions. He chose to go to one of the teachers across the hall from him most of the time. While there was not any kind of induction program when Elena started working at Easton, she became friends with the teacher who taught next door to her. Elena said, "she got me through the first few years."

Melissa also had easy access to her mentor. They shared a common plan time and met weekly with their team. She said that her mentor "was fantastic...she was just really supportive and think we had really good chemistry together where our personalities just really worked well." Melissa and her mentor had the opportunity to co-teach a class. "I learned a lot just from watching her teach," Melissa said. She also remembers that it was 
not uncommon to have her principal come in and teach her lesson. "I could see how she interacted with kids and how she kept control... how she responded to different behaviors. I learned a lot by watching them model." Melissa continued sharing how wonderful her mentor was. "She was always available for me to just pop in and ask a question." Melissa joked about how her mentor never got annoyed with her. "I really don't know how because I had a lot of questions that first year."

Caleb said he also had a great mentor. "He did an excellent job. He was very considerate and understanding." Caleb believes that his mentor remembers how horrible his first year was at another district and does not want other first year teachers to have the same experience. Caleb finished by saying the people were worth noting. "It was easy to ask questions. I never felt uncomfortable asking anybody questions.”

Mya said that she thinks that mentoring is a necessary component for new teachers to be successful. "Training, orientation, and mentorship, they are just so crucial to the induction process. [It helps] you get to know everything." When she started working at Marshall City, she had three days with her principal. "We went over all of the tiniest details and I thought that was so important to me. I was prepared and knew what to expect."

Some teachers had a slightly different take on their induction process. Emma from Easton said they "did not have a formal mentoring program" but "other teachers were great about reaching out and letting me know need-to-know information." Emma said that her principal was always available if she needed something. Curt did not think mentoring made an impact on him at Coalsville since it was his second-year teaching, but 
he did appreciate the support he had from his principal. "My classroom was right across from the principal's office...if I had a question, I stuck my head in."

Nora attended some back to school professional development the day before the rest of the staff came back. She said they met the superintendent and learned about all the technology they would use. New teachers were then given a handbook that had details about everything they covered during their back to school professional development. She liked having something to refer back to. Melissa had a handbook and also attended some back to school meetings for new teachers at Marshall City. She said her principal was in charge of the orientation. "She went through everything with us."

Some teachers who switched districts did not need a mentor because of the number of years they had been teaching. Matt said he did not have a mentor at Marshall City "because I had been a teacher for seven years." They did have extra professional development for teachers new to the building the first couple days of their contract. Nicole was in a similar situation. She did not need a mentor but remembered attending professional development for an extra day as a new teacher to the district.

\section{What Makes Teachers Successful}

Success comes in many forms, according to participants. To Nora, the success may be in test scores at the end of the year or it might be smaller wins throughout the day. A student "saying, 'thank you so much for everything you do for me.' You feel acknowledged, that you're doing something right...that you have made a difference." Success can come in big or small forms, like Nora mentioned, or sometimes it may fall in the everyday actions you take. Julia said she works hard to be connected to the 
community. She feels like she can be most successful "connecting to kids and to families."

Cara feels like she has "really good rapport with parents, students and fellow colleagues. I feel like that's really helped me be successful.” Relationships are key in Marshall City. According to Mark, to be successful in a rural school, you have to build great relationships with the whole school-community. "Relationships just have to be the biggest thing in my book." Cara and Caleb both agreed. It's "most importantly about enthusiasm and caring," according to Caleb. He continued on to discuss how students will not learn from teachers they do not like.

Student learning is always an indicator for teacher success, according to Natalie. "Not only are they learning, they're enjoying learning." She feels like she "can tell when teachers truly love what they do." Most of it is their interactions with kids while another portion of it is their attitude. James made a good point. He said that student success may look different to different people. As an agriculture education teacher, he believes that not all of his students are good test takers, so when he has a kid who can build something in one of his classes, "I view that as success every time." He thinks that when his students look back at their education, they will be thankful for the things he taught them and that is success.

Teacher success is holistic for Curt. He sees success in the classroom but discussed more of the long-term effects that success may look like. He enjoys when students come back and tell them how they are doing. "That's the ultimate way that I can know that I have made an impact on them mathematically." Matt, like many teachers, agreed. He talked about how he attended the wedding of one of his past students recently. 
He enjoyed hearing how he "prepared them for the real world." That feels like success to him. Emma said she feels success in the same way. "To me, teacher success is when your former students go out and build their own lives that are productive and happy."

Elena puts in a lot of time preparing her students for the real world. "That's probably my biggest [success]." Curt shared that he, too, feels "like I've done my best and I put a lot of time into what I do.” As the principal in a rural school, Natalie recognizes that successful teachers are willing to put in the "extra time without expecting anything extra." It's their passion that drives their success, according to Natalie. Successful teachers love seeing students achieve their goals. Jacob also sees student success as his ultimate success. He feels like he is successful because "I've made an impact." The connections he has with students and their families is something he will cherish for a lifetime. "I've touched lives. That was always the goal...That's been my success.”

Jacob said teachers who embrace the small community are the ones who are most successful. He said most teachers jump in to all the different roles that are available at a small school. Nicole agreed. Many rural teachers often wear multiple hats. They are not only a teacher; they are a coach, a class sponsor, and usually much more. She said that "collaborating with my colleagues has helped me become successful, otherwise I would have probably just drowned." In terms of thinking about the whole school-community, Cooper feels like all teachers need a supportive administrator in order to be successful. Teachers "need to be provided the resources" because if not, they are not able to do their jobs effectively. 
Melissa attributes all of her success to her first administrator. She "modeled to me what a strong teacher, educator, and leader is." That principal taught Melissa how to use data to support her work. She showed her strategies and how to troubleshoot. Nora also had an administrator who really showed her the way. "I felt like I learned what the heck I was doing." That administrator brought in programs that benefitted her students and she showed them how to use it. "I just really felt like that truly helped be become a better teacher."

Mark believes one of his most successful teachers has been so because they have worked to keep her in the building. They have provided in-service time for her to lead in their building. "Whenever she speaks, the teachers listen. The kids listen." Caleb feels like the most successful teachers "never stop learning. Until the day you die, always try to learn more. Every day, learn something every day." Melissa takes learning to the next level. "You have to be willing to grow, to try new things, and to accept constructive coaching." She wants someone to share new ideas with her. She wants to "step my game up. I want that feedback because I want to continually grow.”

Natalie believes her teachers are successful because they have a "drive to always improve." She said her most successful teachers have a willingness "to want to learn new things and to be stagnant. They realize things are changing and are able to embrace that." Mark agrees. Successful teachers are "self-driven. They are not afraid to try something new or think outside the box...they push themselves to get better and better each day.” One of Mark's most successful teachers is ambitious. "She really goes above and beyond." 
Joel thinks many outsiders think test scores and attendance rates are used to know if teachers are successful. While he takes all of that into account, he feels like teacher success is something you see when you walk into their classroom. Students are "engaged in the content, interacting with you and with each other. And when I see that on a consistent basis, I hold that teacher in high regard. I know they're a great teacher."

\section{Opportunities to Collaborate}

Knowing that collaboration can help teachers be successful, teachers were asked about the opportunities they are provided by their school. Each district seemed to have a different set up that worked for them. In Easton, they have a variety of meetings, but nothing set in their schedule. Emma said that much of her collaboration revolves around getting background information on students and technology. "I'm pretty much on my own as far as planning my curriculum," she said. Elena calls some of her team's best collaboration "hall conferences." They occasionally meet to discuss what kids need extra support, but do not discuss professional development until it is built into their calendar by the district. Ethan shared that extra duties, such as lunch supervision, is covered so that teachers can meet during those moments. He thinks having that time is "really helpful." Ethan said the district tries to find collaboration opportunities outside of Easton for teachers. We "try to identify professional development opportunities for each individual person...because your specific needs for professional development might not meet what mine are as another teacher."

Natalie said some of her teachers have common plan time at New Falls. Since most of that time is spent working through student concerns, she tries to have vertical teams meet during their professional development days together. This is especially 
"beneficial when you have new teachers because it's not like you're just going in there by yourself trying to figure it out." Other collaboration opportunities are driven by a needs assessment. "We try to base professional development off of [our online survey]," Natalie said. Nina feels like her voice is heard when it comes to collaboration. "It's not like a stadium and you've got all these faces and you're not really sure who's saying what or whose idea it was. If we have an idea, it's listened to."

Nina also appreciates that she has a common plan time to meet with other teachers. She mentioned they will also meet quickly after school as needed. Being flexible is easy in a small school. It is not like they are "trying to work around a bunch of people's schedules." Nora does not have a common plan time with other teachers consistently but brought up the days that they get to work together on curriculum. She said that teachers "do curriculum work at least twice a year." It's usually at the beginning and end of the school year, built into their calendar.

When asked about having the opportunity to collaborate, Nicole said, "it's really been nice because our curriculum director has set up days at the beginning of the year for us to pick a school district that we want to go see for the day." New Falls sends teachers to other schools to collaborate with teachers who are using the same curriculum. Natalie said that they send teachers to other schools who "we've heard are successful and have good programs...it gives [our teachers] some insight and it's new scenery for them to get new ideas.”

Mark established a leadership team at Marshall City over the last few years. He uses this team to help determine what kind of in-service teachers need. The district is working hard to create vertical teams to guide their curriculum work. "What we're trying 
to do is have our middle school core teachers meet more with our high school core teachers, so we know what to expect when they come up from eighth grade to freshmen." Mark continued on to say they are doing the same work in their elementary levels, too. Mark said he also likes to utilize his teachers' strengths during their professional development time if it is relevant. For example, he has one teacher who leads their technology work in Marshall City. "She's really good about providing professional development to our staff, as a whole, on in-service days...she's good about showing teachers new things or different things to try in the classroom."

Matt said his team meets once a week. During their plan period they "go over kids that we think are at risk. We go over data, not only grades, but also how many kids have absences that week. And also, behavior...who needs a mentor, who needs extra help.” Matt feels like there is constant communication between his teammates. Melissa said while she is very connected to her team, she is concerned about the divide that may exist between elementary and secondary teachers. "When you walk into in-service, we will be in one big room, and all the high school teachers will be on the right, and all the elementary and middle school teachers will be on the left." With this being said, she knows the leadership team is actively working to unite the school. They "have been making progress," she said, "they're still trying to build a level of trust there."

Joanstown collaborates with conference schools at the beginning of the year. "All the principals and superintendents come up with a lot of the topics that are going to be covered there, but we also take teacher input from the year before." Otherwise "a lot of our [in-house] collaboration happens during professional development before school starts," according to Joel. He said that "it's hard to get a shared plan time with teachers 
across a certain grade level." Additional professional development opportunities are built into their calendar quarterly.

Jacob painted a picture of how he is the only one teaching his subject. "There's no double up...it's not like we have to figure out lesson plans together...there's no shared responsibilities." While Jana is in the same setting, she thinks of collaboration as getting together to "just bounce ideas off each other," which happens often. "We're small enough to kind of do our own thing but then hit each other up if we have issues." James said that he also likes to reach out to teachers in a quick manner. He prefers to collaborate with teachers who handle problems in a similar style as his. "I'll bounce some ideas off some other teachers that maybe are just a different type of teacher than I am, but I more so go to the ones that have a better understanding [of my style]." When it comes to agriculture education, agriculture education teachers are constantly going to meetings together all summer long so that is a lot of their collaboration. With being the only agriculture education teacher in the building, there's not a lot of collaboration that happens otherwise, according to James.

Cara had an interesting position at Coalsville, as a special education teacher. She felt like she had the opportunity to collaborate more often than her grade level peers. "I had to have a lot of input from the teachers... about the kids I was working with when I was trying to do an evaluation." She used technology to communicate on a regular basis. Caleb, on the other hand, thinks he could do a better job collaborating on interdisciplinary units with teachers. When he "got into education, that was a big thing." He said that he's tried to link up units with other teachers, but the timing just has not worked out well. One thing he feels like his school does a good job of is communicating concerns about 
students with each other. They "generally find there's an underlying issue" when there is something abnormal going on with their kids. Coalsville does a nice job helping students through individual situations.

"I'm the only math teacher" at the secondary level, Curt started with, "so as far as collaboration, it's a pro or a con depending on one's personality." He's not a fan of forced collaboration. "I'm glad I am able to do my own thing." Curt mentioned that Coalsville has collaborated with other schools in the area. He called that official collaboration but said other collaboration happens inside the building. Curt gave an example of how the art teacher integrated some of his quiz bowl material into her lessons. He joked that "there are weird ways that we can collaborate because we are in such close proximity" to each other.

Cooper mentioned how hard it is to have true professional learning communities with a staff so small. He said the staff just "gets together to talk about things that need to be talked about...We have an agenda." Cooper likes meetings to be meaningful. He tries to keep conversations to those that will "help the school as a whole." He said the district does dedicate the first few days back to school to collaboration.

\section{Administration}

Mark, principal at Marshall City, feels like his role with new teachers is very important. He said his support is non-stop. "Those first-year teachers, I just really try to get in their ear a lot." He tells them how great they are doing and asks what he can do to help. "Those first few years are tough and depending on your environment, you know...I don't want them to be discouraged right off the bat." He continued on to say that anytime 
there are areas for growth, he always expresses his thoughts in a "polite, confident, and nice way without breaking down somebody's neck all the time."

Natalie takes on many roles as a small school principal, but she feels like one of her main roles "is to be their cheerleader. I think keeping staff morale up is a big part of keeping good teachers. Making them feel valued and doing what I can to eliminate extra stressors" can make a big impact. Cooper had the same kind of idea when it comes to supporting staff. He feels like a big part of what he does on a regular basis is build relationships with new staff. "I just try to be supportive, it's my biggest role...Just being supportive any way possible" is what is most important, he said.

When asked about their connections with administration past and present, teachers had a lot to say. Many teachers echoed what was heard from principals in terms of support. "He's been a great principal," James said, "he’s supportive, he's there for you." Elena thinks that everything is "very positive" when it comes to working with her principal. He is always "professional, never nitpicky." She often hears how much he appreciates the work the teachers in the building are doing. "What can I do to support you?" is often a phrase he asks the staff. Jacob said that his principal "has an energy about him that is really good." He creates a "very pleasant work environment" and Jacob appreciates that.

At Coalsville, Caleb says his superintendent is "completely empathic and understanding. He likes to listen. He doesn't like to tell people what to do. He likes to hear people's input. And that's huge for me." Caleb is fortunate to have multiple supports. "I got lucky. I am in a small school that cares. My principal, she loves me. We 
get along great." His superintendent was his high school principal when he was going through school, so he also liked that.

Julia works specifically with several federal programs. She said that means her "principal is very involved" in the work that she does. Cara also worked closely with district administration because of her role with the early childhood special education program at Coalsville. Many teachers, like Nora, mentioned working with their principal on various committees. "She's always asking what we think. She wants to hear from us." She says that in particular, their principal's advisory committee meets to discuss what went well and what needs improved. Overall, Nora feels like her principal is "pretty supportive of us." Mya also holds a special role in her building. She is on the leadership team. She said she and her principal check in a lot. Mya just likes to "make sure that we're on the same page." They communicate frequently. "I'm glad that I have the opportunity to do that because I feel like I can speak freely with her."

Caleb is the same way. He said he appreciates that he can vent on the phone with his superintendent. He said they "just hit it off really well, professionally and personally. We've got a lot of common interests. We're both pretty level-headed people." He said he communicates with his superintendent several times a day. Caleb thinks that communication "is key to a successful school...Nothing frustrates the community and the staff as a whole" like the lack of communication. Caleb also likes when his principal asks for his opinions on decisions, too. He said that is just a small piece of why he "loves his administration."

Many teachers feel like they know their principal on a deeper level because of outside connections. Nina is a great example. She has kids that are friends with her 
principals, their husbands are both active in agriculture groups connected to the school, and their families attend cattle shows together. "I think it's because we are smaller. We know each other outside of school." Nina feels like she can always call and check in with her principal. She really has an open-door policy. "You don't really have to go through too many loops. You can just say 'hey, I need to talk to you' and she's available.” Jana said her administrators "stay in good contact with teachers, checking in to see how things are going." Emma's principal is "actively involved and makes rounds regularly." He also trusts teachers to do their job. "He treats us like professionals, while at the same time caring about our lives." Matt said his principal used to teach and coach at their school, so now that Matt has taken over the coaching duties, during the season they talk daily. "I just look at him as a leader. He's somebody I've always respected. Everything that he did, he went about it the right way. He's super supportive of me and I just really enjoy working for him."

Melissa completely attributes her success to one of her administrators at Marshall City. "I had a stellar, stellar principal. I would not be the teacher that I am without her." She continued to say that "she has her hand in every part of [what I did] and it was guiding and supporting the entire way." This principal offered to sit down with Melissa when she was overwhelmed with work. She even went so far as "buying a writing program that would give kids automatic feedback just to help alleviate some of my work."

An interesting fact is that many teachers in rural schools feel connected not only to their principal, but also to their superintendent. James' current superintendent periodically just "pokes her head in the door to see what's happening." Curt said similar 
things about his superintendent. "It's very easy to pop my head in...and say, 'hey."” Jacob, when asked how many administrators he has worked for, counted his superintendents. "I've been very fortunate that I haven't had to work for a lot of different people." He thinks that many people who have worked there as long as he has "have enjoyed our administration." Jacob thinks something that sets a small school apart is the "level of access I have to my superintendent. The office is just down the hallway from the principal's office." Jacob said his superintendent "is a really good leader. She is really personable" and something that he appreciates is that she is able to make a direct and clear decision.

As Curt continued talking about how much access he has to his superintendent, he reminded me of his poor experience at his first school with his principal. He said that if he would have been able to walk down the hallway and have the support of his superintendent in that situation, there may have been a different outcome for him. Curt compared his first year with an administrator who was vindictive to his next experience that he had at Coalsville. "Ultimately, this is why I am here. It is the people that are actually trying to help you succeed as opposed to get you. That's a huge thing."

\section{The Rural School Design}

Teachers and principals were asked to describe their school. They mentioned everything from what their role looks like in the building, to their bell schedule, to their feelings toward the school. Marshall City staff had nothing but great things to say about their rural school. Mya said that Marshall City has a great reputation and amazing teachers. "They are really what runs the school. We're super fortunate to have the teachers we do." 
Matt mentioned that their middle school design may be different than others around them. Their elementary school holds kindergarten through fourth grades, then fifth grade is in their middle school. Middle school continues through eighth grade. Matt, and many teachers in other districts, mentioned that middle school teachers also teach at least one high school course as well. School starts at 7:45, which is earlier than other schools in their area, according to Melissa. Something a little more common at the middle school level is that there is only one teacher per subject in Marshall City. Their classes are 45 minutes long and they have eight periods a day.

Melissa continued on and described her hallway in their building. It holds all four core teachers and their superintendent's office. She said the middle school is very isolated. There are lockers all down the hallway which makes passing time very crowded. "It's a lot to manage." Melissa is the middle school team leader and she makes sure that her team meets weekly. "We have a different agenda that we go through every single week. That way we know that we are monitoring academics, behavior, and incentive plans." Her team also discusses upcoming events, supervision duty, and special education students. "We especially talk about students that are really struggling in our classes." They try to work as a team to figure out what will work best for students in terms of success. All-in-all, Matt feels like "it’s a very community family approach to school." In Easton, teachers had similar feelings toward their district. Ethan was excited to talk about his school. "We've got great history in academics and athletics. We just take a lot of pride in trying to do good in our community...We try to do things the right way...We're ultra competitive but also respective and humble." It's "a very caring school. There is a lot of support on all levels," according to Emma. She said that "everybody has 
each other's back. Knowing that helps balance out the fact that our work loads are heavier than at a larger district." Emma described what she meant in terms of workload. As a teacher at Easton, she teaches six different courses and teaches however many students enroll for the course. For example, "if there are 33 freshmen, I have 33 freshmen in my English I class." Emma continued on that "teachers at Easton get to be jacks of all trades." What she means by this is that they teach a variety of courses, coach various sports, and usually sponsor at least one club. "Teachers here do what it takes to help our students."

Elena described what the layout of the building is like at Easton. "We have one building at the high school. It's an old building, but it's really nice." The middle school is just two classrooms in this building. Both teachers teach two subjects. "Then we have a separate campus that has our elementary in it." There is only one teacher per grade in Easton. She said they were awarded a grant that allows them to have some interesting after school programs. Some of the activities include cooking, painting, or sewing just to name a few. "It's a safe place for kids to be after school and still get to do something fun.” Elena mentioned that the community is also invited to participate in the after-school activities.

Easton has implemented some innovative strategies to retain teachers in their part of the state. Elena shared that a school close to them moved to a four-day school week. Teachers "want to do that so [our district] changed our calendar to where we get out of school on April 30." They have also tried to implement training videos rather than having in the building professional development. For example, instead of their active shooter training taking place during one of the school days without students in the building, 
Easton has provided a video that staff needs to watch on their own time after school hours. This allows them to save a day at the end of the year on their calendar. Elena felt like this was more flexible for teachers. She also mentioned some staff bonding opportunities that really excite teachers. "Last year we went to see Gary Brooks, he's a hoot." She continued on stating, all year "we'll find something like that to do...We're a lot about working together and community."

Joanstown is a very conservative community, according to Jacob, "and the school reflects that." He continued on to say the town is very agricultural and that many families commute to their jobs if they are not farming. Jana agreed, "it's a small town of about 400 , a very rural community with a lot of farmers and blue-collar workers." Joel said, "I would highly recommend [Joanstown] to any new incoming teacher. I think it's a great place to start your career." The school itself has about 200 students, kindergarten through twelfth grade, all in one building. Joel bragged on his students, saying they are "absolutely fabulous." He said the biggest concern about students he has as an administrator is that they do not all turn their homework in. Jacob shared there are an average of 15 students per grade level in Joanstown. According to Joel, "they range from really high achieving to those who need a little more support...but overall I couldn't ask for a better student population."

Joel said the same thing goes for teachers. "We have a wonderful teaching staff." He said most teachers are always willing to jump in and lend a helping hand. "Rarely do I hear complaints when I have to ask someone to serve as a class sponsor or help out in another way." The school day in Joanstown is seven periods and being tracked by minutes this year instead of days. Julia said teachers' contracted time begins at 7:30. Most 
teachers have some kind of duty in the morning and at lunch time. Due to the size of the school, Jonestown only has one teacher per subject. It "can be tough," according to Joel, "but it also makes them get out of their comfort zones a little bit to collaborate." He believes the cross curricular units provide increased opportunities for their students. In Coalsville, there's about 120 students in pre-kindergarten through twelfth grade. "We're pretty small. I mean, really small," said Cooper. Cara further explained they have teachers teaching multiple classes at the elementary. For example, "kindergarten and first grade are in the same classroom, so there's only one teacher in there." This year is also the first year sixth grade is considered part of the middle school. It went "upstairs to our middle school and high school floor...in the past, sixth grade has always been in the elementary." This decision was made to help with their budget. This allowed the district to not have to hire a teacher solely for a small sixth grade class. This district is unique because it also has an early childhood special education program within it. "We're the only [school] in this area that does. We actually have kids come in from other school districts just for our program."

According to Cooper, Coalsville annually sets a goal to have a good annual progress report score, but ultimately the goal they work the hardest towards is seeing kids be more successful than the previous year. Cooper was very complimentary of the students. "We have good kids. We don't have a lot of disciplinary issues. Students know the expectation." Curt said many high school students attend a local vocational school during the day for course work. Many of his student's plans for after graduation revolved around going into the workforce. "But in every class, there is at least one student that would say they want to be an engineer" or something similar. Curt enjoys having a 
diverse group of students. He really appreciates when former students come back and discuss the higher-level math courses they had to take in college. "That's very rewarding to me," he shared.

New Falls is the largest school used in the study. They have two teachers at each grade level. All teachers referred to the additional teacher at their grade level as their grade level partner. Nicole is fortunate that she and her grade level partner get along so well. The principal at New Falls attempts to schedule grade level plan times so teachers and their grade level partner "have at least one or two shared plan times a week where we can get together." Nicole also shared they also team vertically often.

When school starts, teachers and students participate in a morning meeting. They have them for each day, say The Pledge of Allegiance, go over announcements and birthdays, then begin their classes. According to Nora, that "just builds that community within the school." Nicole shared that they are "pretty lucky. We really don't have many extra responsibilities." She mentioned they have recess duty about once a month and have to stay after for a few school events.

Nora also shared that New Falls was one of the first enhancing Missouri's Instructional Networked Teaching Strategies (eMINTS) schools. “That's a big recognition.” They were also one of the first University of Missouri's Partnership for Educational Renewal (MPER) schools. New Falls also participates in special events like Red Ribbon Week. The guidance department "comes up with activities to get all the students and the staff involved."

Many teachers have mentioned they are always trying to improve. Nina said New Falls focuses on classroom management techniques and technology. Every student in 
Nina's classroom has their own Chromebook. The teachers in the elementary have a sheet with various tech related resources on it to help support teaching and learning in their classrooms. More importantly, New Falls makes it a priority for their school to be somewhere "the kids feel like they have a safe place to go," according to Nina. School is where "it's their safe place...where they are going to learn, and they can be a kid."

\section{The School-Community}

Making yourself visible is important to Marshall City's school-community, according to Mark. "That's how you build relationships." He also said the "community has a tremendous amount of support." Matt echoed that. "The things that sticks out above all else is the community support behind the school. The school drives the community and the community throws it's full weight behind the school." Matt truly believes the community is the reason why the school has been so successful for so long. "Marshall City has a great reputation of the school and the community working together." Matt shared how the trickle-down effect works in their school-community. The school board "supports the administration and the administration backs the teachers." He says this is “one of the reasons that I've stayed as long as I have. I feel like I have support from the community, the school board, and the administration."

When Mya got to Marshall City, she's "never seen so much community support whether it's from churches or local businesses. Organizations just reach out to you." She also feels like parent involvement at the elementary level and at school events, like ball games, is extremely high. "I feel like we are very fortunate to have great community support. Mya mentioned the school board comes in to visit classrooms once a year at Marshall City and then "as teachers, we also attend one board meeting and present about 
our classroom." Melissa thinks this is a great way to foster a relationship with the community. Marshall City, being a small town, Mya knows all of the board members personally. She "feels comfortable to talk with them" at any time.

In Easton, "deer season is not only a holiday, but for many local families, it is the best they will eat for months," according to Emma. She continued on to say poverty is high in their community and that parent involvement during the school day is comparable to other schools in the area. The district has begun an after-school program that is encouraging more family involvement than before. Emma shared that "we do have a great school board" and "a lot of community involvement with athletics." Elena agreed that there is a great deal of community involvement beyond the classroom. "This is the fourth different school [I've worked at] and I'd say it's the weirdest school I've ever taught in. The community here within the school and the community itself is very family based." Elena shared that while their town consists of only 600 people, local businesses sponsor a lot of activities. She agreed with Emma stating that their community has a lot of great leaders in it.

Schools like Coalsville feel "like a different world." Caleb joked about how he feels like the rules do not always apply the same to people when you are actually in Coalsville. While rumor mills can be tough in small towns, the neighbors are friendly. He said Coalsville is the kind of place that if you need flour, your neighbor would give you some. "There's some upsides and some downsides." Things can get rough when you try to change something at school, according to Caleb. 'It's difficult because a lot of people are set in their ways and they don't want to change certain habits or rituals." He continued on to tell about a story of how Coalsville and another school combined their 
athletic programs roughly five years before he started working there and how hard it still is for some of the community to accept it. "It's my understanding that [the year they combined teams] was an absolute nightmare." Coalsville is proud of their school and there's nothing wrong with that. "Our school's really all that [our community] has," according to Cooper. He loves seeing everyone come together whether it is at a ball game or another school event. The stands are "packed. It's always packed...We have plenty of people that show up, so it's a good dynamic."

Curt said Coalsville has a Coalsville community day each year that many people attend. "It was fun," he said. Cara said their community is very positive as a whole. "Everybody's here to help each other out...Because we are so small, everybody just pulls together." Cara discussed how involved the community is in their athletic programs. "The community really supports our sports teams." Curt and Caleb both talked about how they enjoy parent teacher conferences. Curt shared that "another thing I value about Coalsville is that...the community values the school." He said many parents do not challenge teachers, which can be a curse and a blessing. He wishes some parents would put more of an effort into their child's education. "But they care about the district" as a whole, he shared. He feels like the community has to be this way or it "would be shuttered." He wrapped up by discussing how many other districts have been consolidated around them. Cara agreed. She stated the school is "the heart of the town."

Caleb likes how "every community is a little different" when you are discussing rural towns. He also thinks there would be many similarities when it comes to schools. In Coalsville, everybody knows everybody, and Caleb was not the only teacher to mention that. "I would say it's pretty tight knit when thing happens. If somebody needs help, 
they're there to help. There's also a lot of gossip." Caleb joked that he does not like to participate in that kind of stuff. He feels like Coalsville "has an excellent school board. They're very supportive." He shared an example of how the school board gave every employee a little gift during the holidays. "They're very appreciative of what we do as teachers...they show appreciation for what we do. It might not be a lot, but it means a lot to me." He said he knows all the board members very well. "There's not a lot of selfserving attitudes on our school board."

New Falls has a very active parent organization. They have "aides that come in to help read with the kids or laminate," said Natalie. "We have a very supportive community, so we like to keep them involved." The school loves to showcase their work at grandparent's day or the winter program. There's about 1000 people in their town. "It's very rural. It's diverse in terms of socioeconomic status," according to Nora. As for the school-community as a whole, "we are very close knit. We're like a family here. It's pretty unique," according to Nora, "we all just get to know each other from the beginning, and everyone feels comfortable." Nina seconds this. She shared how teachers who have left to teacher in another district will share with her how much they miss New Falls. "You guys have a really good community," is what they will say. Or sometimes it's more "I did not realize how close we became. We were like family," Nina commented. She reflected on those comments and said, "that's true. Because we are smaller, we do have that closeness."

Nina said there are many committees that teachers can participate with. Some revolve around school improvements while others are beautification efforts. Nora shared how the school board loves when teachers come in to showcase what they have going on 
in their classrooms. Nicole agreed, they "give us a pat on the back. They really appreciate us." Nina laughed about how small their town really is. "It takes, like, two minutes to get through town," so she sees a lot of her school-community every day.

According to Jana, the community is very involved with the school in Joanstown. "We have a very good support system from the town." She said, part of what makes it so good is the communication with the different people and businesses. "Everything is intertwined," Jacob shared, the school "has a very active and is a very big part of the community." Jacob feels like their local Lions Club and churches play an important role within their school-community. Jacob gave a great example of how connected everything is. The baseball field is owned by the school, "but I wouldn't dare call it a school field. It's the towns field...it's communal." He said the field is used for family nights on Sundays, summer recreation activities, and high school softball and baseball to name a few. The biggest event of the year in Joanstown is the Lions Club's Labor Day festival. Jacob joked that there will always be "rubs between people" no matter the size of town, but he thinks Coalsville is "a great example of everybody pulling on the rope in the same direction" because ultimately, everyone wants to see the students be successful. "We have great parent support for our kids and their education," Jacob shared. He said that he "feels very fortunate that we don't have a lot of the big issues that the bigger districts have." Jana also loves that students are able to be a part of whatever they want to. "There aren't any try outs" or obstacles like that in order to participate. Julia said most students are "rural farm kids...they spend a lot of time outside." She said that the school is "the hub of the community." 
James feels like he knows everyone. "I know all the families, parents, older siblings. Some of them I went to school with or were even in my class." He continued on to share how well-behaved students at Joanstown are. "We don't have a lot of discipline issues...We have a pretty good group of kids. The same thing for the teachers and community." He feels like teachers support each other and the community is very active in school activities. "We have great community support." James shared that most of the staff that sticks around Joanstown is from the area. He said the school cannot compete monetarily with districts near them, so that creates a majority of their turnover. He said, "I love being from a small school." Joel feels the same way. He furthered his thoughts by saying, "our community is just outstanding. It's a great support system...It's one of the reasons I think our [school] has been so successful."

\section{Why Teachers Stay}

Teachers were asked why they stayed teaching in their rural public school for so long. Two very strong responses emerged: administrative support and belonging to the community. Both of these topics look different for each individual teacher, but their responses provide insight as to what the entire school community can do in order to retain quality teachers.

Joel shared that each of the successful, long-term teachers interviewed at Joanstown all have a tie to the community. One of those teachers is James. He feels like he has been a good fit with Joanstown because it's "what I'm used to." He does not get overwhelmed by having a lot of responsibilities. "It's my home. It's the school that I love. I want it to be successful." Cooper mentioned something similar to Joel. He said some of his teachers are originally from the area, but ultimately, it is more about who is 
involved with the community now. Teachers that embrace the school-community start to "feel like family."

Julia, like many teachers, mentioned she felt like she was part of a family at her school. Nina also shared that she's "enjoyed the family feel as a school." It's all about the people. Nicole loves the people she works with. "We are such a family." It's really about having a small community to call home. Part of that family feel comes from involvement. Cooper said that "everybody comes to the ballgames and everybody comes up to you to say hi...it's an unreal community. It really is." Natalie stated her tight knit community has a very supportive parent-teacher organization. Her parents and teachers truly emulate a team. "I think that is what makes the difference."

Joel shared there are a lot of opportunities for teachers to communicate with parents and other members of the community. It is those connections that Matt will always remember fondly. "Here's an example. My mom died last December. The outpouring that I got from Marshall City School District and the community...I can't tell you what that meant to me and my family." When asked why teachers stay so long in New Falls, Natalie said, "I think it goes back to the community, the camaraderie that you have with your colleagues...Once teachers get here, they really do embrace [it]."

Mentoring made an impact on Jacob in Joanstown. He fondly spoke of the athletic director that took him under his wing when he first got there. "He and I connected in a strong way." Now he feels personally responsible to acclimate the new teachers in his building to the school-community. He wants them to "see the family aspect of the school that drew me in all those years ago. I am that steward now. I want to share that with people." Jacob was very passionate when he said, "I want them to love the school as 
much I love the school. And I hope that pours off of me. They are important for the future of that school. They're the next generation."

Nina also feels like part of her job as a seasoned teacher is to "help others out that have not been here as long." She feels like her school-community is a friendly environment. The school-community just means so much more than most realize, Mya confirmed. When asked why he thought teachers choose to stay in Joanstown, Joel said, "I think a lot of it has to do with our students and our community. I do. I think that people really enjoy the atmosphere." Melissa confirmed, "I love my team and I love the kids. I love the atmosphere of the school." Rural school districts that connect with their teachers are the ones who are most successful. When Matt asked why he's stayed all these years, his response was "they just embraced me."

Jacob, on the other hand, said, "I guess the question should be what made them embrace me?" The community helped Jacob grow into his role in Joanstown. He thinks being a coach helped him get introduced to many influential people. Jacob said that a community member once told him that "the school's gymnasium is like the front porch of the school...People want to see you on your porch...Boy, you meet so many people in the community that way." He continued on to say that if the "school ever went away, the town would go away around it. That's why they care about it so much and they embrace it so much."

Coalsville has been a good fit for Caleb. "I guess it's the relationships I've built there. I feel like I give everything to that school system." He said he does not treat it like a job, but rather a lifestyle. Melissa agreed. "It's being part of something much bigger than just being a teacher or having an impact...The intimacy at a small school just allows 
for a deeper connection" Jana continued to sum up many teachers' feelings when she stated the reason why she has stayed. "The community within the building and the community within the town." She continued on to say that she "really enjoys all the teachers and the administrators that I work with...the kids are really good, too.” The school-community as a whole "keeps me here and happy."

Having a positive outlook with students can also make a difference, according to Mya. Emma shared that she feels like Easton cares about the students. "We still have the opportunity here to teach what really matters without interference from people who do not have the students' best interests at heart." Matt had something similar to share. "I just love my job and love the kids." Emma continued on that her student's success is what keeps her around. "I had a lady from the community tell me that she was amazed at how well one of my former students was doing in college."

On the other side of participants discussion, many teachers feel like their administrators are a big reason why they stay. Melissa boldly stated that she attributes all of her success to her first principal at Marshall City. She said that having a strong, strong leader to model and show her how to be successful made the largest impact on her in terms of retention. Cara said she decided to stay in Coalsville all the years she has because when "you enjoy who you work for, it really makes you want to stay." When asked why his teachers stayed an average of 14 years, Mark said it is because they are supported. "They are supported if they want to try something new or if they want to improve." Curt agrees. He feels like he is in a situation where his administrator "cares and is trying to help me seek my success." Julia said the biggest thing for her in terms of 
retention is that she was "an administrator who's going to be on my side, be on my team."

The principal at Easton said it is important to bring people in and "treat them right." When asked to describe what that looks like, Ethan said it is simple. He gave an example about something he recently did for his staff. He said he bought them fountain drinks one afternoon just as a small thank you. He continued on to say that he just wants his “teachers to be successful and I'm going to support them. I'm going to trust that they know what they're doing...I want them to feel super comfortable with me." He said that even when tough conversations have to happen, he tries to meet teachers with empathy and compassion. "I want people to come in and think it's a good place to work...I want a good environment."

Elena, who is on the school's professional development committee, stated, "our goal [in Easton] for the year is to improve community and culture. The kind of stuff that makes everybody feel appreciated." Natalie said that they are also working on keeping morale up. Working towards a healthy building culture is noticeable. "There's a difference within the building if there's a rift between staff and administration." Cooper explained, "I feel like the students see and understand that."

When teachers are doing what is best for kids, the administration is going to "let you do your thing," according to Ethan. He proudly shared they did not have to replace anyone in Easton last year and only had to replace one person the year before due to a teacher retiring. "I think people want to work somewhere they're appreciated...Somewhere that has some structure but is also friendly, successful but not a lot of extra pressure coming from myself, the superintendent, or the board." 
If the "administration and school board are supportive of the teachers, you're going to get them to stick around," according to Matt. The stability and environment the school-community has provided is why many teachers continue to teach in their rural school. "Having strong administrators is huge," according to Elena. It creates a positive environment for teacher retention. Cara agreed, "I definitely have to say that I stayed just because of my administration. It's just a happy atmosphere."

Nora agreed things are much less stressful when you have the support of your whole community. "I just love the community. The school board is very supportive." Support seems to be something all teachers desire from their administration. She shared her principal is the reason she has stayed in New Falls for 23 years. "If I have a parent concern or a student who needs discipline, she will help me with that." Nora also discussed the importance of teachers having the tools they need to do their job. It does not matter if "they're going to send you somewhere [for professional development] or you're going to bring somebody in, [new teachers] just need support."

In some cases, schools have worked collaboratively to make their processes better each year. Elena shared that when she came to Easton, there was not a true mentoring program. She ended up joining the professional development committee and helping the others design one. They put together a handbook and select mentors who are closely aligned with the new teacher. They have tried to make everything "easy as possible" for their incoming teachers. Curt mentioned they did not have a handbook when he arrived, but he thought it would have been handy. He said he brought it to someone's attention and now Coalsville has one to give their new teachers. It contains basic information, but he believes it has been helpful in recent years. 
Ultimately, it was obvious the school-community as a whole has a large impact on retention of teachers. Everyone from students and their families, to staff on committees, to principals and superintendents, to school board members and ball game fans play a part. Cooper joked that 'I've used the word supportive like 6000 times, but I mean that's really what it boils down to." Joel summed it up well when he said everybody is a really big advocate for their school. They take pride in the work they do and work together to support one another, especially those new teachers.

\section{Keeping Teachers Satisfied}

Satisfied teachers have a lower rate of attrition. Knowing this makes it important to ask participants what made teachers satisfied. People "definitely know if [teachers] aren't satisfied," according to Cara. She, like many participants, said you hear teachers complaining when they are not satisfied. They complain about "anything and everything." Elena followed that by saying you know if people are satisfied by visiting with them. When she visits with teachers, "I hear the good and the bad. For the most part, it's good." She continued that when you have a good administrator, the "atmosphere is so positive."

For Julia, she also believes you can hear the difference between a satisfied and an unsatisfied staff. She can tell "during staff meetings and everybody comes in and is joking around and everyone is in a positive mood. You don't hear a lot of rumblings in the hallway." Nicole said something similar. In "such a small school, you just hear it...Everyone is just so close to each other." James shared he "thinks a lot of it is probably just the attitude of teachers." He said teachers who are always in a bad mood are 
the ones who do not stick around long in Joanstown. He said the interaction with kids, parents, and other teachers tells you a lot. "It's a mindset."

In Marshall City, Mark said his teachers want support more than anything. "If they don't feel like they're getting supported by the administration, they're not going to want to be here. And that's where that relationship between the administrator and teacher comes in." Mark has no doubt that being supported is going to keep his teachers satisfied. When asked if she was satisfied, Nina said she was because "I feel like I can get help if I need it. I can go to anyone."

While everyone may feel a little bit differently about what keeps teachers satisfied, Cooper believes it boils down to support. Teachers "need to feel like, at the end of the day, they can teach and do what's best, and they're going to have administrator support, no matter what." He believes his role as the principal is to "be the person that teachers can count on, that's going to be here for you."

Caleb also believes that "it all starts with administration." In order to be successful in a small school, "you have to have supportive administration." He wants someone who communicates well, will have your back if an issue arises, and allows teachers to teach. He said that some administrators want to make everything the teacher's problem. That's when teachers become unsatisfied. "A simple thank you goes a long ways." Caleb smiled when he said, "When you've got an administrator that will go out of their way to say 'man, you do a lot for me. I appreciate it.' That's worth about an extra $\$ 5000$ on my paycheck."

When administrators are supportive, Nora is most satisfied. Her administrators support her at times when she has questions or student issues. She appreciates that "I 
know I am going to get support from my principal.” Nora feels like she can freely share concerns in meetings and they are met with fresh solutions. Feeling valued just means so much to her. Teachers want to know that "their ideas matter. And that what they're doing is going to make an impact on their kids...You feel like you're going to make a difference." Natalie agreed that seeing students be successful keeps her teachers satisfied. They know they may be "the best six hours that some of these kids have each day." Julia agrees. She said you can tell the staff is satisfied when "the kids seem happy. When the staff is happy, it usually translates to them."

Nina also said she knows New Falls is a good fit for her because she is happy. "I haven't really wanted to go somewhere else." Matt feels similarly. He said the teacher retention lets you know if teachers are satisfied. In Marshall City, the people Matt is close with have super high satisfaction. They are not looking for other jobs. He often hears “there's no place like Marshall City."

Melissa knows she is satisfied because she looks forward to going to work each day. It "is a blessing that I never go to work, I go to school. And there's a really big difference in perspective in those two statements." Mya agreed. The building morale is a big piece of satisfaction for her. "Creating a community within the teachers" makes her look forward to work each day. She's built friendships that are inside and outside of school with her co-workers.

Stability is really important to the teachers in Joanstown, according to Joel. His teachers know what to "expect on a day to day basis." He believes that keeps satisfaction high in his building. Nicole likes stability specifically in what she teaches. "I think it really helps in having a say in our curriculum." She does not like when something new is 
presented to the staff without the resources to support it. She appreciates that her principal is always willing to fix things that are not working for teachers in the classroom.

With all of that being said, Jana suggested that successful teachers are not ever completely satisfied. Several teachers mentioned this to some degree. They are always looking for new opportunities to grow. Emma said, "I'm not sure there is such a thing as teacher satisfaction. If a teacher is feeling satisfied, he or she is missing something. It almost always turns into complacency." 


\section{Appendix I}

\section{Participants Setting}

Column 1: Rural School's Pseudonym

Column 2: School's 2019-2020 Enrollment

Column 3: 2016 MSIP-5 Score

Column 4: 2015 MSIP-5 Score

Column 5: 2014 MSIP-5 Score

Column 6: 2018 Average Staff Years of Experience

\begin{tabular}{|c|c|c|c|c|c|}
\hline School & Enrollment & 2016 MSIP & 2015 MSIP & 2014 MSIP & Years \\
\hline Joanstown & 213 & 95.7 & 89.9 & 90.7 & 14.6 \\
\hline New Falls & 473 & 97.1 & 98.6 & 89.3 & 12.4 \\
\hline Easton & 287 & 94.3 & 94.2 & 94.6 & 10.7 \\
\hline Coalsville & 102 & 90.6 & 96.0 & 93.5 & 15.1 \\
\hline Marshall City & 288 & 95.7 & 97.1 & 92.9 & 14.1 \\
\hline
\end{tabular}


Appendix J

\section{Participants}

Column 1: Rural School's Pseudonym

Column 2: Participant's Pseudonym

Column 3: Participant's Role

Column 4: Participant's Years in District

\begin{tabular}{|c|c|c|c|}
\hline School & Participant & Role & Years \\
\hline Coalsville & Curt & 7-12 Math Teacher & 10 \\
\hline Coalsville & Caleb & 7-12 Social Studies Teacher & 6 \\
\hline Coalsville & Cara & Special Education Teacher & 9 \\
\hline Coalsville & Cooper & Principal & 1 \\
\hline Easton & Emma & High School English Teacher & 9 \\
\hline Easton & Ethan & Principal & 24 \\
\hline Easton & Elena & High School Math and Science Teacher & 7 \\
\hline Joanstown & James & High School Ag Teacher & 10 \\
\hline Joanstown & Jana & Middle School Social Studies Teacher & 20 \\
\hline Joanstown & Jacob & High School Social Studies Teacher & 19 \\
\hline Joanstown & Julia & Title I Teacher & 11 \\
\hline Joanstown & Joel & Principal & 3 \\
\hline Marshall City & Melissa & Middle School English Teacher & 8 \\
\hline Marshall City & Matt & High School Social Studies Teacher & 14 \\
\hline Marshall City & Mark & Principal & 16 \\
\hline Marshall City & Mya & Kindergarten Teacher $^{\text {th } \text { Grade Teacher }}$ & 5 \\
\hline New Falls & Nora & $2^{\text {nd }}$ Grade Teacher & 23 \\
\hline New Falls & Nicole & $5^{\text {th }}$ Grade Teacher & 15 \\
\hline New Falls & Nina & Principal & 17 \\
\hline New Falls & Natalie & & 30 \\
\hline
\end{tabular}


Amanda Lynn Minear holds a Bachelor of Science in Middle School Math and Art Education, as well as a Master's in Education and an Educational Specialist in Educational Leadership and Policy Analysis. All degrees are from the University of Missouri. A Doctor of Education in Educational Leadership and Policy Analysis is expected from the University of Missouri in December of 2020. She has spent the last 10 years working in public education. She has been a teacher and an administrator. She is currently an administrator in Columbia Public Schools. 